
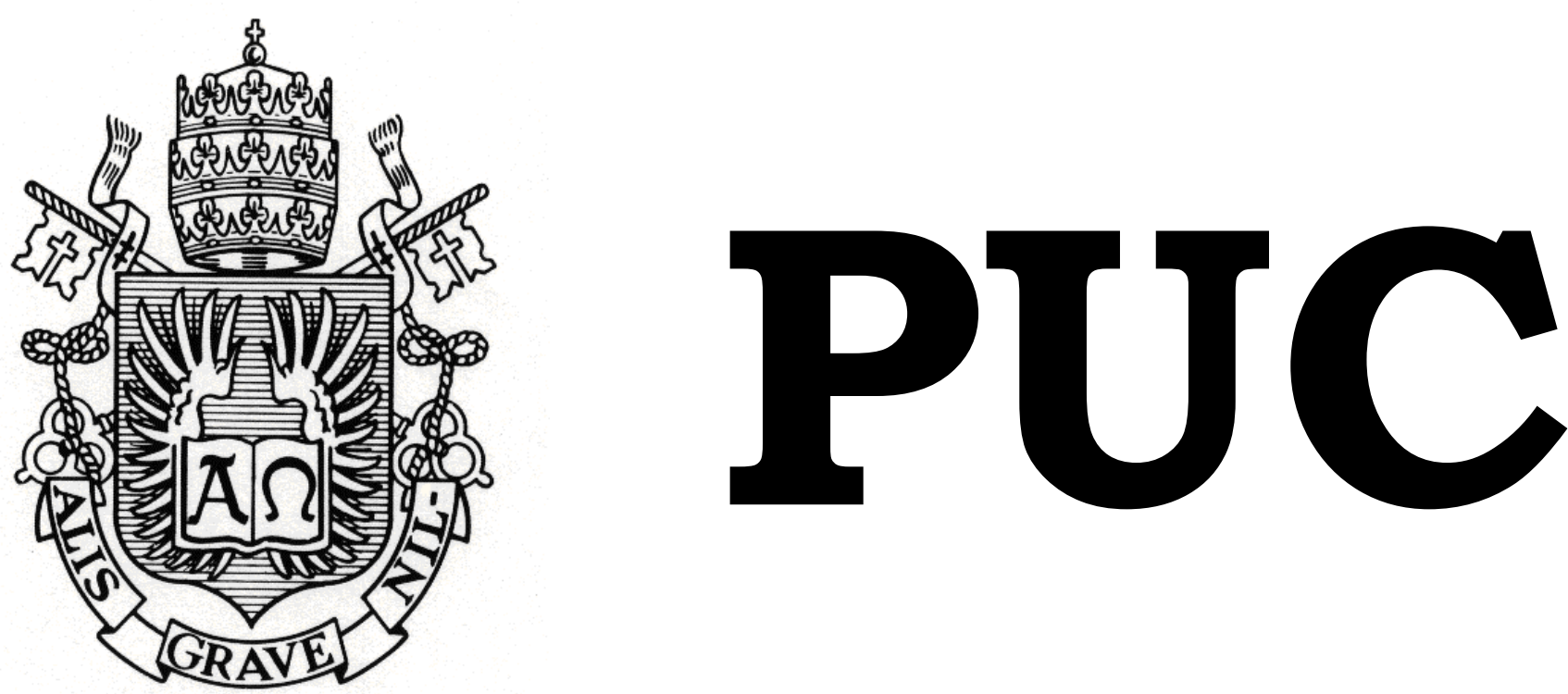

DEPARTAMENTO DE DIREITO

\title{
COMPENSAÇÃO AMBIENTAL: QUESTÕES CONTROVERTIDAS E APLICAÇÃO PRÁTICA
}

por

Michelle Mendlewicz

Orientadora: Danielle de Andrade Moreira

2013.2

PONTIFÍCIA UNIVERSIDADE CATÓLICA DO RIO DE JANEIRO

RUA MARQUÊS DE SÃO VICENTE, 225 - CEP 22453-900

RIO DE JANEIRO - BRASIL 


\title{
COMPENSAÇÃO AMBIENTAL: QUESTÕES CONTROVERTIDAS E APLICAÇÃO PRÁTICA
}

\author{
por \\ Michelle Mendlewicz
}

Monografia apresentada ao Departamento de Direito da Pontificia Universidade Católica do Rio de Janeiro (PUC-Rio) para a obtenção do Título de Bacharel em Direito.

Orientadora: Danielle de Andrade Moreira. 
Aos meus pais, Mauro e Bety, pelo apoio incondicional durante minha formação acadêmica, pela confiança depositada em mim e por serem o exemplo de esforço e determinação que são. Em especial ao meu pai, pelo incansável amor ao debate, e a minha mãe pelo carinho, atenção e cuidado sempre. A minha irmã, Nicole, pela diversão garantida mesmo nos momentos mais dificeis.

À Lia e Anna, por todo o apoio $e$ compreensão durante a elaboração deste trabalho.

À Professora e Orientadora Danielle Moreira, pelo amor e visão crítica do Direito Ambiental, pela ajuda e atenção durante esta fase, mas principalmente, pela energia e animação sempre contagiantes. 


\section{RESUMO.}

MENDLEWICZ, Michelle. Compensação Ambiental. Rio de Janeiro, 2013, xxxp. Monografia - Departamento de Direito, Pontifícia Universidade Católica do Rio de Janeiro.

O presente trabalho visa tratar do instituto da compensação ambiental prevista no art. 36 da Lei do SNUC, analisando seus fundamentamos, bem como sua extensa evolução normativa e as principais ações judiciais atualmente em tramitação no Supremo Tribunal Federal relativas ao tema. O objetivo primordial deste estudo é averiguar de que forma tais controvérsias têm representado verdadeiros entraves à aplicação prática dos recursos da compensação ambiental, comprometendo, assim, o fortalecimento do Sistema Nacional das Unidades de Conservação e, consequentemente, a promoção do meio ambiente ecologicamente equilibrado.

\section{PALAVRAS-CHAVE:}

Direito Ambiental. Compensação Ambiental. Sistema Nacional das Unidades de Conservação. 


\section{SUMÁRIO}

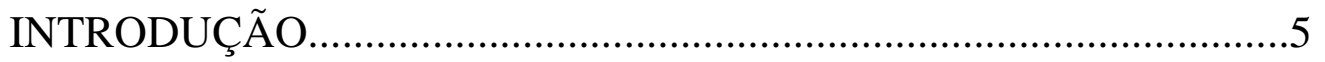

1. FUNDAMENTOS DA COMPENSAÇÃO AMBIENTAL .............8

1.1. PRINCÍPIO DA DEFESA DO MEIO AMBIENTE E A ORDEM ECONÔMICA CONSTITUCIONAL........................

1.2. PRINCÍPIO DO POLUIDOR-PAGADOR .............................12

1.3. LICENCIAMENTO AMBIENTAL......................................22

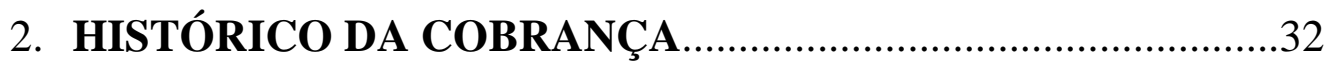

2.1. REGULAMENTAÇÃO ANTERIOR À LEI DO SNUC.......32

2.2. REGULAMENTAÇÃO POSTERIOR À LEI DO SNUC......36

3. QUESTÕES CONTROVERTIDAS............................................

3.1. PRINCIPAIS QUESTÕES ENFRENTADAS

ATUALMENTE PELO STF.................................................47

3.1.1. AÇÃO DIREITA DE INCONSTITUCIONALIDADE

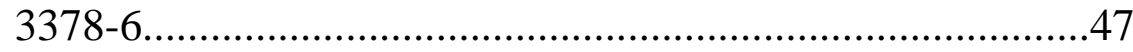

3.1.1.1. NATUREZA JURÍDICA........................50

3.1.1.2. DECISÃO DA ADI 3378-6....................57

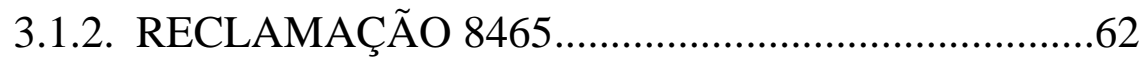

3.2. APLICAÇÃO PRÁTICA DA COMPENSAÇÃO

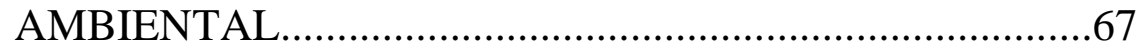

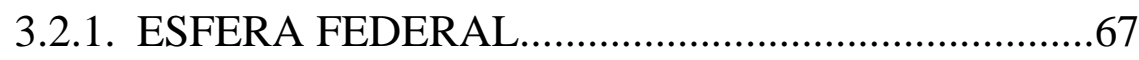

3.2.2. ESFERA ESTADUAL..............................................78

3.2.2.1. PRINCIPAIS POLÊMICAS ESTADUAIS.............................................................78

3.2.2.2. O CASO DO FUNBIO.............................84

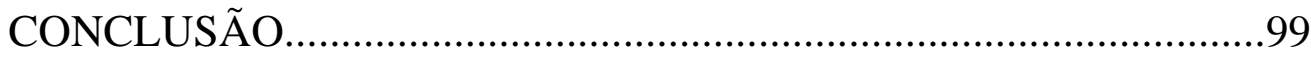

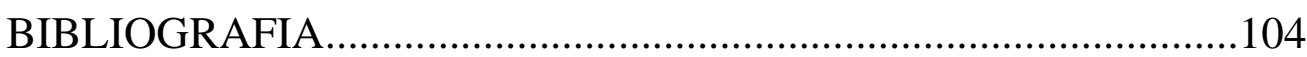




\section{Introdução}

A vida moderna tem gerado uma série de consequências e danos ambientais, como a emissão de poluentes no ar, a contaminação do solo, o vazamento de produtos nocivos no mar, entre outros. Todos esses acontecimentos são consequências da apropriação de espaços e utilização de recursos ambientais pelos seres humanos. Diante deste cenário, tornou-se papel do Direito regular as atividades do homem que afetam o meio ambiente. É justamente neste contexto que se configuram as medidas compensatórias e, mais especificamente, o instituto da compensação ambiental, visando um reequilibro das relações, de modo que o poluidor seja obrigado a internalizar em seu processo produtivo os impactos ambientais que podem ser gerados por sua atividade, de forma que ele não lucre com tais danos, enquanto a sociedade arca integralmente com o prejuízo ambiental criado.

Neste sentido, o presente trabalho trata da compensação ambiental prevista na Lei 9.985/2000, que instituiu o Sistema Nacional de Unidades de Conservação (SNUC). É sabido que as unidades de conservação, por serem espaços territoriais especialmente protegidos, são essenciais para a promoção e conservação da biodiversidade, bem como para o uso sustentável dos recursos naturais, sendo apontadas inclusive como uma das mais efetivas formas de proteção ambiental.

Por meio deste instituto, os empreendedores de atividades que tenham o potencial de causar significativo dano ao meio ambiente, são obrigados a disponibilizar recursos financeiros para serem aplicados justamente na manutenção e criação de unidades de conservação, o que demonstra claramente seu alto grau de importância.

Em que pese sua relevância na promoção do meio ambiente ecologicamente equilibrado, a compensação ambiental, desde a sua criação no ordenamento jurídico brasileiro e até os dias de hoje, vem gerando diversas polêmicas, tanto normativas quanto jurisprudenciais, que acabaram por representar verdadeiro entrave à sua aplicação. 
Neste contexto, o presente estudo busca verificar quais são os principais questionamentos ocorrendo atualmente e de que forma estão comprometendo sua aplicação de forma justa e efetiva em busca do fortalecimento do SNUC e em respeito ao meio ambiente e à coletividade.

Dentro desta proposta, o trabalho foi dividido em três capítulos. O primeiro capítulo trata dos fundamentos da compensação ambiental, abordando, primeiramente, o princípio da defesa do meio ambiente em busca de uma ordem econômica na qual haja um equilíbrio entre a proteção ambiental e o desenvolvimento econômico tendo como objetivo a justiça social. O segundo princípio analisado é o princípio do poluidor-pagador, estabelecendo a obrigação do empreendedor de proceder à internalização das externalidades ambientais negativas causadas por sua atividade, evitando a chamada privatização de lucros e socialização de perdas. $\mathrm{O}$ terceiro fundamento abordado é o licenciamento ambiental, procedimento no qual se efetiva esta obrigação, que é condição indispensável para a outorga das licenças ambientais. A compensação ambiental busca justamente a prevenção de danos inevitáveis, inafastáveis, mas toleráveis social e ecologicamente, que são previstos no EIA/RIMA realizado no processo licenciatório.

O segundo capítulo, por sua vez, cuida do histórico da cobrança da compensação ambiental, dividindo-se em dois momentos principais, tendo como divisor de águas a promulgação da Lei do SNUC. Anteriormente à existência da referida lei, a regulamentação da compensação ambiental se deu pela Resolução CONAMA 10/1987 e a Resolução CONAMA 02/1996. Posteriormente, foi introduzida no ordenamento jurídico a Lei do SNUC, que passou a prever este instituto em seu art. 36 e seus parágrafos. Objetivando sua regulamentação, foi editado o Decreto 4.340/2002, alterado pelo Decreto 5.566/2005. Um ano depois, o CONAMA editou a Resolução 371/2006, trazendo, mais uma vez, novidades em relação ao tema. Note-se que, além desta evolução normativa, este capítulo também trata da Portaria MMA 416/2010, que instituiu a Câmara Federal de 
Compensação Ambiental (CFCA), e da Portaria Conjunta MMA/IBAMA/ICMBio 225/2011, que estabeleceu o Comitê de Compensação Ambiental Federal (CCAF).

Já o terceiro e último capítulo trata das questões controvertidas sobre a compensação ambiental, sendo esta análise dividida em dois blocos. $\mathrm{O}$ primeiro deles trata das principais questões atualmente em discussão no Supremo Tribunal Federal (STF) no âmbito da ADI 3378, que questionou a constitucionalidade deste instituto, analisando diversas polêmicas como sua natureza jurídica (seria de tributo/preço público ou responsabilidade civil por danos ambientais futuros?) e sua forma de cálculo, restando pendente a aplicação da decisão desta ação tendo em vista o fato de que os Embargos de Declaração opostos permanecem aguardando julgamento. Além da referida ADI, este item aborda ainda a Reclamação 8465, ajuizada após a edição do Decreto Federal 6848/2009, alegando que a referida norma teria contrariado o entendimento manifestado pelo STF no julgamento da ADI.

Em um segundo momento passa-se à análise da aplicação prática da compensação ambiental, tanto na esfera federal, quanto estadual. Em âmbito federal tem-se como base o Acórdão 1853/2013-TCU-Plenário que demonstra avaliação operacional promovida sobre a aplicação e fiscalização dos recursos da compensação ambiental, com destaque para a aplicação dos valores nos últimos dez anos, bem como avaliando a eficiência e eficácia dos programas de governos por ele assistidos.

Em âmbito estadual são enfrentadas algumas questões pontuais como a falta de unanimidade dos Estados-Membros quanto à base de cálculo da compensação ambiental, que poderia gerar uma possível inconstitucionalidade desses atos normativos estaduais por ampliarem o escopo das normas federais. Outra questão ventilada é a possibilidade de configuração de bis in idem com a cobrança da chamada compensação ambiental social, conjuntamente com a compensação ambiental objeto do presente estudo. Por fim, este capítulo analisa ainda a Ação Civil Pública recentemente ajuizada pelo Ministério Público do Estado do Rio de Janeiro 
em face do Fundo Brasileiro para a Biodiversidade (FUNBIO), que atualmente exerce a gestão de recursos para a criação e manutenção de unidades de conservação no Estado do Rio de Janeiro.

\section{Fundamentos da Compensação Ambiental}

\subsection{Princípio da defesa do meio ambiente e a ordem econômica constitucional}

O desenvolvimento social e tecnológico que vivenciamos ao longo da história trouxe, indubitavelmente, grandes avanços para a humanidade. Contudo, foi preciso pagar um preço pelo "progresso" do qual nos beneficiamos atualmente. Juntamente com tantas descobertas e crescimentos, o meio ambiente foi e ainda é, muitas vezes, deixado de lado. Esta evolução acabou por ensejar a apropriação e utilização dos espaços e recursos ambientais pelos seres humanos. Tal apropriação do meio ambiente difere de acordo com cada sociedade e cada período histórico, mas, de toda forma, representa hoje um tema de suma importância, qual seja: a problemática ambiental nas sociedades contemporâneas e as possibilidades e limites do direito em regular as relações humanas na apropriação de espaços e utilização dos recursos ambientais. ${ }^{1}$

É tamanha a importância conferida a este tema que a Constituição Federal (CRFB/1988), além de recepcionar a Lei 6.938/1981, que instituiu a Política Nacional do Meio Ambiente (PNMA), também estabeleceu entre seus princípios a necessidade de compatibilizar o desenvolvimento social com a preservação do meio ambiente, instituindo o direito ao meio ambiente ecologicamente equilibrado, em seu art. $225^{2}$. Direito este fundamental e de todos, apesar de não estar incluindo no capítulo dos

\footnotetext{
${ }^{1}$ FERREIRA, Gabriel; SILVA, Solange. Análise dos Fundamentos da Compensação Ambiental: A Responsabilidade Civil Ex Ante no Direito Brasileiro: Revista de Informação Legislativa. Brasília, n. 175, p. 125 - 136, jul./set. 2007, n. 175, p. 125 - 136, jul./set. 2007. p. 126.

${ }^{2}$ Art. 225 da CRFB/1988: Todos têm direito ao meio ambiente ecologicamente equilibrado, bem de uso comum do povo e essencial à sadia qualidade de vida, impondo-se ao Poder Público e à coletividade o dever de defendê-lo e preservá-lo para as presentes e futuras gerações.
} 
direitos individuais e coletivos, ${ }^{3}$ incumbindo ao Poder Público e à coletividade o dever de defendê-lo e preservá-lo para as presentes e futuras gerações. $^{4}$

Trata-se de direito simultaneamente individual e social, pois do direito de fruição do meio ambiente ecologicamente equilibrado não advém nenhuma prerrogativa privada. Seu caráter jurídico é de um bem de uso comum do povo, e por isso, a realização individual deste direito fundamental está intrinsecamente ligada à sua realização social. ${ }^{5}$

Desta forma, o direito exposto pelo art. 225 da CRFB/1988 está sempre associado à coletividade. Mesmo que utilizado de forma privada e individual, as consequências daquela conduta atingem toda a sociedade, posto tratar-se de um direito de todos. Consequentemente,

uma vez compreendido que recurso natural é base da produção social, independentemente do lugar que ocupa no processo produtivo, a modificação do conjunto destes recursos, bem como de sua forma de apreensão e trabalho na sociedade, atinge toda esfera da sociedade. Isto posto, a proteção dos recursos naturais e do meio ambiente passa a ser empreendida dentro de um sentimento de solidariedade insofismável. ${ }^{6}$

A utilização dos recursos ambientais, portanto, deve ser pensada de forma coletiva, já que atinge a sociedade como um todo.

Além do meio ambiente ecologicamente equilibrado, a CRFB/1988 também concedeu significativa importância para o desenvolvimento econômico e estabeleceu, em seu art. 170, VI, $^{7}$ que a defesa do meio ambiente é um dos princípios gerais da atividade econômica, tendo como

\footnotetext{
${ }^{3}$ DERANI, Cristiane. Direito Ambiental Econômico. $3^{\mathrm{a}}$ ed. São Paulo: Editora Saraiva, 2008. p. 245.

${ }^{4}$ FERREIRA, Gabriel; SILVA, Solange. Análise dos Fundamentos da Compensação Ambiental: A Responsabilidade Civil Ex Ante no Direito Brasileiro: Revista de Informação Legislativa. Brasília, n. 175, p. 125 - 136, jul./set. 2007, p. 126.

${ }^{5}$ DERANI, Cristiane. Op. Cit., p. 245.

${ }^{6}$ Ibid. p. 249.

${ }^{7}$ Art. 170 da CRFB/1988: A ordem econômica, fundada na valorização do trabalho humano e na livre iniciativa, tem por fim assegurar a todos existência digna, conforme os ditames da justiça social, observados os seguintes princípios:

(...)

VI - defesa do meio ambiente, inclusive mediante tratamento diferenciado conforme o impacto ambiental dos produtos e serviços e de seus processos de elaboração e prestação.
} 
objetivo assegurar a todos uma existência digna, conforme os ditames da justiça social.

Trata-se, pois, do princípio da defesa do meio ambiente, que dispõe que a ordem econômica brasileira deve observar a defesa do meio ambiente, buscando um equilíbrio entre a manutenção do meio ambiente ecologicamente equilibrado e a necessidade do desenvolvimento econômico.

Importante ressaltar que há um inter-relacionamento dos mencionados artigos 225 e 170 da CRFB/1988, mais especificamente, entre os elementos presentes nestas normas. Segundo Cristiane Derani,

\begin{abstract}
Não se pode pensar em desenvolvimento da atividade econômica sem o uso adequado dos recursos naturais, posto que esta atividade é dependente do uso da natureza, para sintetizar de maneira mais elementar. Destarte, a elaboração de políticas visando ao desenvolvimento econômico sustentável, razoavelmente garantido das crises cíclicas, está diretamente relacionada à manutenção do fato natureza da produção (defesa do meio ambiente), na mesma razão da proteção do fator capital (ordem econômica fundada na livre iniciativa) e da manutenção do fator trabalho (ordem econômica fundada na valorização do trabalho humano). A consideração conjunta destes três fatores garante a possibilidade de atingir os fins colimados pela ordem econômica constitucional: assegurar a todos existência digna, conforme os ditames da justiça social. É o que dispõe textualmente o caput do art. $170 .^{8}$
\end{abstract}

Quer-se dizer, portanto, que de nada adianta pensar na ordem econômica e seu desenvolvimento sem considerar o meio ambiente e vice e versa. Para que os objetivos traçados pela Carta Magna sejam alcançados é imprescindível que tais elementos sejam contemplados em conjunto.

Nessa perspectiva, fala-se ainda que emana da CRFB/1988 o princípio conservacionista. Ou seja,

(...) na adoção de técnicas e instrumentos que garantam a integridade do bem protegido, preceito necessário para a efetividade do direito ao meio ambiente, primando por sua manutenção ou recuperação, nos casos de perda da qualidade ambiental. ${ }^{9}$

\footnotetext{
${ }^{8}$ DERANI, Cristiane. Op Cit., p. 228-229.

${ }^{9}$ FERREIRA, Gabriel; SILVA, Solange. Op. Cit., p. 127.
} 
A ideia é, portanto, conservar o meio ambiente, visando manter o bem protegido, revertendo seus serviços e benefícios em favor da humanidade, sempre com uma visão prospectiva, voltada para a proteção das gerações futuras.

Desta forma, o mencionado princípio está intrinsecamente ligado ao princípio da sustentabilidade, baseado na viabilidade econômica, prudência ecológica e justiça social. ${ }^{10}$ Como bem explicou Solange Teles da Silva e Gabriel Luis Bonara Vidrih Ferreira: ${ }^{11}$

\begin{abstract}
É justamente em matéria de estratégias de desenvolvimento endógenas que se busca aqui realizar uma reflexão sobre o papel do direito e, particularmente, dos objetivos da responsabilidade civil ambiental, entre os quais se destacam a prevenção de comportamentos anti-sociais, como também a justa distribuição do ônus e de compensar os riscos e reparar os danos ambientais. (...) Ademais, surge igualmente como efeito preventivo em uma relação jurídica que envolve interesses difusos a compensação ambiental como forma de evitar o dano e também controlar os riscos e readequar o equilíbrio nas relações jurídicas ao estabelecer limites à socialização dos riscos.
\end{abstract}

Surge neste contexto, então, a compensação ambiental. Isto porque a ideia de compensar pelos danos causados ao meio ambiente está atrelada a busca pela manutenção do meio ambiente ecologicamente equilibrado e uma sadia qualidade de vida a todos, ao mesmo tempo em que ocorre o desenvolvimento econômico. Neste sentido, a expressão compensação representa a busca pelo equilíbrio, com o intuito de

(...) restabelecer a ordem social, quer dizer, a ordem pública ambiental. Trata-se de mecanismo preventivo-distributivo que resguarda, por um lado, o equilíbrio das relações jurídicas e evita a socialização dos danos e riscos de danos, impondo àquele que se apresenta como agente causador de um risco de dano ou evento lesivo a obrigação de recompensar, de restaurar a situação ao seu estado anterior ou indenizar o respectivo valor do prejuízo. ${ }^{12}$

Desta forma, a compensação ambiental significa um grande benefício à política ambiental, pois antecipa a reparação do dano que

\footnotetext{
${ }^{10}$ Ibid. p. 128.

${ }^{11}$ Ibid.

${ }^{12}$ Ibid. p 130.
} 
poderá ocorrer em breve, melhorando as condições do meio ambiente antes mesmo que elas se deteriorem. ${ }^{13}$

\subsection{Princípio do poluidor-pagador ${ }^{14}$}

Além dos princípios expostos acima, tem-se ainda o princípio do poluidor-pagador como um dos mais importantes postulados do Direito Ambiental, segundo o qual o empreendedor fica obrigado a proceder à internalização dos custos de sua atividade, suportando a diferença entre o custo social e o custo privado. ${ }^{15}$

Fato é que as atividades econômicas geram externalidades positivas e negativas. São consideradas externalidades quando não estão incluídos no preço do bem os ganhos e as perdas sociais resultantes da produção ou consumo. Isto ocorre, pois tal efeito positivo ou negativo é de difícil

\footnotetext{
${ }^{13}$ BECHARA, Erika. Licenciamento e Compensação Ambiental na Lei do Sistema Nacional das Unidades de Conservação (SNUC). São Paulo: Editora Atlas, 2009. p. 214.

${ }^{14}$ Verifica-se na doutrina separação do princípio do poluidor-pagador e do princípio do usuáriopagador. A distinção estaria no fato de o primeiro estar relacionado à manutenção da qualidade do meio ambiente, enquanto o segundo estaria relacionado à utilização racional dos recursos ambientais de forma a manter sua quantidade em níveis razoáveis. Alguns doutrinadores, como Marcelo Abelha Rodrigues, identificam o princípio do usuário-pagador como mais abrangente que o poluidor-pagador e esclarecem que pode ser feita esta diferenciação para fins didáticos. Segundo o autor o princípio do poluidor-pagador "diz respeito à proteção da qualidade do bem ambiental, mediante a verificação prévia da possibilidade ou não de internalização dos custos ambientais no preço do produto, até um patamar que não justifique economicamente a sua produção, ou que estimule a promoção ou adoção de tecnologias limpas que não degradem a qualidade ambiental. Já a segunda expressão - princípio do usuário pagador - diferentemente do poluidor-pagador, que é voltado para a qualidade do meio ambiente (bastante aplicado em regiões com abundância de recursos), visa proteger a quantidade dos bens ambientais, estabelecendo uma consciência ambiental de uso racional dos mesmos, permitindo uma socialização justa e igualitária de seu uso".

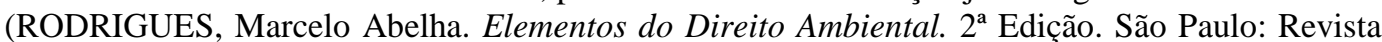
dos Tribunais, 2005, p. 226). Para os fins do presente trabalho, adotou-se a tese mais abrangente, em conformidade com o entendimento de Danielle de Andrade Moreira, de que o princípio do poluidor-pagador está "relacionado ao uso de recursos ambientais (o que nada mais é do que uma atividade potencialmente poluidora) e à efetiva ou potencial deterioração da qualidade do meio ambiente. Para fundamentar este tratamento, parte-se das também abrangentes definições de meio ambiente, degradação da qualidade ambiental e poluição, constantes da Lei da Política Nacional do Meio Ambiente (Lei n ${ }^{\circ} 6.938 / 1981$, art. $3^{\circ}$, I, II, III)". (MOREIRA, Danielle de Andrade. Princípio do Poluidor Pagador: Origens, Evolução e Alcance. In: SAMPAIO, Rômulo; LEAL, Guilherme; REIS, Antonio (Org.). Tópicos de Direito Ambiental: 30 anos da Política Nacional do Meio Ambiente. Rio de Janeiro: Editora Lumen Juris, 2011. p. 41).

${ }^{15}$ CAPPELLI, Silvia. Compensação Ambiental do Sistema Nacional de Unidades de Conservação: Considerações Pós-Decisção do STF na ADIn 3.378. In: MARQUES, Claudia; MEDAUAR, Odete; SILVA; Solange (Org.) O novo direito administrativo, ambiental e urbanístico: estudos em homenagem à Jacqueline Morand-Deviller. São Paulo: Editora Revista dos Tribunais, 2010. p. 323.
} 
mensuração. Veja-se, neste sentido, a explanação de Antonio Herman

Benjamin, ${ }^{16}$ segundo o qual:

Externalidades, em sede ambiental, são os custos sociais do processo de desenvolvimento e que, só recentemente, através do princípio poluidor-pagador, passaram a ser computados - já que exigíveis - no preço final de produtos e serviços. Diz-se, assim, que esses custos são internalizados.

(...) As externalidades nem sempre são de fácil cálculo. Primeiro porque são múltiplas as consequências de uma única ação poluidora (despesas médicas, limpeza, pintura, danos em materiais, em plantações e em rebanhos, queda do turismo e efeitos de longo prazo). Segundo porque danos morais - o desconforto humano, p. ex. — não são computáveis dessa maneira.

Diante deste cenário, percebe-se que para que o bem colocado no mercado tenha um preço correto e justo é necessário contabilizar todos os ganhos sociais advindos do consumo, bem como todas as perdas sociais adquiridas com sua produção. Caso contrário,

Não se agindo dessa forma, internalizando os custos, certamente que o produtor de um bem (aço em uma siderúrgica, por exemplo) terá um produto colocado no mercado que não será por todos adquirido, mas cujo custo social será suportado, inclusive, por quem não consumiu ou nunca irá consumir o referido produto.

Sob outra ótica, poderia se dizer que há um enriquecimento do produtor às custas de um efeito negativo suportado pela sociedade, já que não teria sido colocado no custo do seu produto esse desgaste suportado pela sociedade. ${ }^{17}$

Surge então, neste contexto, a expressão privatização de lucros $e$ socialização das perdas, explicada a seguir por Cristiane Derani: ${ }^{18}$

Durante o processo produtivo, além do produto a ser comercializado, são produzidas "externalidades negativas". São chamadas externalidades porque, embora resultantes da produção, são recebidas pela coletividade, ao contrário do lucro, que é percebido pelo produtor privado. Daí a expressão "privatização de lucros e socialização de perdas", quando identificadas as externalidades negativas. Com a aplicação do princípio do poluidor-pagador, procura-se corrigir este custo adicionado à sociedade, impondo-se a sua internalização. Por isso, este princípio também é conhecido como princípio da responsabilidade (Verantwortungsprinzip).

16 BEJAMIN, Antonio Herman. O Princípio do Poluidor-Pagador e a Reparação do Dano Ambiental. p. 6. Disponível em: http://bdjur.stj.jus.br/xmlui/handle/2011/8692. Acesso em 05.09.2013.

${ }^{17}$ RODRIGUES, Marcelo Abelha. Elementos de Direito Ambiental. $2^{\mathrm{a}}$ ed. São Paulo: Editora Revista dos Tribunais, 2005. p. 193.

${ }^{18}$ DERANI, Cristiane. Op. Cit., p. 143. 
Neste sentido, o princípio do poluidor-pagador se preocupa justamente com as externalidades negativas, ou seja, resultados danosos ao meio ambiente que a coletividade acaba por suportar, mesmo não tendo the dado causa, já que o verdadeiro causador não as internalizou em seu processo produtivo. Nas palavras de Erika Bechara: ${ }^{19}$ onde está a justiça dessa situação em que aquele que deu causa à externalidade negativa não responde por ela, mas sim terceiros? Simplesmente não está em lugar algum.

Sendo assim, este princípio, que engloba o princípio da prevenção, precaução e responsabilização das condutas lesivas ao meio ambiente, determina a internalização das externalidades ambientais negativas, imputando ao poluidor todos os custos ambientais decorrentes do funcionamento de sua atividade. ${ }^{20}$

É necessário não se deixar levar pelo nome imputado ao presente princípio, acreditando representar uma permissão para poluir mediante contraprestação. Como bem ressalta Marcelo Abelha Rodrigues ${ }^{21}$,

(...) É importante que fique claro que o axioma poluidor/usuário-pagador não pode ser interpretado ao pé da letra, tendo em vista que não traduz a ideia de "pagar para poluir" ou de "pagar pelo uso", especialmente também porque o seu alcance é absurdamente mais amplo do que a noção meramente repressiva que possui. Muitas vezes tomado como "pago para poder poluir", o princípio do poluidor pagador passa muito longe desse sentido, não só porque o custo ambiental não encontra valoração pecuniária correspondente, mas também porque a ninguém poderia ser dada a possibilidade de comprar o direito de poluir, beneficiando-se do bem ambiental em detrimento da coletividade que dele é titular.

Édis Milaré ${ }^{22}$ também se posiciona no mesmo sentido como se vê no trecho destacado a seguir:

O princípio não objetiva, por certo, tolerar a poluição mediante um preço, nem se limita apenas a compensar os danos causados, mas sim, precisamente, evitar o dano ao ambiente. Nesta linha, o pagamento pelo lançamento de efluente, por exemplo, não alforria condutas inconsequentes, de modo a ensejar o descarte de

\footnotetext{
${ }^{19}$ BECHARA, Erika. Op. Cit., p. 33.

${ }^{20}$ MOREIRA, Danielle de Andrade. Responsabilidade Ambiental Pós-Consumo: Prevenção e Reparação de Danos à Luz dos Princípio do Poluidor-Pagador. p. 63. No prelo.

${ }^{21}$ RODRIGUES, Marcelo Abelha. Elementos de Direito Ambiental. Op Cit. p. 190.

${ }^{22}$ MILARÉ, Édis. Direito do Ambiente. $8^{a}$ Edição. São Paulo: Revista dos Tribunais, 2013. p. 268.
} 
resíduos fora dos padrões e das normas ambientais. A cobrança só pode ser efetuada sobre o que tenha respaldo na lei, pena de se admitir o direito de poluir. Trata-se do princípio poluidor-pagador (poluiu, paga os danos), e não pagadorpoluidor (pagou, então pode poluir). Esta colocação gramatical não deixa margem a equívocos ou ambiguidades na interpretação do princípio.

Contudo, é importante levar em conta que a internalização dos custos ambientais no processo produtivo não pode ser tal de forma a inviabilizar o exercício da atividade,

Assim, as leis que dispõem sobre a internalização dos custos ambientais concentram-se geralmente até o limite em que não se sobrecarrega a valor dos custos da produção, evidentemente porque, levando a aplicação do princípio do poluidor-pagador até os seus limites, chegar-se-ia à paralisação da dinâmica do mercado, por uma elevação de preços impossível de ser absorvida nas relações de troca. $^{23}$

Parece então que o objetivo do referido princípio não é impedir o desenvolvimento da economia de determinado setor produtivo, mas sim, fazer com que o empreendedor internalize em sua produção os custos dos impactos ambientais inevitáveis que serão gerados pelo exercício daquela atividade, de forma que aquele que usufrua do bônus arque também com o ônus.

Diante do exposto, pode-se constatar que o princípio do poluidorpagador está intrinsecamente ligado às regras de mercado e à economia. De fato, originalmente, este princípio nasceu de tais regras, como uma teoria econômica. Contudo, com o passar do tempo, o direito internacional acabou fazendo com que o mesmo se tornasse um princípio eminentemente jurídico. Segundo, Antonio Herman Benjamin, ${ }^{24}$

Se é certo que o princípio poluidor-pagador encontra seus fundamentos principais na teoria econômica, é através do Direito, particularmente do Direito Ambiental, que passa a integrar a ordem jurídica e, a partir daí, se torna exigível de todos. É que cabe ao Direito Ambiental responsabilizar-se, no plano da formulação de normas jurídicas, por esta problemática da internalização dos custos sociais do desenvolvimento, aportando os instrumentos adequados de implementação, viabilizando, assim, os critérios recomendados pela Economia.

\footnotetext{
${ }^{23}$ DERANI, Cristiane. Op. Cit., p. 144.

${ }^{24}$ BEJAMIN, Antonio Herman. Op. Cit., p. 6.
} 
A primeira referência que se tem do princípio em comento surgiu na Recomendação sobre Princípios Relacionados aos Aspectos Econômicos Internacionais das Políticas Ambientais, do Conselho da Organização para a Cooperação e Desenvolvimento Econômico (OCDE), de 1972. Neste momento, as nações começaram a se preocupar efetivamente com os problemas ambientais, reconhecendo a necessidade de que os custos relacionados à prevenção e ao controle da poluição fossem devidamente alocados na cadeia de produção e consumo, de forma que não fossem arcados de modo exclusivo pelo governo e, consequentemente, por toda a sociedade. $^{25}$

Neste momento, o referido princípio baseava-se em uma teoria fundamentalmente econômica, objetivando promover a adequada alocação de custos e evitando a falha de mercado em virtude da existência de externalidades, ${ }^{26}$ como pode ser constatado pela definição da própria Recomendação ${ }^{27}$ que se segue:

1. Recursos ambientais geralmente são limitados e seu uso em atividades de produção e consumo pode levar à sua deterioração. Quando o custo desta deterioração não é adequadamente considerado no sistema de preços, o mercado deixa de refletir a escassez de tais recursos em âmbito nacional e internacional. Medidas públicas são então necessárias para reduzir a poluição e

\footnotetext{
${ }^{25}$ MOREIRA, Danielle de Andrade. Princípio do Poluidor Pagador: Origens, Evolução e Alcance. In: SAMPAIO, Rômulo; LEAL, Guilherme; REIS, Antonio (Org.). Tópicos de Direito Ambiental: 30 anos da Política Nacional do Meio Ambiente. Rio de Janeiro: Editora Lumen Juris, 2011. p. 3. ${ }^{26}$ Ibid.

${ }^{27}$ Tradução livre: "2. Environmental resources are in general limited and their use in production and consumption activities may lead to their deterioration. When the cost of this deterioration is not adequately taken into account in the price system, the market fails to reflect the scarcity of such resources both at the national and international levels. Public measures are thus necessary to reduce pollution and to reach a better allocation of resources by ensuring that prices of goods depending on the quality and/or quantity of environmental resources reflect more closely their relative scarcity and that economic agents concerned react accordingly.

3. (...)

4. The principle to be used for allocating costs of pollution prevention and control measures to encourage rational use of scarce environmental resources and to avoid distortions in international trade and investment is the so-called "Polluter-Pays Principle". This principle means that the polluter should bear the expenses of carrying out the above-mentioned measures decided by public authorities to ensure that the environment is in an acceptable state. In other words, the cost of these measures should be reflected in the cost of goods and services which cause pollution in production and/or consumption. Such measures should not be accompanied by subsidies that would create significant distortions in international trade and investment."

Disponível

em:

http://acts.oecd.org/Instruments/ShowInstrumentView.aspx? InstrumentID=4\&InstrumentPID=255 \&Lang=en\&Book=False. Acesso em 15.08.2013.
} 
para atingir uma melhor alocação de recursos, assegurando que os preços dos bens, dependendo da qualidade e/ou quantidade de recursos ambientais, reflita de forma mais próxima sua escassez relativa e que agentes econômicos envolvidos reajam de acordo.
2. (...)
3. O princípio a ser utilizado para a alocação de custos de prevenção de poluição e medidas de controle para encorajar o uso racional de recursos ambientais escassos e para evitar distorções no investimento e comércio internacional é o chamado "Princípio do Poluidor-Pagador". Este princípio significa que o poluidor deveria arcar com os custos das medidas mencionadas acima, decididas pelas autoridades públicas, para assegurar que o meio ambiente esteja em um estado aceitável. Em outras palavras, o custo destas medidas deveria ser refletido no preço dos produtos e serviços que causem poluição em sua produção e/ou consumo. Tais medidas não deveriam ser acompanhadas de subsídios que iriam criar distorções significativas no investimento e comércio internacional. (grifos meus).

Note-se que em sua primeira versão, o princípio do poluidor-pagador apenas garantia a internalização parcial dos custos ambientais. Neste momento, não se destinava a obrigar o poluidor a assumir todas as consequências de seus atos. Silvia Capelli ${ }^{28}$ ao citar Agathe Van Lang explica que:

O fundamento para a adoção do princípio era a proibição dos subsídios estatais visando a financiar os investimentos antipoluição. Os poluidores deveriam suportar sozinhos os custos de prevenção e de luta contra a poluição, o que excluiria as subvenções e as ajudas fiscais que mascaram a concorrência entre as empresas que delas se beneficiam e as outras.

O referido princípio também foi abordado em outras recomendações da OCDE. $^{29}$ Em 1974, na Recomendação do Conselho sobre a Implementação do Princípio do Poluidor-Pagador, o mesmo foi reafirmando como princípio fundamental para os Estados-Membros. Já, nas orientações da OCDE relacionadas às políticas de gestão de resíduos, de 1976, e de poluição acidental, de 1989, observa-se a aplicação deste princípio na

\footnotetext{
${ }^{28}$ CAPPELLI, Silvia. Op. Cit., p. 323.

${ }^{29}$ Tais como: (i) Recomendação do Conselho sobre a Implementação do Princípio do PoluidorPagador, de 1974;29 (ii) Recomendação do Conselho sobre Gestão Ampla de Resíduos, de 1976;29 (iii) Recomendação do Conselho sobre a Aplicação do Princípio do Poluidor-Pagador à Poluição Acidental, de 1989;29 (iv) Recomendação do Conselho sobre o Uso de Instrumentos Econômicos na Política Ambiental, de 1991;29 e (v) Recomendação sobre a Utilização de Instrumentos Econômicos na Promoção e Conservação da Biodiversidade, de 2004.
} 
adoção de medidas voltadas para a destinação ambientalmente adequada de resíduos e até mesmo para a reparação de determinados danos. ${ }^{30}$

A recomendação relativa à aplicação específica do princípio do poluidor-pagador nos casos de poluição acidental inovou ao revelar que o mesmo não teria apenas uma faceta preventiva, mas também reparadora, como se vê no trecho a seguir:

11. Outra aplicação específica do Princípio do Poluidor-Pagador consiste em cobrar, em conformidade com as leis domésticas, o custo razoável de medidas de controle de poluição decididas pelas autoridades devido à poluição gerada por acidentes na operação de instalações perigosas. Tais medidas tomadas sem atraso pelo operador ou, quando necessário, pelas autoridades teriam como objetivo evitar prontamente que o dano ambiental se espalhasse e limitariam o lançamento de substâncias perigosas (por exemplo, eliminando emissões na planta, erguendo barreiras flutuantes em um rio), a poluição em si (por exemplo, pela limpeza ou descontaminação), ou seus efeitos ecológicos (por exemplo, ao reabilitar um meio ambiente poluído). ${ }^{31}$

Sendo assim, sua faceta preventiva buscaria a sensibilização sobre o custo dos danos relacionados ao comportamento de produção e de consumo, visando reduzir, inovar e modificar os padrões de consumo, enquanto sua faceta reparadora, buscaria justamente a obrigação de reparar o dano gerado. Neste sentido, Silvia Cappeli ${ }^{32}$ ao citar Agathe Van Lang, novamente, explica que:

O princípio do poluidor-pagador garantiria a reparação integral dos danos ambientais porque a fixação de patamares de emissão de poluentes permite tolerar a degradação do meio ambiente dentro de limites determinados. As regras de responsabilidade podem, dessa forma, se apoiar sobre o princípio do poluidorpagador, fazendo com que o autor da poluição pague pelo custo dos danos resultantes de sua atividade.

\footnotetext{
${ }^{30}$ MOREIRA, Danielle de Andrade. Op. Cit., p. 33.

${ }^{31}$ Tradução livre: "11. A further specific application of the Polluter-Pays Principle consists in charging, in conformity with domestic law, the cost of reasonable pollution control measures decided by the authorities following an accident to the operator of the hazardous installation from which pollution is released. Such measures taken without undue delay by the operator or, in case of need, by the authorities would aim at promptly avoiding the spreading of environmental damage and would concern limiting the release of hazardous substances (e.g., by ceasing emissions at the plant, by erecting floating barriers on a river), the pollution as such (e.g., by cleaning or decontamination), or its ecological effects (e.g., by rehabilitating the polluted environment)."

${ }^{32}$ CAPPELLI, Silvia. Op. Cit., p. 323.
} 
Outra importante novidade foi a ideia de danos e de compensação incluídas como fundamentos do princípio do poluidor-pagador, desta vez, pela Recomendação do Conselho sobre o Uso de Instrumentos Econômicos na Política Ambiental:

1. Instrumentos econômicos têm o potencial de ser aplicado a diversas questões envolvendo recursos ambientais e naturais. A presente orientação lida com o uso dos instrumentos econômicos aqui definidos. Ademais, há outros tipos de instrumentos econômicos, como a aplicação de incentivos, multas, taxas por descumprimentos, encargos administrativos, acordos, compensação por danos, etc. que podem ter um papel nas políticas ambientais, mas não são consideradas aqui. ${ }^{33}$ (grifos meus)

Por fim, a Recomendação sobre a Utilização de Instrumentos Econômicos na Promoção e Conservação da Biodiversidade estabeleceu que a utilização de instrumentos econômicos para a proteção da biodiversidade pressupõe que os custos sociais de seu uso (benefícios), da degradação e da restauração possam ser internalizados no preço das atividades que causem a perda de biodiversidade (ganhos). Os problemas na administração da biodiversidade surgem de diferentes maneiras em diferentes ecossistemas e comunidades. Medidas de incentivos devem então ser designadas com as necessidades específicas de cada ecossistema e comunidade em mente. Independente da utilização de incentivos ou outras medidas, estes devem ser baseados na consideração de qual terá mais chance de ser eficiente e eficaz. ${ }^{34}$ Silvia Cappeli ${ }^{35}$ exemplifica como estes instrumentos econômicos podem ser utilizados:

\footnotetext{
${ }^{33}$ Tradução livre: "1. Economic instruments have the potential to be applied to a wide range of environmental and natural resources issues. The present guidelines deal with the use of economic instruments defined hereunder. In addition, there are other types of economic instruments such as enforcement incentives, fines, non-compliance fees, administrative charges, performance bonds, damage compensation, etc. which may have a role in environmental policy but are not considered here. Furthermore, the guidelines focus primarily on pollution issues although economic instruments also have considerable potential for application in the form of resource pricing."

${ }^{34}$ Tradução livre: "The use of economic instruments for biodiversity protection is predicated on the assumption that the social costs (benefits) of biodiversity use, degradation, and restoration can be internalised in the price of activities that cause these losses (gains) in biodiversity. Biodiversity management problems arise in different ways in different ecosystems and communities. Incentive measures therefore need to be designed with the specific needs of individual ecosystems and communities in mind. Whether incentive or other measures are used should be based on a consideration of which ones are likely to be most efficient and effective."
} 
Como exemplos de medidas de mercado que podem ser adotadas para a promoção de conservação e utilização sustentável da biodiversidade, ressaltam-se as "taxas de responsabilidade, cuja receita serve à proteção e à reabilitação de zonas ecologicamente sensíveis e a indenização em caso de danos à biodiversidade (inclusive os danos provisórios ou intermediários)" que, mais uma vez, denotam o caráter não apenas preventivo, mas também reparatório do princípio do poluidor-pagador.

Além das orientações da OCDE, o referido princípio também foi previsto em outros instrumentos internacionais, como, por exemplo, o Tratado da União Europeia, que o mencionou no parágrafo $2^{\circ}$ de seu art. 191 (ex artigo 174) ${ }^{36}$, prevendo-o como um dos princípios de sua política e impondo-o às instituições e aos Estados-Membros.

Neste contexto, a Declaração do Rio de Janeiro, de 1992, também o considerou merecedor de atenção:

\begin{abstract}
Princípio 16
As autoridades nacionais devem procurar promover a internacionalização dos custos ambientais e o uso de instrumentos econômicos, tendo em vista a abordagem segundo a qual o poluidor deve, em princípio, arcar com o custo da poluição, com a devida atenção ao interesse público e sem provocar distorções no comércio e nos investimentos internacionais. (grifos meus).
\end{abstract}

Sendo assim, mesmo tendo originado de uma regra de mercado, o princípio do poluidor-pagador é um importante mecanismo de redução de poluição,

Todavia, para que este objetivo seja realmente atingido, é necessário conferir largo alcance ao princípio, ampliando seu foco e elevando-o à condição de elemento conformador das atividades econômicas. Ainda que se leve em consideração a natureza econômica do princípio do poluidor-pagado, há que se

\footnotetext{
${ }^{35}$ CAPPELLI, Silvia. Op. Cit., p.323.

${ }^{36}$ Tratado da União Europeia, Artigo 191 (ex-artigo 174.o TCE):

2. A política da União no domínio do ambiente terá por objetivo atingir um nível de proteção elevado, tendo em conta a diversidade das situações existentes nas diferentes regiões da União. Basear-se-á nos princípios da precaução e da ação preventiva, da correção, prioritariamente na fonte, dos danos causados ao ambiente e do poluidor-pagador. Neste contexto, as medidas de harmonização destinadas a satisfazer exigências em matéria de proteção do ambiente incluirão, nos casos adequados, uma cláusula de salvaguarda autorizando os Estados-Membros a tomar, por razões ambientais não económicas, medidas provisórias sujeitas a um processo de controlo da União. Disponível em: http://eur-lex.europa.eu/LexUriServ/LexUriServ.do?uri=OJ:C:2012:326:FULL:PT:PDF.
} Acesso em 15.08.2013. 
chamar atenção para importantes preocupações nele inseridas, além daquelas relacionadas à eficiência do mercado e a evitar distorções no comércio internacional, quais sejam: (i) o foco na internalização dos custos de prevenção e controle da poluição e (ii) a promoção do uso racional dos recursos naturais. ${ }^{37}$

Por todo o exposto, vê-se que o princípio do poluidor-pagador é de suma importância para o Direito Ambiental, já que é este que orienta sua vocação redistributiva, ou seja, sua função de enfrentamento das deficiências do sistema de preços. ${ }^{38}$

Segundo Antonio Herman Benjamin, ${ }^{39}$ o referido princípio apoia-se na teoria da compensação, já que irá pagar quem provocar uma ação governamental, na medida do custo desta, e também na teoria do valor, pois quem se beneficia com a poluição, também deverá pagar na medida dos benefícios recebidos. Dessa forma,

O princípio quer significar que, dado o caráter difuso e esgotável dos bens ambientais (naturais e artificiais), todos que sejam responsáveis pela utilização desses bens em seu proveito (e em detrimento da sociedade) devem arcar com este déficit da coletividade. Esse déficit ambiental imposto à coletividade, quando possível de ser suportado e trouxer benefícios para a sociedade, deve ser internalizado por aquele que usa do meio ambiente em seu proveito (moral, econômico, social, etc.). Trata-se de evitar a socialização do prejuízo ambiental em proveito de um benefício privativo. ${ }^{40}$

A ideia é, portanto, redistribuir equitativamente as externalidades ambientais negativas, de forma que não se privatize o bônus e socialize o ônus, deixando para a coletividade suportar todos os impactos ambientais advindos daquele processo produtivo. Para que isto não ocorra, como viuse, é imprescindível que o poluidor internalize este custo em sua atividade, aplicando de forma correta e efetiva o princípio do poluidor-pagador. É neste contexto que entra a compensação ambiental, tratada no presente trabalho, como uma das formas de aplicação deste princípio.

Isto porque o art. 36 da Lei do SNUC densifica o princípio do poluidor-pagador, significando um mecanismo de assunção partilhada da responsabilidade social pelos custos ambientais derivados da atividade

\footnotetext{
${ }^{37}$ MOREIRA, Danielle de Andrade. Op. Cit., p. 37.

${ }^{38}$ BEJAMIN, Antonio Herman. Op. Cit., p. 2-3.

${ }^{39}$ Ibid. p. 6.

${ }^{40}$ RODRIGUES, Marcelo Abelha. Elementos de Direito Ambiental. Op. Cit. p. 195.
} 
econômica. $^{41}$

Trata-se, pois, da promoção de uma justiça distributiva, uma forma de compartilhar o ônus gerado pela atividade econômica com quem contribuiu e usufruiu do mesmo. Como bem lembra Paulo Affonso de Leme Machado: ${ }^{42}$

O princípio usuário-pagador não é uma punição, pois mesmo não existindo qualquer ilicitude no comportamento do pagador ele pode ser implementado. Assim, para tornar obrigatório o pagamento pelo uso do recurso ou pela sua poluição não há necessidade de ser provado que o usuário e o poluidor estão cometendo faltas ou infrações.

Desta forma, não é necessário que exista efetivamente um dano ambiental para que ocorra o chamado "compartilhamento de despesas", visto que o princípio do poluidor-pagador impõe o dever de responder pelas medidas de prevenção dos impactos ambientais que tenham a possibilidade de ocorrer futuramente com a implementação da atividade poluidora. Assim, ao dar início a uma atividade potencialmente causadora de significativo dano ambiental, o empreendedor deverá arcar com os custos da compensação ambiental, promovendo, desta forma, o compartilhamento dos custos das medidas preventivas daquela atividade.

\subsection{Licenciamento Ambiental}

O licenciamento ambiental é tema fundamental na análise da compensação ambiental porque é justamente no âmbito deste processo que a referida obrigação se efetiva.

Tal instrumento encontra-se previsto no art. $9^{\circ}$, IV da PNMA. Tratase de procedimento administrativo por meio do qual o órgão ambiental competente autoriza a instalação, localização, ampliação e operação de empreendimentos utilizadores de recursos ambientais, considerados

\footnotetext{
${ }^{41}$ Este foi o entendimento adotado pelo STF no julgamento da ADI 3378-6 (STF, ADI 3.3786/DF, Rel. Ministro Carlos Britto, Brasília, 09 abril, 2008), abordada ao longo do trabalho.

${ }^{42}$ MACHADO, Paulo Affonso Leme. Direito Ambiental Brasileiro. $21^{\mathrm{a}}$ ed. São Paulo: Editora Malheiros, 2013. p. 95.
} 
potencialmente poluidores ou possivelmente causadores de degradação ambiental. ${ }^{43}$ Sua natureza é essencialmente preventiva. ${ }^{44}$

Considerando que os danos ambientais são, via de regra, irreversíveis, ou de difícil reversibilidade, e de grande impacto, não apenas na sociedade atual, mas também nas gerações futuras, a importância do licenciamento ambiental deriva da constatação de que é mais válido prevenir a degradação ao meio ambiente do que tentar reverter o dano já causado. A preocupação com a prevenção funda-se, também, no reconhecimento constitucional do direito de todos a um meio ambiente ecologicamente equilibrado como visto anteriormente. ${ }^{45}$

Segundo o art. 36 da Lei do SNUC, que instituiu a compensação ambiental, o empreendedor deverá apoiar a implantação e manutenção de uma unidade de conservação do Grupo de Proteção Integral nos casos de licenciamento ambiental de empreendimentos causadores de significativo impacto ambiental, com fundamento no Estudo Prévio de Impacto Ambiental e no Relatório de Impacto Ambiental (EIA/RIMA), se forem assim considerados pelo órgão ambiental competente.

Dessa forma, a compensação ambiental apenas será exigida nos procedimentos de licenciamento ambiental quando, devido à magnitude do seu potencial degradador, estiver sujeito ao EIA/RIMA. Sendo assim, lembra Erika Bechara ${ }^{46}$ que:

(...) É da maior relevância a verificação dos empreendimentos sujeitos ao licenciamento ambiental e, mais do que isso, sujeitos à realização do EPIA/RIMA, porque potencialmente causadores de impacto ambiental significativo. Encontrando-se tais empreendimentos, encontrar-se-ão também pelo menos à luz da legislação atual - os "devedores" da compensação ambiental.

Ou seja, se determinada atividade causar um impacto ambiental negativo, mas não significativo, não estará sujeita ao pagamento da

\footnotetext{
${ }^{43}$ Resolução CONAMA 237/97, art. $1^{\circ}$, I.

${ }^{44}$ Para José Afonso da Silva, "as licenças ambientais, em geral, são atos administrativos de controle preventivo de atividades de particulares no exercício de seus direitos". (SILVA, José Afonso da. Direito Ambiental Constitucional. $8^{a}$ ed. São Paulo: Malheiros, 2010. p. 284).

${ }^{45}$ Art. 225 da CRFB/1988.

${ }^{46}$ BECHARA, Erika. Op. Cit. p. 213.
} 
compensação ambiental. Da mesma forma, outros estudos ambientais, como, por exemplo, Relatório Ambiental Preliminar (RAP), Análise Preliminar de Risco, Projeto de Controle Ambiental, não geram a obrigação da compensação ambiental. ${ }^{47}$

Apesar do art. 36 da Lei do SNUC ser bem claro neste aspecto e não permitir interpretação extensiva, há na doutrina quem defenda uma revisão do referido dispositivo de forma a englobar todos os empreendimentos sujeitos ao licenciamento ambiental, causadores de impactos ambientais negativos e inafastáveis, acreditando não ter sido a intenção do legislador retirar a obrigatoriedade do pagamento deste valor para atividades que não necessitam elaborar EIA/RIMA. Assim, alguns autores defendem que para atividades que causem um pequeno impacto ambiental, sendo impossível qualquer medida mitigatória, de recuperação ou recomposição, deverá haver algum tipo de compensação. ${ }^{48}$ Neste sentido, Erika Bechara ${ }^{49}$ sugere o seguinte:

(...) $\mathrm{O}$ art. 36 da Lei do SNUC deveria ser revisto para englobar em suas disposições todos os empreendimentos sujeitos ao licenciamento ambiental, causadores de impactos ambientais negativos e inafastáveis, ainda que desdobrando a compensação ambiental em dois tipos: uma aplicável aos empreendimentos causadores de impactos significativos, sujeitos ao EPIA/RIMA (é a compensação que já existe), outra aplicável aos demais empreendimentos sujeitos a outros estudos ambientais. No primeiro caso, os recursos da compensação seriam destinados às Unidades de Conservação; no segundo caso, a outros benefícios ambientais igualmente importantes, a serem definidos casuisticamente (com base em critérios técnicos, por óbvio) pelo órgão ambiental.

Diz-se danos inafastáveis, pois não é qualquer dano que gera a necessidade de pagamento da compensação ambiental. Neste sentido, os danos podem ser classificados em três ordens: (i) juridicamente

\footnotetext{
${ }^{47}$ ALMEIRDA, Marília Passos Torres de. Compensação ambiental na Lei do Sistema Nacional das Unidades de Conservação - Lei 9.985/00. Apud. BECHARA, Erika. Licenciamento e Compensação Ambiental na Lei do Sistema Nacional das Unidades de Conservação (SNUC). São Paulo: Editora Atlas, 2009. p. 214.

${ }^{48}$ É o que asseguram Fernanda Viana de Carvalho, Paula Rin de Souza e Lia D. Chagas Dornelles. (BECHARA, Erika. Op. Cit., p. 215-216).

${ }^{49}$ Ibid. p. 217.
} 
irrelevantes; (ii) juridicamente relevantes porém toleráveis; e (iii) juridicamente relevantes e intoleráveis. ${ }^{50}$

Considera-se que a primeira modalidade de danos, na realidade, nada mais é do que uma "alteração ambiental juridicamente irrelevante". Isto pois, apesar de causarem uma repercussão negativa no meio ambiente, não são consideradas ações efetivamente danosas, já que são de menor intensidade, podendo ser facilmente absorvidas pelo ambiente, sendo atividades normais e inerentes à vida em sociedade. Não sendo danosas, portanto, não são indenizáveis.

Assim, o próprio ordenamento jurídico impõe à coletividade o dever de suportar tais danos, posto que trata-se de atividades socialmente necessárias e toleradas ecologicamente como, por exemplo, a intensificação de poeira em uma via pública sob reparação, mesmo que isto provoque deterioração mais rápida da pintura dos muros das casas da região ou breve interrupção de uma rua para conserto de canalizações que poderá impedir o acesso dos veículos às casas de seus proprietários. ${ }^{51}$ Nestes casos, as vítimas terão que sofrer o prejuízo e arcar com as consequências sem serem indenizadas ou compensadas. ${ }^{52}$ Segundo Erika Bechara: ${ }^{53}$

Ora, se a compensação ambiental é um mecanismo de reparação de danos futuros, as alterações ambientais juridicamente irrelevantes - que não são consideradas como dano, do ponto de vista jurídico - não serão objeto da compensação ambiental.

Com relação aos danos juridicamente relevantes, porém toleráveis, estes sim são considerados como danos propriamente ditos e, portanto, ensejadores de responsabilização civil, reparação e indenização. É o exemplo da desapropriação, no qual o Estado está autorizado pelo Direito a

\footnotetext{
${ }^{50}$ Ibid. p. 230.

${ }^{51}$ BANDEIRA DE MELLO, Celso Antonio. Curso de Direito Administrativo. 18 ed. Rev. amp. Atual. São Paulo: Malheiros, 2007. V.1. Apud. BECHARA, Erika. Op. Cit., p. 231.

${ }^{52}$ BECHARA, Erika. Op. Cit., p. 230.

${ }^{53}$ Ibid. p. 231.
} 
desapropriar imóveis, mas o proprietário, por sofrer um prejuízo (dano jurídico), deverá receber indenização prévia, justa e em dinheiro. ${ }^{54}$

Caso os danos causados por empreendimentos potencialmente poluidores forem considerados toleráveis, aquela obra ou atividade poderá se desenvolver, mediante reparação ambiental prévia (também denominada compensação ambiental ex ante). Contudo, frise-se, se os danos forem considerados intoleráveis, a obra ou atividade não poderá ocorrer, nem mesmo com o pagamento da referida compensação ambiental prévia. ${ }^{55}$ Pode ser considerado dano intolerável a verificação, por exemplo, durante a elaboração do EIA, de que o empreendimento pode causar a extinção de alguma espécie da fauna ou da flora. ${ }^{56}$

Por isso, o primeiro ponto a ser averiguado não é se os danos são compensáveis, mas, se são admissíveis. Isto será verificado na etapa de elaboração do EIA/RIMA no processo licenciatório. Se for entendido que os danos daquele empreendimento são de fato intoleráveis à sociedade, não haverá pagamento de compensação ambiental ou qualquer obrigação de reparação, pois aquela atividade não deverá ser permitida pelo Direito e a licença não deverá ser concedida. Por outro lado, chegando-se à conclusão de que a alteração ambiental decorrente daquela atividade é tolerável, a mesma será permitida e o poluidor deverá pagar a compensação ambiental prévia. Assim,

Ao incidir sobre condutas lícitas, a compensação ambiental busca contrabalancear os riscos de danos que as atividades autorizadas possam vir a causar. Assim, o risco de sua incidência futura passa a integrar o conceito de dano ambiental, permitindo a imputação do dever de reparar antes mesmo da ocorrência da degradação.

(...) Assim, cabe ao Poder Público, quando da autorização de condutas que ocasionem prejuízos ambientais, condicionar seu consentimento ao prévio oferecimento, por parte dos empreendedores, de medidas que mitiguem ou compensem as repercussões ambientais de sua atividade, garantindo, assim, que

\footnotetext{
${ }^{54}$ Ibid. p. 232.

${ }^{55}$ Ibid. p. 231.

${ }^{56}$ ALMEIDA, Marília Passos Torres de. Compensação ambiental na Lei do Sistema Nacional das Unidades de Conservação - Lei 9.985/00. In: BENJAMIN, Antonio Herman (Org.). Paisagem, natureza e direito. São Paulo: Instituto o Direito por um Planeta Verde, 2005. v.2, p. 307-328. Apud. BECHARA, Erika. Op. Cit., p. 232.
} 
os impactos negativos na qualidade ambiental sejam minimizados e seja garantida a dinâmica dos biomas. ${ }^{57}$

Verifica-se então que há diversas situações que, apesar de danosas ao ambiente, são toleradas pelo ordenamento jurídico. Veja-se, neste sentido, a explanação de Erika Bechara: ${ }^{58}$

\begin{abstract}
A lesão irrelevante para o Direito nada mais é do que aquele prejuízo que as pessoas suportam, em geral, em nome da convivência social, e que, por essa razão, não é repudiado pelo direito e não gera às "vítimas" qualquer tipo de reparação. Na verdade, sequer se trata de dano jurídico. Já a atividade danosa autorizada pelo Direito é aquela que está amparada ou senão determinada por uma norma jurídica, mas que, nada obstante, causa um dano jurídico e indenizável a terceiro, isto é, um dano que este terceiro teria o direito de não sofrer. E o dano tolerado pelo Direito significa a lesão jurídica e indenizável, resultado da atividade danosa autorizada pelo Direito, mas ela própria, lesão, não autorizada pelo Direito, sendo quando muito suportada porque impossível contêla - por isso a vítima desta lesão sempre faz jus a uma reparação/indenização.

(...) Transportando a lição para o Direito Ambiental, mais precisamente para o licenciamento de atividades potencialmente poluidoras, temos que algumas dessas atividades causarão danos ambientais no futuro - devidamente previstos no licenciamento - mas que, sendo eles juridicamente toleráveis, não obstarão o empreendimento.

Os danos ambientais, conquanto autorizados, não deixam de ser danos e, $a$ fortiori, não deixam de ser reparáveis ou indenizáveis. Daí se falar em compensação ambiental ex ante, que nada mais é do que uma reparação antecipada pelos danos ambientais que advirão da atividade licenciada.
\end{abstract}

Se faz importante neste momento diferenciar a denominada responsabilidade civil ex ante da chamada responsabilidade civil ex post. Ambas têm como finalidade precípua contribuir para a manutenção da integridade da qualidade ambiental vista de forma ampla, sendo duas formas distintas de manifestação da responsabilidade civil ambiental, formando um sistema complementar em que a imputação do dever de reparar pode ocorrer antes ou depois da efetivação do dano.

Por um lado tem-se a responsabilidade civil ex post, que se manifesta como consequência direta e objetiva de um dano ambiental, surgindo do regime tradicional de responsabilidade civil objetiva (art. 14 da Lei

\footnotetext{
${ }^{57}$ FERREIRA, Gabriel; SILVA, Solange. Op. Cit., p. 131.

${ }^{58}$ BECHARA, Erika. Op. Cit. p. 232-233.
} 
6.938/1981, art. 927, parágrafo único do Código Civil e art. $3^{\circ}$ da Lei $7.347 / 1985) .{ }^{59}$ Neste caso,

(...) Há a obrigação de reparar após ocorrido o dano. A compensação é então definida de modo posterior à deflagração do dano (compensação ex post), revestindo-se de uma índole repressiva que assume a feição de um instrumento educativo-sancionador. A compensação estabelecida ex post refere-se, portanto, a uma medida regulada judicialmente, sendo estabelecida por meio de decisão do Poder Judiciário que determina a pertinência e os contornos dessa forma de reparação do dano ambiental. ${ }^{60}$

Por outro lado, a responsabilidade civil ex ante trata-se de instrumento preventivo, já que impõe previamente ao início do funcionamento de uma atividade potencialmente danosa ao meio ambiente, a obrigação de pagar compensação ambiental, resultante de previsões obtidas em estudos de avaliação do impacto ambiental. ${ }^{61}$ Em síntese,

Diante da sistemática de funcionamento da responsabilidade ex ante, a definição e estipulação das medidas compensatórias também são realizadas de maneira anterior à deflagração das alterações no meio ambiente. Resultante de uma atividade licitamente exercida, a compensação ex ante, ao contrário da ex post, reúne contornos de uma medida de contraprestação, desprovida de caráter sancionador, cuja função distributiva objetiva precipuamente a manutenção da qualidade ambiental. Com efeito, a compensação estabelecida ex ante se qualifica como uma medida regulada na seara administrativa, sendo definida e estabelecida por meio de decisão do órgão competente que, diante de prejuízos ambientais não mitigáveis, produzidos por empreendimentos ou obras autorizados, determina a pertinência e os contornos da compensação ambiental devida. ${ }^{62}$

\section{Entretanto, como bem ressalta Solange Teles da Silva e Gabriel Luis}

Bonora Vidrih Ferreira embasados por Gustavo Ordoqui Castilla, ${ }^{63}$

A sistemática fundada na responsabilidade ex post não tem possibilitado uma prevenção eficiente dos danos e riscos de danos ambientais. Na realidade, o ordenamento jurídico brasileiro não admite a existência de um direito à degradação da qualidade ambiental, já que o próprio texto constitucional assegura

\footnotetext{
${ }^{59}$ FERREIRA, Gabriel; SILVA, Solange. Op. Cit., p. 129.

${ }^{60}$ Ibid.

${ }^{61}$ CONDE ANTEQUERA, Jesús. El deber jurídico de restauración ambiental. Granada: Comares, 2004. p. 266. Apud. FERREIRA, Gabriel; SILVA, Solange. Op. Cit., p. 129.

${ }^{62}$ FERREIRA, Gabriel; SILVA, Solange. Op. Cit., p. 135.

${ }^{63}$ CASTILLA, Gustavo Ordoqui. Obligación de compensar danos causados por docutas licitas. Revista dos Tribunais. São Paulo, v. 726, p. 11-23, abr. 1996. P. 13-14. Apud. FERREIRA, Gabriel; SILVA, Solange. Op. Cit., p. 133.
} 
a todos o direito fundamental ao meio ambiente ecologicamente equilibrado. A responsabilidade ex ante surge, então, para complementar o instituto da responsabilidade civil ambiental ex post a partir de uma lógica conservacionista. O exercício de uma atividade lícita pode provocar efeitos ambientais negativos na esfera do direito de todos a um meio ambiente ecologicamente equilibrado e, assim, a adoção da responsabilidade civil ex ante, cuja função não é sancionatória, mas sim eminentemente preventiva, compensatória e distributiva, objetiva resolver conflitos de interesse conforme a máxima da justiça distributiva.

Sendo assim, a compensação ambiental ex ante vem justamente para tornar o sistema da responsabilidade civil ambiental completo, não apenas reparando danos após sua concretização, mas prevenindo aqueles que possam ser previstos no licenciamento ambiental e que sejam toleráveis social e ecologicamente, de forma a conservar o meio ambiente da melhor forma possível.

Acerca da mencionada compensação ambiental ex ante necessário ainda diferenciá-la das chamadas medidas compensatórias. Enquanto a primeira é de caráter genérico e focado no impacto negativo geral do empreendimento a segunda são as medidas compensatórias impostas pelo órgão ambiental como condicionantes do licenciamento. Apesar de a nomenclatura parecer similar é importante não confundi-las.

De fato, há que se considerar que ambas partem do mesmo princípio, qual seja: de que determinadas atividades causam impactos ambientais inevitáveis, mas que, independentemente, terão que ser realizadas com base no interesse público. Já que a coletividade terá que suportar estes impactos, merece ser recompensada e, por isso, ambas têm a finalidade de compensar um dano ambiental inafastável. ${ }^{64}$

Tendo isto em mente, é de suma importância diferenciá-las afim de evitar a ocorrência de bis in idem. Segundo Édis Milaré e Priscila Santos Artigas, ${ }^{65}$

(...) Há que se mencionar que normalmente os órgãos ambientais licenciadores impõem, antes mesmo de qualquer investida no meio ambiente, condicionantes

\footnotetext{
${ }^{64}$ BECHARA, Erika. Op. Cit., p. 238.

${ }^{65}$ MILARÉ, Édis; ARTIGAS, Priscila Santos. Compensação Ambiental: questões controvertidas: Revista de Direito Ambiental. São Paulo, n. 43, p. 101-114, julho. 2006. p. 4.
} 
de natureza compensatória nas licenças ambientais emitidas. São as chamadas medidas compensatórias, que podem ser assim exemplificadas: o fomento de um programa de educação ambiental; o financiamento de pesquisas científicas; o replantio da mata ciliar de um rio importante para o município e outras muitas.

Assim, a compensação ambiental prévia será sempre exigida nos casos de atividades que possam causar significativo impacto ambiental, estando sujeitas à elaboração de EIA/RIMA. Neste caso, o responsável por este empreendimento deverá pagar o referido valor, que será destinado à aplicação de recursos, necessariamente, em unidades de conservação. Já as medidas compensatórias, por serem mais específicas, são voltadas para impactos pontuais da obra ou da atividade e deverão ser exigidas nos casos de empreendimentos que causem impactos ambientais negativos, porém não significativos, dispensados, portanto, da elaboração de EIA/RIMA. ${ }^{66}$

Surge, então a seguinte questão: sendo ambas voltadas para contrabalancear um prejuízo ambiental ocorrido no processo de licenciamento ambiental, apesar de terem formas de atuação distintas, poderiam vir a incidir ao mesmo tempo? Em outras palavras, poderia o órgão ambiental exigir do empreendedor as duas formas de compensação sobre um mesmo dano?

Segundo os referidos autores, a resposta é não. Não há a possibilidade de cumulação da compensação ambiental prévia e de medidas compensatórias específicas em um mesmo licenciamento ambiental, sob pena de ocorrer o chamado bis in idem. Sobre este aspecto, merece novamente destaque a explicação de Édis Milaré e Priscila Santos Artigas: ${ }^{67}$

De fato, o dano ou impacto é um só, de modo que a forma de compensação desse dano ou impacto também deve ser uma só. Assim, nas ocasiões em que a hipótese de incidência da compensação ambiental prevista no art. $36, \S 1 .^{\circ}$, da Lei 9.985/2000 se concretizar (qual seja: licenciamento de empreendimento de significativo impacto ambiental, de acordo com o EIA/RIMA), há que se exigir tão somente o seu pagamento, mediante a destinação de valor específico para a implantação de unidade de conservação. Nessas circunstâncias, portanto, não podem ser impostas medidas compensatórias no decorrer do licenciamento ambiental.

\footnotetext{
${ }^{66}$ BECHARA, Erika. Op. Cit., p. 238.

${ }^{67}$ MILARÉ, Édis; ARTIGAS, Priscila Santos. Op. Cit., p. 4.
} 
(...) Nosso entender, todavia, é que a sobreposição da compensação ambiental nas medidas compensatórias, exigidas ou não por lei, fere o princípio de que ninguém deverá arcar duas vezes pelo mesmo impacto/prejuízo ambiental. Dito às secas e às claras, ou se impõe o pagamento da exação prescrita no art. $36, \S 11^{\circ}$, da Lei 9.985/2000, vulgarmente denominada compensação ambiental, ou se exige a implementação de medidas compensatórias no decorrer do processo de licenciamento ambiental.

Contudo, há exceções para a referida regra. Erika Bechara ${ }^{68}$ excepciona certas situações em que poderá haver a cumulação de ambas:

É como se a lei dissesse que, para certos casos, mais vale uma compensação específica do que uma compensação geral - decerto porque a primeira oferece um sucedâneo mais próximo e relacionado ao próprio dano causado. Na hipótese, por exemplo, da compensação para supressão de Mata Atlântica, calcada no reflorestamento da mesma quantia de vegetação suprimida, a lei parece entender mais benéfico usar a compensação para evitar a diminuição de remanescentes florestais do bioma (em porções já tão ínfimas) do que para investir na melhoria de uma unidade de conservação.

Em nosso pensar, quando a lei estabelecer uma medida compensatória específica, ela deverá ser exigida pelo órgão licenciador inclusive nos licenciamentos ambientais sujeitos à compensação ambiental ex ante. Em casos tais, compensação ambiental e medida compensatória terão que conviver no mesmo processo, mas o impacto que for objeto da medida compensatória não deverá ser computado na compensação ambiental, sob pena de bis in idem. ${ }^{69}$

Sendo assim, pode-se afirmar que, via de regra, não será possível cumular ambas as formas de compensação, tendo em vista a vedação pelo ordenamento jurídico de obrigar o poluidor a pagar duas vezes pelo mesmo dano. Entretanto, nas situações em que a própria lei determinar forma de compensação específica para aquele tipo de dano individualmente, a regra geral será afastada, dando espaço para que o órgão licenciador exija do empreendedor o cumprimento de ambas simultaneamente. Lembrando que, para evitar a ocorrência de bis in idem, o impacto que for objeto da medida compensatória específica não poderá ser computado na compensação ambiental do art. 36 da Lei do SNUC.

Por todo o exposto, verifica-se que a compensação ambiental prévia ou compensação ambiental ex ante representa a conjugação da obrigação do

\footnotetext{
${ }^{68}$ BECHARA, Erika. Op. Cit., p. 240.

${ }^{69} \mathrm{Ibid}$
} 
empreendedor de abster-se de prejudicar o meio ambiente com a obrigação do Poder Público de proteger sua integridade. O modelo tradicional de responsabilidade civil passou a ter novos contornos a partir de seu entrosamento com os princípios do Direito Ambiental, tais como o princípio do poluidor-pagador. Em última análise, o que se busca é a conservação da qualidade ambiental para as presentes e futuras gerações. ${ }^{70}$

Restam, portanto, expostos os fundamentos e os princípios centrais da compensação ambiental. Para melhor compreende-la, se faz necessário agora analisar o histórico da cobrança do referido instituto.

\section{Histórico da Cobrança}

\subsection{Regulamentação anterior à Lei do SNUC}

Antes da edição da Lei 9.985/2000 (Lei do SNUC) que instituiu a Compensação Ambiental tratada no presente trabalho, alguns atos normativos foram relevantes para traçar seu histórico. O primeiro deles é a Resolução CONAMA 10/1987, que exigiu, em seu art. $1^{\circ}$, que

\footnotetext{
Para fazer face à reparação dos danos ambientais causados pela destruição de florestas e outros ecossistemas, o licenciamento de obras de grande porte, assim considerado pelo órgão licenciador com fundamento no RIMA terá sempre como um dos seus pré-requisitos, a implantação de uma Estação Ecológica pela entidade ou empresa responsável pelo empreendimento, preferencialmente junto à área. (grifos meus).
}

Ademais, a referida resolução determinou que o montante dos recursos a serem utilizados na área, assim como o valor dos serviços e das benfeitorias, deveria ser proporcional ao dano ambiental, não podendo ser inferior a $0,5 \%$ dos custos totais previstos para a implantação do empreendimento. ${ }^{71} \mathrm{O}$ momento para determinar a extensão, os limites e outras características da Estação Ecológica a ser implantada, seria durante o licenciamento ambiental do empreendimento e a manutenção da mesma deveria ser realizada pela entidade ou empresa responsável de forma direta

\footnotetext{
${ }^{70}$ FERREIRA, Gabriel; SILVA, Solange. Op. Cit., p. 135.

${ }^{71}$ Art. $2^{\circ}$ da Resolução CONAMA 10/1987.
} 
ou através de convênio celebrado com o Poder Público. ${ }^{72}$ O Relatório de Impacto Ambiental (RIMA) deveria apresentar proposta ou projeto, indicando alternativas para o atendimento no disposto na mencionada Resolução. ${ }^{73}$ Desta forma, tal obrigação ocorria durante a fase de avaliação de impactos, ou seja, antes da ocorrência de um dano concreto e não após a implantação do empreendimento. ${ }^{74}$

Esta obrigação, que consistia em uma obrigação de fazer, foi instituída pela referida Resolução com fundamento no art. $4^{\circ}$, I, da Lei 6.938/1981: “A Política Nacional do Meio Ambiente visará à compatibilização do desenvolvimento econômico-social com a preservação da qualidade do meio ambiente e do equilíbrio ecológico". 75

Em 18 de abril de 1996, foi editada a Resolução CONAMA 02 que revogou expressamente a previsão legal anterior. Seu art. $1^{\circ}$ previu diversamente da norma revogada, que o licenciamento de empreendimentos de relevante impacto ambiental, considerados pelo órgão ambiental com fundamento no EIA/RIMA, teria como um dos requisitos a serem atendidos pela entidade licenciada, a implantação de uma unidade de conservação de domínio público e uso indireto, preferencialmente uma Estação Ecológica, a critério do órgão licenciador, ouvido o empreendedor.

Em síntese, a Resolução CONAMA 10/1987,

(...) foi modificada pela Resolução CONAMA 002/96, que trouxe importantes alterações em relação à anterior, pois seu art. $1^{\circ}$ dizia que: (i) não havia necessidade de ser uma estação ecológica, e, mais ainda, que deveria (ii) ser de domínio público e (iii) preferencialmente de uso indireto. ${ }^{76}$

\footnotetext{
${ }^{72}$ Art. $3^{\circ}$ e $5^{\circ}$ da Resolução CONAMA $10 / 1987$

${ }^{73}$ Art. $4^{\circ}$ da Resolução CONAMA 10/1987.

${ }^{74}$ MACIEL, Marcela Albuquerque. Compensação Ambiental: Instrumento para a implementação do Sistema Nacional de Unidades de Conservação. São Paulo: Letras Jurídicas, 2012. p. 135.

75 Acórdão $\mathrm{n}^{\circ}$ 1853/2013-TCU-Plenário, p. 75. Disponível em: http://portal2.tcu.gov.br/portal/page/portal/TCU/imprensa/noticias/noticias arquivos/014.2932012-9\%20(Compensacao\%20Ambiental).pdf. Acesso em 25.10.2013.

76 RODRIGUES, Marcelo Abelha. Aspectos Jurídicos da Compensação Ambiental. p. 3. Disponível em: http://www.marceloabelha.com.br/site/publicacoes.php. Acesso em 21.08.2013.
} 
A nova resolução determinou ainda que o valor pago a título de compensação poderia ser destinado às unidades de conservação já existentes ou a serem criadas ou à implantação de uma única unidade para atender a mais de um empreendimento na mesma área de influência. As áreas beneficiadas deveriam ser localizadas, de preferência, mas não obrigatoriamente, na região do empreendimento. ${ }^{77}$

Desde a edição desta resolução, foi previsto que parte dos recursos da compensação poderiam ser destinados a atividades não atribuídas diretamente ao empreendedor, sendo necessária sua transferência ao Poder Público, conforme disposto no parágrafo único do art. $3^{\circ}$ do referido ato normativo. $^{78}$

Novamente o mesmo percentual utilizado anteriormente foi mantido ao ser determinado que o montante dos recursos a ser empregado, bem como o valor dos serviços e das obras de infraestrutura deveria ser proporcional à alteração e ao dano ambiental a ser ressarcido, não podendo ser inferior $0,5 \%$ dos custos totais previstos para a implantação do empreendimento. $^{79}$

Após a criação da unidade, o responsável pelo empreendimento deveria transferir seu domínio ao Poder Público responsável pela administração de unidades de conservação, realizando sua manutenção mediante convênio com o órgão competente. Este, deveria também fiscalizar a implantação das mesmas ou da alternativa adotada. ${ }^{80}$

Vê-se, desta forma, que a compensação ambiental, desde suas origens e até o dia de hoje, está relacionada ao licenciamento ambiental de empreendimentos potencialmente causadores de significativa degradação ambiental, sendo voltado para compensar os impactos tidos como irreversíveis e/ou inevitáveis.

Contudo, como esclarece Erika Bechara, ${ }^{81}$

\footnotetext{
${ }^{77}$ Art. $1^{\text {o }}, \S \S 1^{\text {o e }} 2^{\text {o }}$ da Resolução CONAMA 02/1996.

${ }^{78}$ MACIEL, Marcela Albuquerque. Op. Cit., p. 136.

${ }^{79}$ Art. $2^{\circ}$ da Resolução CONAMA 02/1996.

${ }^{80}$ Arts. $5^{\circ}$ e $6^{\circ}$ da Resolução CONAMA 02/1996.

${ }^{81}$ BECHARA, Erika. Op. Cit., p. 163-164.
} 
De início, a compensação ambiental tinha um alcance menor do que o atual, sendo exigida apenas dos empreendimentos que pudessem destruir florestas e outros ecossistemas (e não o meio ambiente como um todo, deixando de lado, p. ex., meio ambiente cultual e do trabalho), em favor da implantação de uma estação ecológica (e não das unidades de conservação do grupo de proteção integral).

(...)

A Resolução sucessora ampliou o objeto da compensação ambiental, permitindo que os recursos desembolsados pelo empreendedor a esse título fossem aplicados em outras unidades de conservação públicas de proteção integral (rectius: uso indireto) que não, exclusivamente, as estações ecológicas.

Apesar de hoje a mesma ser exigida pela Lei do SNUC, originalmente a compensação tinha como base legal as resoluções aqui tratadas, mesmo não tendo recebido até então o termo "compensação ambiental". Este apenas foi inserido mais adiante.

$\mathrm{Na}$ época em que vigoravam as referidas resoluções, o principal debate era acerca da constitucionalidade de tais atos normativos, o que acabou por dificultar sua aplicação pelos órgãos licenciadores. $\mathrm{O}$ argumento principal para fundamentar sua inconstitucionalidade era de que o art. 25 do Ato das Disposições Constitucionais Transitórias (ADCT) estabeleceu a revogação, a partir de 180 dias da promulgação da CRFB/1988, dos dispositivos legais que atribuíam ou delegavam a órgão do Poder Executivo, competência constitucional do Congresso Nacional. Assim, grande parte dos empreendedores à época resistiu à compensação ambiental, sob o argumento de que obrigações deste tipo só poderiam ser instituídas por lei, pelo princípio da legalidade, e não por ato infralegal como uma Resolução do CONAMA. ${ }^{82}$

A conclusão, no entanto, foi pela constitucionalidade das resoluções, já que ambas amparavam-se diretamente na Lei $6.938 / 1981,{ }^{83}$ sendo tal matéria de competência do CONAMA e não do Congresso Nacional, já que o art. 225 da CRFB/1988 tratou apenas da obrigatoriedade legal do EIA

\footnotetext{
${ }^{82}$ Ibid. p. 164.

${ }^{83}$ Art. $8^{\circ}$, I da Lei 6.938/81.
} 
para a instalação de obra ou atividade potencialmente causadora de significativa degradação do meio ambiente. ${ }^{84}$

De qualquer forma, como bem lembra Erika Bechara ${ }^{85}$

\begin{abstract}
A relutância em aceitar a compensação ambiental pelo argumento do desrespeito ao princípio da legalidade não mais se sustenta desde a aprovação da Lei 9.985/2000 (institui o Sistema Nacional das Unidades de Conservação - SNUC), haja vista ter este diploma legal - lei em sentido formal - regulado o instituto da compensação.
\end{abstract}

\title{
2.2. Regulamentação posterior à Lei do SNUC
}

Finalmente, em 18 de julho de 2000, a Lei 9.985 instituiu o Sistema Nacional de Unidades de Conservação (SNUC), revogando tacitamente a mencionada Resolução 002/1996 ${ }^{86}$ e dispondo, em seu Capítulo IV, ao tratar sobre criação, implantação e gestão das unidades de conservação, o seguinte:

Art. 36. Nos casos de licenciamento ambiental de empreendimentos de significativo impacto ambiental, assim considerado pelo órgão ambiental competente, com fundamento em estudo de impacto ambiental e respectivo relatório - EIA/RIMA, o empreendedor é obrigado a apoiar a implantação e manutenção de unidade de conservação do Grupo de Proteção Integral, de acordo com o disposto neste artigo e no regulamento desta Lei.

$\S 1^{\circ} \mathrm{O}$ montante de recursos a ser destinado pelo empreendedor para esta finalidade não pode ser inferior a meio por cento dos custos totais previstos para a implantação do empreendimento, sendo o percentual fixado pelo órgão ambiental licenciador, de acordo com o grau de impacto ambiental causado pelo empreendimento. ${ }^{87}$

$\S 2^{\underline{o}}$ Ao órgão ambiental licenciador compete definir as unidades de conservação a serem beneficiadas, considerando as propostas apresentadas no EIA/RIMA e ouvido o empreendedor, podendo inclusive ser contemplada a criação de novas unidades de conservação.

$\S 3^{\circ}$ Quando o empreendimento afetar unidade de conservação específica ou sua zona de amortecimento, o licenciamento a que se refere o caput deste artigo só poderá ser concedido mediante autorização do órgão responsável por sua administração, e a unidade afetada, mesmo que não pertencente ao Grupo de

\footnotetext{
${ }^{84}$ MACIEL, Marcela Albuquerque. Op. Cit., p. 137-138.

${ }^{85}$ BECHARA, Erika. Op. Cit., 164.

${ }^{86}$ MILARÉ, Édis. Op. Cit., p. 1238.

${ }^{87}$ Em razão do julgamento da ADI 3.378-6/2008 (STF, ADI 3.378-6/DF, Rel. Ministro Carlos Britto, Brasília, 09 abril, 2008), conforme será tratado adiante.
} 
Proteção Integral, deverá ser uma das beneficiárias da compensação definida neste artigo. (grifos meus)

Verifica-se que o legislador manteve parte do que as Resoluções anteriores previram, merecendo destaque três aspectos principais da compensação ambiental mencionadas no caput do referido dispositivo: (i) estará presente em todo licenciamento ambiental de atividades que tenham o potencial de causar significativo impacto ambiental (nos termos do art. 225, § $1^{\circ}$, IV, da CFRB/1988), ou seja, que envolva a realização de EIA/RIMA; (ii) o empreendedor tem um dever legal; (iii) de apoiar a implantação e manutenção de uma unidade de conservação de proteção integral. ${ }^{88}$

Vê-se, portanto, que o caput do referido artigo estabeleceu a obrigatoriedade do pagamento da compensação ambiental como mencionado acima, enquanto as questões acerca de seu modus operandi foram deixadas para os parágrafos.

Neste sentido, o parágrafo $1^{\circ}$ estabeleceu um piso ao determinar que o montante de recursos a ser destinado para esta finalidade não poderia ser inferior a $0,5 \%$ dos custos totais do empreendimento.

O parágrafo $2^{\circ}$, por sua vez, estipulou que cabe ao órgão ambiental definir que unidade de conservação será beneficiada, considerando as propostas do EIA/RIMA e o contraditório do empreendedor, sendo possível a criação de novas unidades de conservação.

No caso do próprio empreendimento afetar uma unidade de conservação já existente ou sua zona de amortecimento, explica o parágrafo $3^{0}$ que haverá duas consequências: (i) o licenciamento dependerá de autorização do órgão responsável pela gestão da unidade de conservação e (ii) a unidade de conservação afetada será necessariamente beneficiária daquela compensação ambiental, mesmo se não pertencer ao Grupo de Proteção Integral. ${ }^{89}$

\footnotetext{
${ }^{88}$ RODRIGUES, Marcelo Abelha. Aspectos Jurídicos da Compensação Ambiental. Op. Cit. p. 4-5.

${ }^{89}$ Ibid. p. 5.
} 
Percebe-se, que o dispositivo em questão manteve parte do que as Resoluções CONAMA 10/1987 e 02/1996 tratavam. Contudo, apesar dos desdobramentos trazidos pelos parágrafos, algumas questões que já eram debatidas nesta época permaneceram omissas, fazendo com que certas dúvidas permanecessem. Algumas delas são: a falta de fixação de um percentual máximo, o cálculo sobre o custo total do empreendimento e a forma de execução da compensação ambiental, ou seja, de que forma seria o empreendedor obrigado a apoiar a criação e manutenção de uma unidade de conservação. ${ }^{90}$

Devemos nos atentar para o fato de que o art. 36 da Lei do SNUC utilizou o verbo "apoiar", não deixando claro qual seria a real obrigação do empreendedor. Haveria, portanto, uma obrigação para o empreendedor de realizar a atividade de forma direta? Ou seria possível promover um repasse financeiro?

Outra alteração relevante trazida pela nova lei foi o fato de não se mencionar a reparação por dano a florestas e outros ecossistemas, mas sim a compensação pelo impacto ambiental causado pelo empreendimento. Antes da Lei do SNUC apenas as atividades capazes de causar um dano diretamente às florestas e outros ecossistemas teriam seu licenciamento condicionado à obrigação de pagar a compensação ambiental.

Segundo Marcela Maciel, ${ }^{91}$ esta novidade corrigiu a impropriedade técnica de se tratar de reparação de danos quando, na realidade, a obrigação surge no momento da avaliação dos possíveis impactos que não serão necessariamente concretizados com o desenvolver da atividade. A referida autora defende que

(...) Atualmente, qualquer atividade capaz de causar significativo impacto ambiental deve ser condicionada à compensação ambiental do art. 36 do SNUC. Essa distinção reflete a compreensão mais atual de que toda forma de poluição e degradação pode acabar impactando negativamente a biodiversidade, especialmente quanto às atividades e empreendimentos sujeitos ao EIA, por

\footnotetext{
${ }^{90}$ MACIEL, Marcela Albuquerque. Op. Cit., p. 141.

${ }^{91}$ Ibid. p. 141-142.
} 
serem de significativo impacto ambiental, o que não se resume aos casos de supressão direta de vegetação.

Com o intuito de regulamentar este artigo, foi editado o Decreto 4.340/2002, alterado posteriormente pelo Decreto 5.566/2005, que dispõe sobre compensação ambiental, atualmente, o seguinte:

Art. 31. Para os fins de fixação da compensação ambiental de que trata o art. 36 da Lei $\mathrm{n}^{\circ}$ 9.985, de 2000, o órgão ambiental licenciador estabelecerá o grau de impacto a partir de estudo prévio de impacto ambiental e respectivo relatório - EIA/RIMA realizados quando do processo de licenciamento ambiental, sendo considerados os impactos negativos e não mitigáveis aos recursos ambientais. (Redação dada pelo Decreto $n^{\circ} 5.566$, de 2005).

Parágrafo único. Os percentuais serão fixados, gradualmente, a partir de meio por cento dos custos totais previstos para a implantação do empreendimento, considerando-se a amplitude dos impactos gerados, conforme estabelecido no caput.

Art. 32. Será instituída no âmbito dos órgãos licenciadores câmaras de compensação ambiental, compostas por representantes do órgão, com a finalidade de analisar e propor a aplicação da compensação ambiental, para a aprovação da autoridade competente, de acordo com os estudos ambientais realizados e percentuais definidos.

Art. 33. A aplicação dos recursos da compensação ambiental de que trata o art. 36 da Lei $n^{\circ}$ 9.985, de 2000, nas unidades de conservação, existentes ou a serem criadas, deve obedecer à seguinte ordem de prioridade:

I - regularização fundiária e demarcação das terras;

II - elaboração, revisão ou implantação de plano de manejo;

III - aquisição de bens e serviços necessários à implantação, gestão, monitoramento e proteção da unidade, compreendendo sua área de amortecimento;

IV - desenvolvimento de estudos necessários à criação de nova unidade de conservação; e

$\mathrm{V}$ - desenvolvimento de pesquisas necessárias para o manejo da unidade de conservação e área de amortecimento.

Parágrafo único. Nos casos de Reserva Particular do Patrimônio Natural, Monumento Natural, Refúgio de Vida Silvestre, Área de Relevante Interesse Ecológico e Área de Proteção Ambiental, quando a posse e o domínio não sejam do Poder Público, os recursos da compensação somente poderão ser aplicados para custear as seguintes atividades:

I - elaboração do Plano de Manejo ou nas atividades de proteção da unidade;

II - realização das pesquisas necessárias para o manejo da unidade, sendo vedada a aquisição de bens e equipamentos permanentes;

III - implantação de programas de educação ambiental; e

IV - financiamento de estudos de viabilidade econômica para uso sustentável dos recursos naturais da unidade afetada.

Art. 34. Os empreendimentos implantados antes da edição deste Decreto e em operação sem as respectivas licenças ambientais deverão requerer, no prazo de doze meses a partir da publicação deste Decreto, a regularização junto ao órgão 
ambiental competente mediante licença de operação corretiva ou retificadora. (grifos meus).

Cumpre ressaltar que, originalmente, o art. 31 do referido decreto dispunha da seguinte forma:

Art. 31. Para os fins de fixação da compensação ambiental de que trata o art. 36 da Lei no 9.985 , de 2000, o órgão ambiental licenciador estabelecerá o grau de impacto a partir dos estudos ambientais realizados quando do processo de licenciamento ambiental, sendo considerados os impactos negativos, não mitigáveis e passíveis de riscos que possam comprometer a qualidade de vida de uma região ou causar danos aos recursos naturais. (grifos meus).

Veja-se que o Decreto utilizou a expressão genérica "estudos ambientais", ao invés de se referir especificamente ao EIA como fez a Lei do SNUC. Tal problema foi identificado quando a Câmara Técnica de Assuntos Jurídicos (CATJ) analisou o texto da Resolução CONAMA 371/2006, que será abordada adiante, resultando na alteração do caput do citado dispositivo pelo Decreto 5.566/2006. ${ }^{92}$

Em sua redação original, o dispositivo considerou "os impactos negativos, não mitigáveis e passíveis de riscos que possam comprometer a qualidade de vida de uma região ou causar danos aos recursos naturais" como os impactos a serem considerados para a definição da compensação ambiental. No entanto, devemos nos atentar para o fato de que

Apesar da referência à expressão "danos aos recursos naturais", destaca-se que o Decreto deixa claro que o escopo da compensação ambiental são os impactos passíveis de causar esses danos, e não os danos em si. ${ }^{93}$

De qualquer forma, tal expressão foi retirada quando da alteração do referido dispositivo pelo Decreto 5.566/2006 acabando com qualquer dúvida que poderia surgir quanto ao conceito de impacto ambiental para fins de pagamento da compensação ambiental. Sendo assim, com a retirada do texto, a nova redação passou a ampliar a competência do órgão ambiental para fixar a compensação. ${ }^{94}$

\footnotetext{
${ }^{92}$ Ibid. p. 146-147.

${ }^{93}$ Ibid. p. 146.

${ }^{94}$ SOARES, Sinara. As Inovações da Base de Cálculo da Compensação Ambiental da Lei do Sistema Nacional das Unidades de Conservação Decreto 6.848/2009: Revista de Direito Ambiental. São Paulo: Revista dos Tribunais, n. 69: p. 299, 2013. p. 3.
} 
No que tange o método de cálculo para alcançar o valor da compensação ambiental, o parágrafo único do art. 31 fixou nova regra. $\mathrm{O}$ percentual deveria ser fixado de forma gradual, a partir de $0,5 \%$ dos custos da implantação do empreendimento, considerando o impacto gerado.

Além disso, o art. 33 trouxe outra novidade, qual seja: ordem de prioridade para a aplicação dos recursos provenientes da compensação ambiental, atentando-se para os casos nos quais as unidades de conservação não sejam de posse e domínio públicos, conforme parágrafo único do referido artigo.

Com o objetivo de analisar e propor a aplicação da compensação ambiental de acordo com os estudos realizados, o art. 32 determinou a criação no âmbito dos órgãos licenciadores das chamadas câmaras de compensação ambiental. Em âmbito federal, esta câmara passou por diferentes interpretações e composições ao longo do tempo, inclusive com a criação do ICMBio, que sucedeu o IBAMA na gestão dos recursos advindos da compensação ambiental. ${ }^{95}$

Estabelecendo diretrizes para que os órgãos ambientais procedessem ao cálculo, cobrança, aplicação, aprovação e controle de recursos advindos da compensação ambiental, ${ }^{96}$ foi editada a Resolução CONAMA 371/2006, revogando expressamente a Resolução 02/1996.

A nova Resolução previu que o órgão ambiental licenciador deverá estabelecer o grau de impacto ambiental causado pela implantação do empreendimento, fundamentado em base técnica que possa avaliar os impactos negativos e não mitigáveis aos recursos ambientais identificados no processo de licenciamento, de acordo com o EIA/RIMA. ${ }^{97}$ Contudo, para que seja estabelecido o grau do impacto, deverão ser considerados apenas os impactos causados aos recursos ambientais, excluindo os riscos

\footnotetext{
${ }^{95}$ MACIEL, Marcela Albuquerque. Op. Cit., p. 148.

${ }^{96}$ Art. $1^{\circ}$ da Resolução CONAMA 371/2006.

${ }^{97}$ Art. $2^{\circ}$ da Resolução CONAMA 371/2006.
} 
da operação do empreendimento e não podendo haver redundância de critérios. ${ }^{98}$ Assim,

(...) a Resolução torna claro que somente impactos negativos e não mitigáveis aos recursos ambientais deverão ser levados em consideração para o estabelecimento do grau de impacto do empreendimento e consequente valor da compensação ambiental. Determina, todavia, que, enquanto não estabelecida e publicada a metodologia para a definição do grau de impacto pelo órgão licenciador, o valor da compensação ambiental fica fixado em meio por cento dos custos previstos para a implantação do empreendimento. ${ }^{99}$

Para fins de cálculo do valor da compensação ambiental, a referida

Resolução trouxe nova regra de suma importância:

Art. $3^{\circ}$ Para o cálculo da compensação ambiental serão considerados os custos totais previstos para implantação do empreendimento e a metodologia de gradação de impacto ambiental definida pelo órgão ambiental competente.

$\S 1^{\circ}$ Os investimentos destinados à melhoria da qualidade ambiental e à mitigação dos impactos causados pelo empreendimento, exigidos pela legislação ambiental, integrarão os seus custos totais para efeito do cálculo da compensação ambiental.

$\S 2^{\circ}$ Os investimentos destinados à elaboração e implementação dos planos, programas e ações, não exigidos pela legislação ambiental, mas estabelecidos no processo de licenciamento ambiental para mitigação e melhoria da qualidade ambiental, não integrarão os custos totais para efeito do cálculo da compensação ambiental.

$\S 3^{\circ}$ Os custos referidos no parágrafo anterior deverão ser apresentados e justificados pelo empreendedor e aprovados pelo órgão ambiental licenciador.

Ou seja, da mesma forma que ocorria anteriormente, serão considerados os custos totais da implantação para calcular a compensação. No entanto, os parágrafos do citado dispositivo trouxeram duas mudanças relevantes. A primeira é a de que se os investimentos destinados à melhoria da qualidade ambiental e à mitigação dos impactos causados pelo empreendimento forem exigidos pela legislação ambiental, os mesmos irão integrar os custos totais do empreendimento para efeito do cálculo. Por outro lado, se estes investimentos, não forem exigidos pela lei, eles não irão integrar os custos totais para o cálculo da compensação ambiental. Tais

\footnotetext{
${ }^{98}$ Art. $2^{\circ}, \S 1^{\circ}$ da Resolução CONAMA 371/2006.

${ }^{99}$ MACIEL, Marcela Albuquerque. Op. Cit., p. 150.
} 
custos deverão ser apresentados e justificados pelo empreendedor, dependendo da aprovação pelo órgão ambiental.

Fica obrigado o empreendedor ainda a apresentar a previsão do custo total da implantação do empreendimento antes da emissão da LI, sendo garantido o sigilo de tais informações. ${ }^{100}$

Quanto ao momento do processo licenciatório em que o percentual para a compensação ambiental deverá ser estabelecido, a Resolução ora tratada prevê, que será quando da emissão da LP e apenas será da LI nos casos em que a primeira não for exigível. ${ }^{101}$ Contudo, o desembolso de tal valor não será exigido antes da LI e a determinação do quantum da compensação ambiental e a celebração de seu termo de compromisso deverão ocorrer, segundo a norma, no momento da emissão da LI. ${ }^{102}$

Vale notar que atualmente, em âmbito federal, a competência para firmar estes termos de compromisso com os empreendedores é do ICMBio, já que envolvem a execução de projetos e atribuições que cabem ao órgão gestor das unidades de conservação e não ao órgão licenciador. Caberá a este, o IBAMA no caso federal, a competência para estabelecer o grau de impacto das unidades de conservação afetadas. ${ }^{103}$

Já nos casos de ampliação ou modificação de empreendimentos já licenciados e que causem significativo dano, dependendo portanto de EIA/RIMA, a compensação deverá ser calculada com base nos custos da respectiva ampliação ou modificação.

Se, por outro lado, o empreendimento em questão já tiver efetivado seu apoio à implantação ou manutenção de uma unidade de conservação, não precisará haver a reavaliação dos valores pagos, nem precisará destinar recursos complementares, a não ser nos casos mencionados de ampliação/modificação de empreendimentos já licenciados e nos demais casos previstos no art. 19, I e II da Resolução CONAMA 237/1997. ${ }^{104}$

\footnotetext{
${ }^{100}$ Art. $4^{\circ}$ da Resolução CONAMA 371/2006.

${ }^{101}$ Art. $5^{\circ}$ da Resolução CONAMA 371/2006.

${ }^{102}$ Art. $5^{\circ}, \S 1^{\circ}$ e $\S 2^{\circ}$ da Resolução CONAMA 371/2006.

${ }^{103}$ MACIEL, Marcela Albuquerque. Op. Cit., p. 151.

${ }^{104}$ Art. $7^{\circ}$ da Resolução CONAMA 371/2006.
} 
Além das novidades mencionadas, a Resolução em comento também tratou das chamadas câmaras de compensação ambiental já previstas no Decreto 4.340/2002. Ficou estabelecido que estas câmaras, que deveriam ser instituídas pelos órgãos licenciadores, teriam o objetivo de analisar e propor a aplicação da compensação ambiental nas unidades de conservação, tanto federais, estaduais como municipais de forma a fortalecer o SNUC e promover um maior controle da aprovação e dos gastos advindos da compensação ambiental. ${ }^{105}$

Assim, o órgão gestor das unidades de conservação selecionadas deverá apresentar um plano de trabalho da aplicação dos recursos para que a referida câmara o analise e o aprove. ${ }^{106}$ Ressalte-se que somente receberão os recursos da compensação ambiental, aquelas unidades de conservação que estiverem inscritas no Cadastro Nacional de Unidades de Conservação. $^{107}$

É necessário ainda que os órgãos ambientais responsáveis pela gestão dos recursos de compensação ambiental deem publicidade à aplicação de tais recursos, atentando-se para o fato de que os estudos, projetos e atividades executadas devem ser disponibilizadas ao público, atendendo ao princípio da publicidade. ${ }^{108}$

Quando o órgão ambiental licenciador for definir as unidades de conservação a serem beneficiadas pela compensação ambiental, respeitados os critérios do art. 36 da Lei do SNUC e o art. 33 do Decreto 4.340/2002, deverá observar o seguinte: (i) se a atividade afetar diretamente uma ou mais unidades de conservação ou zonas de amortecimento, independente do grupo a que pertençam, estas deverão ser beneficiadas com recursos da compensação ambiental e (ii) se a atividade não afetar unidade de conservação ou zona de amortecimento, parte dos recursos oriundos da compensação deverá ser destinada à criação, implantação ou manutenção de

\footnotetext{
105 Art. $8^{\circ}$ da Resolução CONAMA 371/2006.

${ }^{106}$ Art. 11, § $2^{\circ}$ da Resolução CONAMA 371/2006.

${ }^{107}$ Art. $11, \S 1^{\circ}$ da Resolução CONAMA 371/2006.

${ }^{108}$ Art. 12, § único da Resolução CONAMA 371/2006.
} 
uma Unidade de Conservação do Grupo de Proteção Integral localizada, preferencialmente, no mesmo bioma e na mesma bacia hidrográfica do empreendimento licenciado. ${ }^{109}$

No caso de restarem recursos não aplicáveis, deverão ser destinados à criação, implantação o manutenção de outras unidades de conservação de proteção integral. $^{110}$

Com este intuito, o empreendedor, deverá apresentar no EIA/RIMA sugestões de unidades de conservação a serem criadas ou beneficiadas, sendo assegurado a qualquer interessado, durante o procedimento de licenciamento, o direito de sugerir outras unidades de conservação para tal finalidade. O órgão ambiental, contudo, não estará vinculado às sugestões do empreendedor ou de terceiros interessados, devendo sempre justificar sua escolha. ${ }^{111}$

Por fim, a referida Resolução destaca que os valores combinados ou já pagos não serão revalidados e não haverá a obrigação de destinação de recursos complementares constantes de acordo (temos de compromisso, TAC, contratos, etc.) ou outro documento formal firmados pelos órgão ambientais, a título de compensação ambiental. ${ }^{112}$

Embora o Decreto 4.340/2002 já previsse em seu art. 32 a criação de câmaras de compensação ambiental, com a "finalidade de analisar e propor a aplicação da compensação ambiental, de acordo com estudos ambientais realizados e percentuais definidos", esta norma apenas se concretizou com a Portaria MMA 416/2010, que estabeleceu a chamada Câmara Federal de Compensação Ambiental (CFCA), contendo as seguintes atribuições: (i) estabelecer prioridades e diretrizes para aplicação da compensação ambiental federal; (ii) avaliar e auditar, periodicamente, a metodologia e os procedimentos de cálculo da compensação ambiental; (iii) propor diretrizes necessárias para agilizar a regularização fundiária das unidades de

\footnotetext{
${ }^{109}$ Art. $9^{\circ}, \S \S 1^{\circ}$ e $2^{\circ}$ da Resolução CONAMA 371/2006.

${ }^{110}$ Art. 9, § único da Resolução CONAMA 371/2006.

${ }^{111}$ Art. $10, \S \S 1^{\circ} 2^{\circ}$ da Resolução CONAMA 371/2006.

${ }^{112}$ Art. 14 da Resolução CONAMA 371/2006.
} 
conservação; (iv) estabelecer diretrizes para elaboração e implantação dos planos de manejo das unidades de conservação; (v) deliberar, na sua esfera de competência, sob forma de resoluções, proposições e recomendações, visando o cumprimento da legislação ambiental referente à compensação ambiental federal; e (vi) elaborar seu regimento interno.

Posteriormente foi editada a Portaria Conjunta MMA/IBAMA/ICMBio 225/2011 que criou o Comitê de Compensação Ambiental Federal (CCAF), integrado por membros do MMA, IBAMA e Instituto Chico Mendes de Conservação da Biodiversidade (ICMBio). ${ }^{113}$ Dentre suas atribuições está as funções de (i) deliberar sobre a divisão e a finalidade dos recursos oriundos da compensação ambiental federal para as unidades de conservação beneficiadas ou a serem criadas, inclusive as atividades necessárias ao fortalecimento do SNUC (ii) manter registros dos termos de compromisso firmados e dos relatórios de execução dos recursos aplicados a serem fornecidos pelo órgão gestor da unidade de conservação (iii) receber do gestor da unidade de conservação documentos atestando o cumprimento das obrigações e consolidá-los para demonstrar a quitação de tais obrigações (iv) receber do gestor da unidade de conservação relatórios relacionados à auditoria, monitoria e avaliação dos recursos aplicados e (v) relatar à Câmara Federal de Compensação Ambiental sobre suas atividades. $^{114}$

Apesar da extensa evolução legislativa aqui exposta e com todo o aparto legal aplicável à compensação ambiental, ainda assim, não foi possível solucionar diversas questões acerca da aplicação deste instituto, que vão desde a controvérsia sobre sua natureza jurídica até o cálculo do valor a ser efetivamente pago pelo empreendedor.

Com vistas a solucionar estes questionamentos, foi ajuizada a Ação Direta de Inconstitucionalidade (ADI) $3378,{ }^{115}$ em 16 de dezembro de 2004, pela Confederação Nacional da Indústria (CNI), tendo por objeto

\footnotetext{
113 Art. $1^{\circ}$ da Portaria Conjunta MMA/IBAMA/ICMBio 225/2011.

${ }_{114}^{11}$ Art. $3^{\circ}$ da Portaria Conjunta MMA/IBAMA/ICMBio 225/2011.

${ }^{115}$ STF, ADI 3.378-6/DF, Rel. Ministro Carlos Britto, Brasília, 09 abril, 2008.
} 
justamente o citado art. 36 e da Lei do SNUC seus parágrafos, que será analisada a seguir.

\section{Questões Controvertidas}

\subsection{Principais questões enfrentadas atualmente pelo Supremo Tribunal Federal}

\subsubsection{Ação Direta de Inconstitucionalidade 3378-6}

Como visto, foi ajuizada ADI com vistas a questionar a constitucionalidade da compensação ambiental. Em síntese, a CNI aduziu que o art. 36 da Lei do SNUC e seus parágrafos: (i) violam o princípio da legalidade; (ii) violam o princípio da harmonia e independência dos poderes; (iii) violam o princípio da razoabilidade e da proporcionalidade; e (iv) a indenização prévia, sem prévia mensuração e comprovação da ocorrência de dano, pode configurar enriquecimento sem causa pelo Estado. $^{116}$

Em relação ao primeiro ponto, foi arguido que o parágrafo $1^{\circ}$ do art. 36, ao delegar ao órgão ambiental licenciador o poder de fixar o montante de recursos a ser aportado pelo empreendedor, tendo apenas estabelecido o valor mínimo equivalente a meio por cento dos custos totais previstos para a implantação do empreendimento ofende o princípio da legalidade (art. $5^{\circ}$, II da CRFB/1988). Isto, pois somente a lei, em sentido formal, pode criar deveres e obrigações, limitando o direito individual da parte. Assim, apenas o Poder Legislativo poderia criar regras impondo obrigações positivas ou negativas.

Ademais, alegou afronta ao princípio da legalidade administrativa (art. 37, caput da CRFB/1988), no sentido de que a administração pública só pode fazer ou deixar de fazer o que a lei, e não uma resolução de um órgão administrativo, determina.

Sobre a suposta violação ao princípio da independência e harmonia dos poderes, descreveu a autora que o dispositivo citado representa uma

\footnotetext{
${ }^{116}$ Petição inicial nos autos da ADI 3.378 (STF, ADI 3.378-6/DF, Rel. Ministro Carlos Britto, Brasília, 09 abril, 2008). p. 2.
} 
delegação ilegítima do Poder Legislativo ao Poder Executivo do poder de legislar. Tal delegação apenas seria possível se a lei estabelecesse parâmetros, limites e standards que limitassem e pautassem a ação do administrador. Como isto não ocorreu, segundo a autora, o art. 36 conteria delegação disfarçada e, portanto, inconstitucional.

No que tange o terceiro ponto da ADI ora em análise, a autora defendeu que os danos ambientais significativos, que a lei pretende sejam indenizados, não ocorrem no processo licenciamento quando é exigido o EIA/RIMA, não se justificando a cobrança da compensação ambiental. Segundo a mesma não há relação de adequação entre o fim visado e o empregado pelo legislador. De forma a defender tal tese, o argumento principal utilizado foi o de que se o EIA/RIMA não previr, no âmbito do processo de licenciamento, a eliminação e/ou mitigação dos impactos negativos significativos, a licença ambiental não será deferida. Assim, em não havendo significativo impacto ambiental, que constitui o suporte jurídico que respalda a cobrança da compensação ambiental, por que o dever de pagá-la? Veja-se, abaixo, o posicionamento da autora acerca desta questão:

Quer dizer: por que teriam os empreendedores de pagar a compensação ambiental, na potencialidade de dano significativo de seu empreendimento, se não causarão significativo impacto ambiental na operação de suas atividades, já que terão que ser eliminados ou mitigados ao máximo, nos termos do respectivo processo de licenciamento?

Na verdade, a imposição da compensação ambiental se revela absolutamente destituída de causa! ${ }^{117}$

Além disso, argumentou-se no sentindo de que ao estabelecer como base para o cálculo do valor a ser pago os custos totais previstos para a implantação do empreendimento, os dispositivos mencionados acabaram por penalizar justamente aqueles que mais investiram em equipamentos para proteção ambiental. Adicionalmente, tal valor não representa medida do dano ambiental que se pretende indenizar ou reparar, nem os recursos

\footnotetext{
${ }^{117}$ Petição Inicial nos autos da ADI 3378 (STF, ADI 3.378-6/DF, Rel. Ministro Carlos Britto, Brasília, 09 abril, 2008.). p. 20.
} 
ambientais utilizados ou impactados pelo empreendimento. Ao não se definir expressamente o que está incluído na expressão "custos totais previstos para a implantação do empreendimento", feriu-se também o princípio da segurança jurídica.

Por fim, aduziu a autora que a pré-fixação de um valor a ser pago pelo empreendedor sem a certeza da ocorrência do dano acarretaria o enriquecimento sem causa do Estado. O valor a ser pago é fixado pelo dispositivo antes de comprovar a ocorrência do dano, podendo, inclusive, este valor ser muito superior ao dano efetivamente causado. Assim, defendeu a autora, que é imprescindível a prévia ocorrência e prévia valoração dos danos para justificar a indenização requerida, sob pena do Estado locupletar-se às custas alheias.

Em 09 de abril de 2008 a referida a ADI foi julgada parcialmente procedente, por maioria de votos, restando a ementa redigida da seguinte forma:

EMENTA: AÇÃO DIRETA DE INCONSTITUCIONALIDADE. ART. 36 E SEUS $\S \S 1^{\circ}, 2^{\circ} \mathrm{E} 3^{\circ}$ DA LEI $\mathrm{N}^{\circ}$ 9.985, DE 18 DE JULHO DE 2000. CONSTITUCIONALIDADE DA COMPENSAÇÃO DEVIDA PELA IMPLANTAÇÃO DE EMPREENDIMENTOS DE SIGNIFICATIVO IMPACTO AMBIENTAL. INCONSTITUCIONALIDADE PARCIAL DO $\S 1^{\circ}$ DO ART. 36.

1. O compartilhamento-compensação ambiental de que trata o art. 36 da Lei $n^{\circ}$ 9.985/2000 não ofende o princípio da legalidade, dado haver sido a própria lei que previu o modo de financiamento dos gastos com as unidades de conservação da natureza. De igual forma, não há violação ao princípio da separação dos Poderes, por não se tratar de delegação do Poder Legislativo para o Executivo impor deveres aos administrados.

2. Compete ao órgão licenciador fixar o quantum da compensação, de acordo com a compostura do impacto ambiental a ser dimensionado no relatório EIA/RIMA.

3. $\mathrm{O}$ art. 36 da Lei $\mathrm{n}^{\circ} 9.985 / 2000$ densifica o princípio usuário-pagador, este a significar um mecanismo de assunção partilhada da responsabilidade social pelos custos ambientais derivados da atividade econômica.

4. Inexistente desrespeito ao postulado da razoabilidade. Compensação ambiental que se revela como instrumento adequado à defesa e preservação do meio ambiente para as presentes e futuras gerações, não havendo outro meio eficaz para atingir essa finalidade constitucional. Medida amplamente compensada pelos benefícios que sempre resultam de um meio ambiente ecologicamente garantido em sua higidez.

5. Inconstitucionalidade da expressão "não pode ser inferior a meio por cento dos custos totais previstos para a implantação do empreendimento", 
no $\S 1^{\circ}$ do art. 36 da Lei $n^{0} 9.985 / 2000$. O valor da compensaçãocompartilhamento é de ser fixado proporcionalmente ao impacto ambiental, após estudo em que se assegurem o contraditório e a ampla defesa. Prescindibilidade da fixação de percentual sobre os custos do empreendimento.

6. Ação parcialmente procedente. (grifos meus) $)^{118}$

Como se vê, o Supremo Tribunal Federal (STF) decidiu que a compensação ambiental é, na realidade, "um mecanismo de assunção partilhada da responsabilidade social". Apesar de parecer uma simples constatação, esta decisão concluiu um dos maiores debates travados em relação a este instrumento, qual seja: sua natureza jurídica.

\subsubsection{Natureza Jurídica}

Muito se discutiu na doutrina acerca da natureza jurídica da compensação ambiental até o advento da decisão mencionada. Contudo, de forma a obter um real entendimento do instrumento em análise no presente trabalho, faz-se necessário esmiuçar cada um dos posicionamentos previamente adotados pelos estudiosos da compensação ambiental para posteriormente retornarmos à conclusão alcançada pelo STF.

Para uma primeira corrente, a compensação ambiental teria natureza jurídica-tributária. Seus defensores argumentam que a mesma se enquadra na definição legal de tributo constante no art. $3^{\circ}$ do Código Tributário Nacional (CTN), abaixo descrito:

Art. $3^{\circ}$ Tributo é toda prestação pecuniária compulsória, em moeda ou cujo valor nela se possa exprimir, que não constitua sanção de ato ilícito, instituída em lei e cobrada mediante atividade administrativa plenamente vinculada.

Contudo, ao analisar tal hipótese de forma mais aprofundada, é possível chegar a diversos contra argumentos para esta teoria. Primeiramente, para que seja considerado tributo, os elementos essenciais que o constituem devem estar previstos em lei para permitir sua cobrança por atividade administrativa plenamente vinculada, quais sejam: sujeito

${ }^{118}$ STF, ADI 3.378-6/DF, Rel. Ministro Carlos Britto, Brasília, 09 abril, 2008. 
passivo, base de cálculo e alíquota. ${ }^{119}$ Ocorre que, no caso da compensação ambiental, os citados elementos não existem, impossibilitando sua cobrança como tributo.

Ademais, segundo Erika Bechara, ${ }^{120}$ o tributo consiste em prestação pecuniária, enquanto a compensação ambiental em obrigação de dar ou de fazer, não ensejando a transferência de valores para órgãos públicos como no caso do tributo. ${ }^{121}$

A compensação ambiental não poderia ser classificada como imposto. Isto porque um dos principais traços caracterizadores do imposto é sua livre aplicação, definidas segundo as prioridades ditadas pelo Poder Público, não precisando guardar relação com seu fato gerador. A compensação ambiental, devido à vinculação de sua receita às unidades de conservação, jamais poderiam ser aplicadas livremente. Ademais, o valor pago na compensação não é arrecadado pelo Poder Público como o imposto, mas são aplicados diretamente pelo empreendedor, no máximo podendo ingressar no Fundo de Compensação Ambiental criado pelo Ministério do Meio Ambiente e a Caixa Econômica Federal, mas ainda sim devendo ser aplicado diretamente nas unidades de conservação. ${ }^{122}$

Como empréstimo compulsório também não teria melhor sorte. Este pode ser instituído pela União para atender as despesas extraordinárias, decorrentes de calamidade pública, de guerra externa ou sua iminência ou, ainda, no caso de investimento público de caráter urgente e de relevante interessa nacional. ${ }^{123}$ Por óbvio este não é o caso da compensação ambiental, que deverá ser paga para que o empreendedor compense os danos que provocará com sua atividade e não para auxiliar a União nas

\footnotetext{
${ }^{119}$ GODOI, Marciano Seabra de. A compensação ambiental prevista na Lei 9.985/2000. In: XVI Encontro Nacional do CONPEDI. Anais. Florianópolis: Fundação Boitex, 2008. p. 4448-4467. Apud. MACIEL, Marcela Albuquerque. Op. Cit., p. 156.

${ }^{120}$ BECHARA, Erika. Op. Cit., p. 170.

${ }^{121}$ Erika Bechara faz uma ressalva no sentido de que, a depender do Estado, pode haver a possibilidade de repassar os recursos da compensação ambiental ao órgão ambiental, de forma que este proceda a sua aplicação nas Unidades de Conservação. $\mathrm{O}$ fato de haver esta faculdade dada ao empreendedor por si só já desclassifica a natureza jurídica de tributo, pois se de fato fosse tributo, tal possibilidade seria inexistente. (BECHARA, Erika. Op. Cit., p. 171).

${ }_{122}$ BECHARA, Erika. Op. Cit., p. 173.

123 Art. 148, CRFB/1988.
} 
situações mencionadas. Além do mais, uma vez paga pelo empreendedor, este não será restituído. ${ }^{124}$

Outra opção rechaçada é o caso das contribuições sociais, de intervenção no domínio econômico e de interesse das categorias profissionais ou econômicas. ${ }^{125}$ Apesar de afetada a uma finalidade específica, a compensação ambiental não deve ser considerada como uma destas modalidades porque não foi instituída com vistas ao financiamento da saúde, educação e seguridade social ou à intervenção no domínio econômico, muito menos ao atendimento de categoria profissional ou econômica. ${ }^{126}$ Como se não fosse suficiente, o art. 149 da CRFB/1988 dispõe no sentido de que a instituição destas contribuições é de competência exclusiva da União, enquanto a compensação ambiental pode ser exigida também pelos Estados e Municípios enquanto órgãos licenciadores. ${ }^{127}$

A taxa seria outra possibilidade, contudo, diferentemente dos casos acima, trata-se de espécie de tributo vinculado, ou seja, para que o Estado possa exigi-la do contribuinte, deverá fazer algo em troca. Além disso, seu fato gerador é o exercício regular do Poder de Polícia ou a utilização, efetiva ou potencial, de serviço público específico e divisível, prestado ao contribuinte ou ao menos posto a sua disposição. ${ }^{128}$ Veja-se, que a taxa pode ser de polícia ou de serviço, sendo certo que nenhuma delas se aproxima do regime da compensação ambiental.

Não poderia ser taxa de polícia, pois o licenciamento ambiental é uma atividade de polícia do Estado, tendo seu custo repassado ao empreendedor mediante cobrança de uma taxa de polícia específica. Os recursos destinados à compensação ambiental não são pagos pelo fato dos empreendedores utilizarem a máquina estatal, mas por gerarem impacto ambiental significativo e inafastável. ${ }^{129}$

\footnotetext{
${ }^{124}$ BECHARA, Erika. Op. Cit., p. 175.

${ }^{125}$ Art. 149, CRFB/1988.

${ }^{126}$ BECHARA, Erika. Op. Cit., p. 177.

${ }^{127}$ MACIEL, Marcela Albuquerque. Op. Cit., p. 158.

${ }^{128}$ Art. 145, II da CRFB/1988 c/c art. 77 do CTN.

${ }^{129}$ BECHARA, Erika. Op. Cit., p. 187.
} 
Se não pode ser considerada taxa de polícia, muito menos poderia ser considerada taxa de serviço, posto que esta apenas pode ser instituída para remunerar serviço público singular e divisível. Ou seja, onde não houver serviço público, não haverá a cobrança de taxa correspondente. Como não ocorre no licenciamento ambiental, no ato de exigência da compensação ambiental, nem na implantação de unidades de conservação um serviço público prestado pelo Estado, não há que se falar na natureza jurídica de taxa de serviço. ${ }^{130}$

Além da taxa, tem-se a contribuição de melhoria que é instituída para fazer face ao custo de obras públicas de que decorra valorização imobiliária, tendo como limite total a despesa realizada e como limite individual o acréscimo de valor que da obra resultar para cada imóvel beneficiado. $^{131}$ Ora, não há semelhança alguma com a compensação ambiental, já que o empreendedor não é obrigado a desembolsar este valor devido à valorização imobiliária decorrente de obra pública, mas em função dos impactos ambientais gerados por seu empreendimento. ${ }^{132}$

Por fim, apesar de não ser espécie tributária, tendo natureza contratual, há o preço público, também chamado de tarifa. Este consiste na remuneração de um ente estatal pela exploração ou uso de um bem público, pelo particular, ou recebimento de um serviço público não essencial. Assim, o preço público se dá na efetivação do princípio do usuário-pagador, já que este preconiza que aquele que utilizar recursos ambientais com fins econômicos deve pagar uma contribuição. ${ }^{133}$ Segundo Erika Bechara, ${ }^{134}$ é justamente isto que defendem os adeptos desta corrente, o dever do usuário de contribuir pela utilização dos recursos ambientais. Contudo, responde a referida autora que não se deve reduzir a compensação ambiental a uma contraprestação paga por quem utiliza recursos ambientais, quando sua

\footnotetext{
${ }^{130}$ Ibid. p. 189.

${ }^{131}$ Art. 81 do CTN.

${ }^{132}$ BECHARA, Erika. Op. Cit., p. 190.

${ }^{133}$ Ibid.

${ }^{134}$ Ibid. p. 192.
} 
natureza é bem mais abrangente, incluindo ainda empreendimentos que não utilizam ou exploram recursos ambientais. Em suas próprias palavras:

\begin{abstract}
Como o princípio do usuário-pagador tem por escopo garantir a quantidade e a perenidade dos recursos ambientais utilizados, acaba por incidir até mesmo quando inexiste qualquer impacto ambiental. Ora, mas se o pressuposto da compensação ambiental é justamente o impacto ambiental negativo não mitigável (e não o uso dos bens ambientais), não vemos como identificar este instituto jurídico com o princípio em apreço.

Dessa forma, esposamos nossa conclusão de que a compensação ambiental não se reveste da natureza jurídica de preço público, tampouco encontra abrigo no princípio do usuário-pagador, porque sua finalidade não é pagar ao Estado uma contraprestação pelo uso ou exploração de um bem público ou difuso; é compensar os prejuízos a serem causados ao meio ambiente, por determinados empreendimentos, que o estado-da-arte não consegue afastar. ${ }^{135}$
\end{abstract}

Ademais, a compensação ambiental pode ser eventualmente cumulada com determinado preço público, a exemplo do caso de um empreendedor que despeja efluentes em rio de domínio da União, devendo pagar à Agência Nacional de Águas valor a título de retribuição pelo seu uso, além da compensação ambiental do art. 36 da Lei do SNUC. ${ }^{136}$

Resta claro, portanto, a dificuldade de enquadrar a natureza jurídica da compensação ambiental como tributária. Passaremos agora a exposição da próxima corrente.

Para uma segunda corrente, a compensação ambiental se enquadraria na no campo da responsabilidade civil por danos ambientais futuros. Segundo esta corrente, onde se encontra grande parte da doutrina, a compensação ambiental nada mais é do que a reparação de danos futuros, ou seja, uma reparação ex ante, devida em virtude de danos não mitigáveis/não evitáveis, identificados antes de sua ocorrência concreta no processo de licenciamento ambiental da atividade. ${ }^{137}$ Como defensores desta posição encontram-se doutrinadores como Erika Bechara ${ }^{138}$, Marcelo Abelha Rodrigues ${ }^{139}$ e Solange Teles da Silva ${ }^{140}$.

\footnotetext{
${ }^{135}$ Ibid. p. 193-194.

${ }^{136}$ MACIEL, Marcela Albuquerque. Op. Cit., p. 159.

${ }^{137}$ BECHARA, Erika. Op. Cit., p. 195.

${ }^{138}$ Ibid. p. 194.

${ }^{139}$ RODRIGUES, Marcelo Abelha. Aspectos Jurídicos da Compensação Ambiental. Op. Cit.
} 
Diz-se "danos ambientais futuros", pois, na compensação ambiental do art. 36 da Lei do SNUC, o recurso financeiro é exigido do empreendedor quando ele estiver prestes a causar um dano ambiental irreversível e inevitável, verificado, portanto, antes da efetiva ocorrência do mesmo. Isto, como visto anteriormente, é diferente da compensação de danos "clássica", exigida do empreendedor quando o meio ambiente já sofreu um impacto irreversível, posteriormente então à verificação do dano. ${ }^{141}$

O problema surge quando da análise da responsabilidade civil. Isto porque, como se sabe, a responsabilidade civil é um instituto que tem como objetivo impor ao causador de um dano o dever de repará-lo. Para isto, um de seus pressupostos é a ocorrência efetiva e concreta de um dano, chamado pela doutrina de dano certo e atual. Consequentemente, não há que se falar em reparação se não houver dano.

Por isso, há quem defenda uma responsabilidade civil preventiva, que atue antes da ocorrência do dano, ao simplesmente colocar o meio ambiente em risco, devido à importância do bem protegido, como se vê através do posicionamento de Gabriel Luis Bonora Vidrih Ferreira e Solange Teles da Silva ${ }^{142}$ :

\begin{abstract}
A inserção de deveres ambientais, de mitigação e de compensação, realizada anteriormente ao exercício da atividade, acrescenta os caracteres do princípio da prevenção e precaução à realização de empreendimentos, permite que a conservação do meio ambiente faça parte do processo produtivo e cria para o agente econômico a preocupação em produzir o menor grau de prejuízo ao meio ambiente. Destaca-se, assim, que a importância da integridade do bem protegido e a dificuldade em se estabelecer medidas apropriadas para sua reparação incentivaram o surgimento de uma versão preventiva de responsabilidade civil, com fundamento no princípio conservacionista, no princípio do poluidor-usuário, poluidor-pagador e no princípio de precaução.
\end{abstract}

Há ainda quem defenda que, apesar de não se filiar ao posicionamento de que o risco é reparável, a ocorrência de danos futuros

\footnotetext{
${ }^{140}$ FERREIRA, Gabriel; SILVA, Solange. Op. Cit.

${ }^{141}$ BECHARA, Erika. Op. Cit., p. 195.

${ }^{142}$ FERREIRA, Gabriel; SILVA, Solange. Op. Cit., p. 134.
} 
certos é. É este o entendimento de Erika Bechara ${ }^{143}$, como pode ser verificado abaixo:

\begin{abstract}
De nossa parte, embora ainda nos mantenhamos firmes no entendimento de que a responsabilidade civil tem como elemento primordial o dano, de sorte a não acreditarmos na responsabilidade civil em função dos riscos - para estes continuamos aplicando o princípio da prevenção e da precaução, inclusive por meio de liminares em ações civil públicas ambientais ou por meio de ações inibitórias e ações de remoção de ilícito -, somos da opinião de que o sistema da responsabilidade civil comporta a reparação de danos futuros, ainda não causados, porém de ocorrência certa, devidamente antevista. Danos futuros não são meros riscos, que podem ou não concretizar-se. São danos certos, porém ainda não concretizados.
\end{abstract}

Contudo, esta corrente também pode ser contraposta segundo o posicionamento de Marcela Maciel. Considerando que a responsabilidade civil se pauta em três pressupostos básicos (existência de dano, culpabilidade e relação de causalidade), quando estes requisitos estão ausentes, ou quando forem postergados para um futuro nem sempre certo, pode-se ainda continuar tratando a compensação ambiental no âmbito da responsabilidade civil?

Este questionamento é relevante, visto que mesmo afastando-se a culpabilidade em decorrência da consagração da responsabilidade civil objetiva por danos ambientais pela Lei 6.938/198 (Política Nacional do Meio Ambiente), restam ainda a existência do dano e do nexo de causalidade. Os defensores da corrente ora em análise, como visto, transferem o dano para o futuro, e a certeza de sua configuração decorreria do EIA. ${ }^{144}$

Entretanto, ao fazer isso, o que esta corrente acaba promovendo são estimativas ou presunções fáticas da ocorrência de danos, cuja aferição é difícil e incerta, fugindo do âmbito da responsabilidade civil. No que tange o nexo causal, este também se afigura de difícil configuração, uma vez que o dano ocorrerá futuramente. Sendo assim, acaba-se por afastar os dois elementos da responsabilidade civil que restavam, o que leva a conclusão

\footnotetext{
${ }^{143}$ BECHARA, Erika. Op. Cit., p. 201.

${ }^{144}$ MACIEL, Marcela Albuquerque. Op. Cit., p. 163.
} 
de que a resposta para a pergunta realizada acima é não, ante a dificuldade de se manter a coerência interna da teoria. ${ }^{145}$

Outro problema relativo a esta teoria ressaltado pela referida autora é a discussão quanto à valoração econômica do eventual dano a ser reparado, mesmo que de forma antecipada. Trata-se, desta vez, de um problema prático. Explica a autora que, apesar não ser simples valorar a biodiversidade, há métodos desenvolvidos economicamente para realizar este cálculo. Contudo,

\begin{abstract}
A avaliação dos impactos e possíveis danos a serem causados por um empreendimento ou atividade, por seu turno, é algo diverso da valoração econômica desses danos. A verificação do potencial impacto ambiental de um empreendimento ou atividade, em comparação com outros, é uma situação que sempre foi passível de ser aferida, levando-se em conta os respectivos EIAs. O entendimento de que a compensação ambiental deve corresponder à exata valoração econômica de possível danos a serem causados pela atividade ou empreendimento atribui ao licenciamento ambiental, e ao EIA, uma complexidade ainda maior do que a já existente. Com essa compreensão, corre-se o risco de perpetuar discussões técnicas e jurídicas quanto aos valores calculados e despendidos a título de compensação ambiental - quando das licenças prévia e de instalação - e sua correspondência com a valoração econômica do dano a ser futuramente caracterizado. ${ }^{146}$
\end{abstract}

Outrossim, este entendimento de que a compensação ambiental corresponde a reparação de danos futuros, pode acabar gerando discussões quanto à responsabilização futura destes danos, sob o argumento de duplicidade de fundamentos, o que levaria ao risco do dano ambiental restar sem reparação. Lembra a autora que, caso seja constatado posteriormente dano ambiental não previsto ou não compensado, responderá o empreendedor de forma objetiva por sua recuperação, tenha ou não pago a compensação ambiental do art. 36 da Lei do SNUC. ${ }^{147}$

\title{
3.1.1.2. Decisão da ADI 3378-6
}

\footnotetext{
${ }^{145}$ Ibid. p. 165.

${ }^{146}$ Ibid. p. 166-167.

${ }^{147}$ Ibid. p. 167.
} 
Sem aprofundar a discussão apresentada acerca da natureza jurídica da compensação ambiental, o Ministro Relator Carlos Ayres Britto ${ }^{148}$ decidiu que o art. 36 da Lei do SNUC é uma "forma de compartilhamento de despesas com as medidas oficiais de específica prevenção ante empreendimentos de significativo impacto ambiental". Foi o que denominou de "compartilhamento-compensação".

$\mathrm{O}$ referido ministro entendeu ainda que tal dispositivo densifica o princípio do usuário-pagador, significando um mecanismo de assunção da responsabilidade social pelos custos ambientais derivados da atividade econômica. $\mathrm{O}$ fundamento utilizado para este entendimento foi baseado nos ensinamentos de Paulo Affonso Leme Machado, já tratado no presente trabalho no item 1.2.

Vê-se, portanto, como não foi adotada nenhuma das correntes expostas previamente, mas sim um novo posicionamento, deixando para trás as naturezas jurídicas de tributo e responsabilidade civil. Observe-se que a natureza jurídica de tributo ${ }^{149}$ não foi sequer cogitada pelo STF.

Vale notar que Édis Milaré, ${ }^{150}$ baseando-se em análise realizada por Priscila Santos Artigas, mudou de posição em relação à natureza jurídica da compensação ambiental após o julgamento da ADI em análise, como podese ver a seguir:

Diante desse posicionamento [do Ministro Carlos Ayres Britto no julgamento da ADIn n. 3378] e avaliando melhor o tema, acabamos por compreender, conforme detida análise realizada por Priscila Santos Artigas, que a compensação ambiental

\footnotetext{
${ }^{148}$ Voto do Ministro Relator Carlos Ayres Britto na decisão da ADI 3378-6 (STF, ADI 3.3786/DF, Rel. Ministro Carlos Britto, Brasília, 09 abril, 2008).

${ }^{149}$ O Instituto Brasileiro de Petróleo e Gás (IBP), que atuou como amicus curiae na ADI 3378, defendeu o caráter tributário da compensação ambiental, mais especificamente sendo esta uma CIDE (contribuição de intervenção no domínio econômico). Neste sentido, veja-se manifestação de fls. 201 a 237, na qual o mesmo alega que a compensação ambiental não está vinculada ao dano ambiental a ser reparado, mas, sim, ao montante despendido pelo empreendedor na instalação do negócio. Assim, segundo o IBP, seria justo destacar que no plano constitucional, a instituição de uma contribuição de intervenção no domínio econômico propriamente dita deve ter como base um setor econômico que esteja em desconformidade com os princípios da ordem econômica (art. 170 da CRFB/1988). Quando isto ocorre, a União deverá intervir. Contudo, o mesmo faz uma ressalva, no sentido de que para que a compensação ambiental seja considerada como CIDE, sua criação deve estar prevista na CRFB/1988, dependendo, portanto, da edição de emenda constitucional, bem como respeitar a todos os princípios constitucionais tributários, o que não ocorre na hipótese.

${ }^{150}$ MILARÉ, Édis. Op. Cit., p. 1244-1245.
} 
se trata de espécie do gênero medidas compensatórias, as quais podem ter naturezas jurídicas diversas. (...) E, especificamente em relação à compensação ambiental da Lei do SNUC, lhe assiste razão ao defender que se trata, da mesma forma que compreendeu o STF no julgamento da ADIn 3378, de exação sem uma natureza jurídica específica, mas que está cunhada em um objetivo, ou em uma funcionalidade, qual seja, o compartilhamento de despesas.

(...)

Nesse sentido acabamos por modificar posição anterior sobre a natureza tributária da compensação ambiental, na linha preconizada pela autora: "Por conseguinte, embora logicamente construídas, vê-se que ficam superadas as teorias que pretenderam enquadrar a compensação ambiental - e, por consequência, todas as medidas compensatórias - em uma categoria jurídica estanque, vinculada a um determinado ramo do direito. Isso ocorre, como se verá logo a seguir, pois, ao tratar de regras protetoras do meio ambiente, é preciso, de um lado, focar na sua funcionalidade e não sua natureza jurídica, e, por outro lado, não se pode mais conceber a sua fixação neste ou naquele ramo do direito. Na verdade, as normas ambientais, buscando alcançar os seus objetivos, ou meramente a sua funcionalidade, atravessam, como uma linha diagonal, praticamente todos os ramos do direito e, daí, a sua característica de transversalidade".

Outro ponto relevante da decisão que merece ser destacado foi o fato de que os ministros consideraram que o "compartilhamento-compensação ambiental" do art. 36 da Lei do SNUC não representa ofensa ao princípio da legalidade, pois foi a própria lei que previu o modo de financiamento dos gastos com as unidades de conservação, nem ao princípio da separação de poderes, por não se tratar de delegação do Poder Legislativo para o Executivo impor deveres aos administrados. Ademais, entenderam não haver desrespeito ao princípio da razoabilidade, uma vez que este instrumento se revela adequado à defesa e preservação do meio ambiente para as presentes e futuras gerações, não havendo outro meio eficaz para atingir tal finalidade. Ou seja, rejeitaram os principais argumentos da inicial desta ADI, entendendo ser a compensação ambiental constitucional.

Contudo, decidiram pela inconstitucionalidade da expressão "não pode ser inferior a meio por cento dos custos totais previstos para a implantação do empreendimento" constante do parágrafo $1^{\circ}$ do dispositivo em questão, concluindo que o valor a ser pago "deve ser fixado proporcionalmente ao impacto ambiental, após estudo em que se assegurem o contraditório e a ampla defesa. Prescindibilidade da fixação de percentual sobre os custos do empreendimento". 
Assim, por maioria de votos, esta foi a solução alcançada pelos ministros do STF após longo debate que não cabe tratar aqui, vencido o Ministro Marco Aurélio, que pretendia declarar a inconstitucionalidade de todos os dispositivos impugnados, entendendo haver ofensa ao art. 225, parágrafos $2^{\circ}$ e $3^{\circ}$ da $C R F B / 1988$, e o Ministro Joaquim Barbosa, que julgou improcedente a ação, propondo interpretação conforme, sem redução de texto para fixar a compensação em $0,5 \%$.

Não se pode olvidar, contudo, que, apesar da ementa do acórdão não ter determinado a exclusão do texto referente ao "percentual", restaram dúvidas a respeito da sua permanência no dispositivo impugnado, já que o corpo do acórdão fez referência à sua retirada do texto do diploma legal. Em seu voto, que foi acolhido pelo Tribunal Pleno do STF, o Ministro Menezes Direito sugeriu que fosse retirado termo "percentual", entretanto, ao lavrar-se a ementa do acórdão constou apenas que o texto retirado é: "não pode ser inferior a meio por cento dos custos totais previstos para a implantação do empreendimento". ${ }^{151}$

Diante desta omissão e de outras contradições do acórdão, foram opostos Embargos de Declaração pelo Presidente da República ${ }^{152}$ e pela Confederação Nacional da Indústria $(\mathrm{CNI})^{153}$. O Presidente da República requereu em seus embargos que (i) fosse declarado que apenas a fixação de percentual mínimo foi considerada inconstitucional e que seria possível considerar os custos totais para a implantação do empreendimento no cálculo da compensação ambiental; (ii) que fossem modulados os efeitos da decisão para declarar os efeitos da inconstitucionalidade a partir do prazo mínimo de seis meses ou outro maior para licenciamentos que viessem a ser iniciados ou, alternativamente, para declarar os efeitos da inconstitucionalidade apenas a partir do trânsito em julgado da decisão, ou seja, efeitos ex nunc para licenciamento que viessem a ser iniciados.

\footnotetext{
${ }^{151}$ Ibid. p. 1240.

${ }^{152}$ Embargos de Declaração opostos pelo Presidente da República nos autos da ADI 3378 (STF, ADI 3.378-6/DF, Rel. Ministro Carlos Britto, Brasília, 09 abril, 2008), p. 412-459.

${ }^{153}$ Embargos de Declaração opostos pela CNI nos autos da ADI 3378 (STF, ADI 3.378-6/DF, Rel. Ministro Carlos Britto, Brasília, 09 abril, 2008), p. 468-471.
} 
Por sua vez, a CNI requereu que (i) fosse confirmando que a nova redação do parágrafo $1^{\circ}$ do art. 36 não é auto-aplicável e (ii) que, alternativamente, na hipótese de o STF entender ser auto-aplicável, que os efeitos da decisão fossem modulados para determinar que a declaração de inconstitucionalidade somente tivesse eficácia a partir de 12 meses contados do transito em julgado ou da publicação de uma nova regulamentação do parágrafo $1^{\circ}$ do art. 36 da Lei do SNUC, consubstanciada em nova metodologia, caso viesse a ocorrer antes do prazo requerido.

Note-se que os questionamentos trazidos nos mencionados embargos são de suma importância para que se possa entender e aplicar a compensação ambiental de forma correta e justa. Para que isto possa ser feito, é imprescindível que o STF esclareça, basicamente, se o termo "percentual" realmente foi excluído do dispositivo legal e se a decisão se aplica ex nunc, vigorando desde a vigência da norma ou da publicação da decisão.

Édis Milaré, baseando-se em artigo publicado no Jornal Valor Econômico pelo Dr. Luiz Fernando Villares, Consultor Jurídico do Ministério do Meio Ambiente (MMA), fez importante ressalva no sentido de que se o STF considerasse que a decisão atinge situações já consolidadas, iria trazer uma grande insegurança jurídica:

\begin{abstract}
Abrir-se-ia o questionamento e a revisão administrativa e judicial de todas as compensações ambientais já pactuadas e desembolsadas. $\mathrm{O}$ passivo administrativo ambiental exigiria imediatamente recursos materiais e servidores tão escassos. Para que isso não aconteça, a Advocacia Geral da União (AGU) demonstrou, por meio de um recurso aos ministros do Supremo, que os efeitos da decisão, se considerados retroativos, podem atingir a reavaliação de R\$ 470 milhões só em recursos federais. Estados e municípios serão atingidos em grau mais elevado, já que a regra é o licenciamento ambiental ser por eles realizado. ${ }^{154}$
\end{abstract}

Apesar da notada relevância da matéria, o STF até a data de término do presente trabalho (novembro de 2013) ainda não julgou os referidos embargos, restando pendentes tais questionamentos. Recentemente,

\footnotetext{
${ }^{154}$ MILARÉ, Édis. Op. Cit., p. 1240.
} 
contudo, em 26 de junho do presente ano, houve a substituição do relator para o Ministro Luis Roberto Barroso.

$\mathrm{Na}$ prática, a decisão do STF, apesar de reconhecer a constitucionalidade da compensação ambiental, acabou ensejando maior insegurança jurídica em relação à sua aplicação. ${ }^{155}$ Até que os embargos sejam julgados, os questionamentos mencionados restarão em aberto, trazendo graves prejuízos à funcionalidade deste instrumento e à proteção ambiental, como se verificará adiante.

\subsubsection{Reclamação 8465}

Em 14 de maio de 2009, quase um ano depois do julgamento da ADI, foi publicado o Decreto Federal 6.848/2009, impondo uma nova metodologia de cálculo da compensação ambiental, segundo a qual se aplicaria o percentual máximo de $0,5 \%$ do valor do empreendimento para atingir o valor a ser pago. Confira-se abaixo, as alterações trazidas pelo novo decreto, que modificou os arts. 31 e 32, e acrescentou os arts. 31-A e B ao Decreto 4.340/2002:

Art. 31. Para os fins de fixação da compensação ambiental de que trata o art. 36 da Lei $\mathrm{n}^{\mathrm{o}}$ 9.985, de 2000, o Instituto Brasileiro do Meio Ambiente e dos Recursos Naturais Renováveis - IBAMA estabelecerá o grau de impacto a partir de estudo prévio de impacto ambiental e respectivo relatório EIA/RIMA, ocasião em que considerará, exclusivamente, os impactos ambientais negativos sobre o meio ambiente.

$\S 1^{\circ} \mathrm{O}$ impacto causado será levado em conta apenas uma vez no cálculo.

$\S 2^{\circ} \mathrm{O}$ cálculo deverá conter os indicadores do impacto gerado pelo empreendimento e das características do ambiente a ser impactado.

$\S 3^{0}$ Não serão incluídos no cálculo da compensação ambiental os investimentos referentes aos planos, projetos e programas exigidos no procedimento de licenciamento ambiental para mitigação de impactos, bem como os encargos e custos incidentes sobre o financiamento do empreendimento, inclusive os relativos às garantias, e os custos com apólices e prêmios de seguros pessoais e reais.

$\S 4^{\circ}$ A compensação ambiental poderá incidir sobre cada trecho, naqueles empreendimentos em que for emitida a licença de instalação por trecho.

Art. 31-A. O Valor da Compensação Ambiental - CA será calculado pelo produto do Grau de Impacto - GI com o Valor de Referência - VR, de acordo com a fórmula a seguir:

${ }^{155}$ MACIEL, Marcela Albuquerque. Op. Cit., p. 192. 
CA = VR x GI, onde:

CA = Valor da Compensação Ambiental;

VR = somatório dos investimentos necessários para implantação do empreendimento, não incluídos os investimentos referentes aos planos, projetos e programas exigidos no procedimento de licenciamento ambiental para mitigação de impactos causados pelo empreendimento, bem como os encargos e custos incidentes sobre o financiamento do empreendimento, inclusive os relativos às garantias, e os custos com apólices e prêmios de seguros pessoais e reais; $\mathrm{e}$

GI = Grau de Impacto nos ecossistemas, podendo atingir valores de 0 a $0,5 \%$.

$\S 1^{\circ}$ O GI referido neste artigo será obtido conforme o disposto no Anexo deste Decreto.

§ $2^{\circ}$ O EIA/RIMA deverá conter as informações necessárias ao cálculo do GI.

$\S 3^{0}$ As informações necessárias ao calculo do VR deverão ser apresentadas pelo empreendedor ao órgão licenciador antes da emissão da licença de instalação.

$\S 4^{\circ}$ Nos casos em que a compensação ambiental incidir sobre cada trecho do empreendimento, o VR será calculado com base nos investimentos que causam impactos ambientais, relativos ao trecho.

Art. 31-B. Caberá ao IBAMA realizar o cálculo da compensação ambiental de acordo com as informações a que se refere o art. 31-A.

$\S 1^{\circ}$ Da decisão do cálculo da compensação ambiental caberá recurso no prazo de dez dias, conforme regulamentação a ser definida pelo órgão licenciador.

$\S 2^{\circ} \mathrm{O}$ recurso será dirigido à autoridade que proferiu a decisão, a qual, se não a reconsiderar no prazo de cinco dias, o encaminhará à autoridade superior.

$\S 3^{\circ} \mathrm{O}$ órgão licenciador deverá julgar o recurso no prazo de até trinta dias, salvo prorrogação por igual período expressamente motivada.

$\S 4^{\circ}$ Fixado em caráter final o valor da compensação, o IBAMA definirá sua destinação, ouvido o Instituto Chico Mendes de Conservação da Biodiversidade Instituto Chico Mendes e observado o $\S 2^{\circ}$ do art. 36 da Lei ${ }^{\circ}{ }^{9} .985$, de 2000.

Art. 32. Será instituída câmara de compensação ambiental no âmbito do Ministério do Meio Ambiente, com a finalidade de:

I - estabelecer prioridades e diretrizes para aplicação da compensação ambiental;

II - avaliar e auditar, periodicamente, a metodologia e os procedimentos de cálculo da compensação ambiental, de acordo com estudos ambientais realizados e percentuais definidos;

III - propor diretrizes necessárias para agilizar a regularização fundiária das unidades de conservação; e

IV - estabelecer diretrizes para elaboração e implantação dos planos de manejo das unidades de conservação. (grifos meus).

Inicialmente, vale destacar que os arts. 33 e 34, já analisados no presente trabalho, foram mantidos com sua redação original. Contudo, uma primeira diferença trazida pelo novo Decreto foi que o caput do art. 31 e o art. 31-B passaram a se referir somente ao IBAMA e não ao órgão licenciador como fazia anteriormente. Esta alteração iniciou uma discussão 
quanto à aplicação restrita do Decreto no âmbito federal, o que dificultaria ainda mais a padronização normativa e procedimental dos órgãos licenciadores do SISNAMA. ${ }^{156}$

Outra diferença que pode ser apontada é no que tange às câmaras de compensação ambiental que, conforme nova redação do art. 32, passou a ter finalidades e objetivos mais amplos no âmbito do Ministério do Meio Ambiente.

Devido a tais alterações, questionamentos surgiram em relação à eventual derrogação parcial da Resolução CONAMA 371/2006 pelo Decreto 6.848/2009, no que se refere ao IBAMA, podendo ainda ser aplicada aos estados e municípios. Assim, poderia se arguir que essas alterações promovidas pelo Decreto trouxeram prejuízo ao funcionamento do sistema, pois significa uma perda da unicidade na aplicação da regulamentação da Lei do SNUC. ${ }^{157}$

A novidade mais marcante, contudo, foi a limitação do valor da compensação ambiental em no máximo $0,5 \%$ do custo do empreendimento, conforme metodologia trazida pelo art. 31-A e seu anexo, com as devidas exceções do parágrafo $3^{\circ}$ do art. 31 , o que culminou no ajuizamento de Reclamação em face do Decreto 6.848/2009, pelo Instituto Socioambiental (ISA) e a Amigos da Terra - Amazônia Brasileira em 17 de junho de 2009.

$\mathrm{O}$ argumento central da Reclamação foi o de que o referido Decreto contrariou o entendimento manifestado pelo STF no julgamento da ADI 3378-6. Alegou-se que, embora o Decreto não tenha o texto idêntico ao da regra anteriormente declarada inconstitucional, traz em seu conteúdo a mesma regra afastada pela ADI, já que fixa o montante da compensação ambiental a partir do valor do empreendimento. A diferença, contudo, é a de que o Decreto transformou o que antes era um piso em teto, mas continua tendo como base de referencia o valor do empreendimento. É o argumento que se extrai do texto da inicial parcialmente transcrito a seguir:

\footnotetext{
${ }^{156}$ Ibid. p. 196.

${ }^{157}$ Ibid.
} 
Ora, não é preciso um raciocínio muito complexo para se depreender que o ato normativo decretado pelo Presidente da República afronta diretamente a decisão dessa Corte, na medida em que, ao estabelecer um teto para o valor da compensação, e ainda mais baseado nos custos do empreendimento, desconsiderou toda a argumentação levada a cabo quando do julgamento da ADI 3378 que afirmava que o montante de recursos há de ser compatível e proporcional ao grau de impacto ambiental e não ao valor da obra.

Ou seja, a inconstitucionalidade do dispositivo do decreto ora impugnado é idêntica àquela já declarada, com a diferença de que, antes, o valor da compensação não poderia ser inferior a $0,5 \%$ do valor dos investimentos da obra, e agora não podem ser superior a essa porcentagem, mesmo que os impactos do empreendimento demandem uma compensação em patamar superior a esse. ${ }^{158}$

Ademais, os autores da Reclamação destacaram que, ainda que a ADI 3378-6 não tenha transitado em julgado, a mesma já estaria operando plenos efeitos no mundo jurídico, na medida em que, conforme art. 27 da Lei Federal 9.868/1999, o Tribunal deveria declarar expressamente se a decisão ficará suspensa até o trânsito em julgado, o que não ocorreu no caso em tela. Por este motivo, consideraram os autores que a decisão da mencionada ADI já seria eficaz, devendo ter sua autoridade resguardada. Segundo as mesmas, a decisão continuaria sendo eficaz, mesmo que pendente o julgamento dos embargos de declaração, já que este recurso não é dotado de efeito suspensivo capaz de impedir a imediata produção de efeitos da decisão embargada.

Assim, requereram (i) liminarmente, que fosse suspensa a eficácia do artigo $2^{\circ}$ e anexos do Decreto 6.848/2009, ante o risco de aplicação imediata de norma já declarada inconstitucional aos inúmeros empreendimentos em fase de implementação no país e (ii) no mérito, que fossem cassados os referidos dispositivos por desafiar a autoridade do acórdão proferido na ADI 3378, de acordo com os arts. 17 da Lei 8.038/90 e 161, inciso III, do Regimento Interno do STF.

Em 03 de novembro de 2009, o Ministro Marco Aurélio proferiu decisão indeferindo a liminar ao entender que "a interposição de embargos declaratórios gera a presunção de não haver o aperfeiçoamento da prestação

\footnotetext{
${ }^{158}$ Petição Inicial nos autos da Reclamação (STF, Rcl 8465/DF, Rel. Ministro Marco Aurélio, Brasília), p. 13.
} 
jurisdicional". Ademais, o referido ministro considerou o fato de que o Supremo afastou "o piso referente ao ressarcimento por possível dano ambiental quando, na verdade, o decreto envolvido na espécie versa limite". 159

Ressalte-se que o próprio STF já decidiu anteriormente que a interposição de embargos de declaração não impede a implementação da decisão, como se verifica no caso abaixo ementado:

AÇÃO DIRETA DE INCONSTITUCIONALIDADE. EMBARGOS DE DECLARAÇÃO. CUMPRIMENTO DA DECISÃO. 1. Desnecessário o trânsito em julgado para que a decisão proferida no julgamento do mérito em ADI seja cumprida. Ao ser julgada improcedente a ação direta de inconstitucionalidade ADI n ${ }^{\circ} 2.335$ - a Corte, tacitamente, revogou a decisão contrária, proferida em sede de medida cautelar. Por outro lado, a lei goza da presunção de constitucionalidade. Além disso, é de ser aplicado o critério adotado por esta Corte, quando do julgamento da Questão de Ordem, na ADI 711 em que a decisão, em julgamento de liminar, é válida a partir da data da publicação no Diário da Justiça da ata da sessão de julgamento. 2. A interposição de embargos de declaração, cuja consequiência fundamental é a interrupção do prazo para interposição de outros recursos (art. 538 do CPC), não impede a implementação da decisão. Nosso sistema processual permite o cumprimento de decisões judiciais, em razão do poder geral de cautela, antes do julgamento final da lide. 3. Reclamação procedente. (grifos meus). ${ }^{160}$

Determinada a oitiva do Procurador-Geral da República, os autos foram encaminhados com vista à PGR em 18 de fevereiro de 2010 e, apenas recentemente, em 24 de julho de 2013, ou seja aproximadamente mais de dois anos depois, foi juntado o parecer do mesmo pela improcedência da Reclamação, ao considerar que:

15. Não assentou a Corte, a princípio, a vedação pura e simples à inclusão do valor do empreendimento no cálculo do valor da compensação. $\mathrm{O}$ decreto agora trazido a exame da Corte traz fórmula que, embora inclua o custo do empreendimento no cálculo para se chegar ao valor da compensação, leva em consideração elemento (GI = grau de impacto) relacionado diretamente ao dano ocasionado ao meio ambiente. Observe-se que o denominado 'GI' será calculado com base nas informações contidas no EIA/RIMA, como disposto no parágrafo $2^{\circ}$ do art. 31-A acrescido pelo decreto impugnado, o que parece consentâneo com o julgado da Corte.

\footnotetext{
${ }^{159}$ Decisão nos autos da Reclamação 8465 (STF, Rcl 8465/DF, Rel. Ministro Marco Aurélio, Brasília), p. 216.

${ }^{160}$ STF, Rcl 2676, Rel. Ministra Ellen Gracie, Tribunal Pleno, Brasília, 26 de jun. 2004.
} 
16. Em verdade, o exame comparativo entre o ato questionado e o acórdão indicado acaba por levar à conclusão de que não há a necessária identidade material entre eles, ao menos não com força suficiente a autorizar o uso de via estreita como a da reclamação. $\mathrm{O}$ reclamante busca afastar a constitucionalidade do decreto impugnado com a utilização de paradigma que não se amolda com perfeição - sequer os seus fundamentos - à sua pretensão. ${ }^{161}$

Em 29 de julho do corrente ano, os autos foram para conclusão do Relator, aonde se encontram até o presente momento (novembro de 2013).

Vale observar, que, em tese, não haveria problema na fixação de um limite à internalização de custos a ser exigida, como ressalta Marcela Maciel $^{162}$, ainda que seja discutível se seria adequado o estabelecimento de um valor superior ao fixado. A questão primordial, ao revés, estaria na possibilidade de se chegar a um valor zero, já que apenas estaria previsto um teto e não um piso. Assim, em determinados casos, poderia não se promover a internalização alguma dos impactos não mitigáveis à biodiversidade. De qualquer modo, frisa a autora, uma vez fixado limite para a compensação ambiental, caso sejam verificados impactos não mitigáveis não compensados por esses valores, deverá o órgão ambiental indicar outras medidas compensatórias específicas, devendo eventual dano não previsto e/ou compensado ser objeto de responsabilização civil. ${ }^{163} \mathrm{O}$ importante é não permitir que esta nova regra signifique um retrocesso da compensação ambiental prevista na Lei do SNUC e, consequentemente, um prejuízo ao meio ambiente ecologicamente equilibrado.

\subsection{Aplicação prática da compensação ambiental}

\subsubsection{Esfera federal}

O Congresso Nacional solicitou ao Tribunal de Contas da União (TCU), por meio do Requerimento 29/2012, do senador Rodrigo Rollemberg, originada da Comissão de Meio Ambiente, Defesa do Consumidor e Fiscalização e Controle (CMA) do Senado Federal, a

\footnotetext{
${ }^{161}$ Parecer da Procuradoria Geral da República nos autos da Reclamação 8465 (STF, Rcl 8465/DF, Rel. Ministro Marco Aurélio, Brasília), p. 229-230.

${ }_{162}^{162}$ MACIEL, Marcela Albuquerque. Op. Cit., p. 198-199.

${ }^{163}$ Ibid. p. 199.
} 
"avaliação operacional sobre a aplicação e fiscalização dos recursos da Compensação Ambiental, criada pela Lei 9.985/00, destacando a aplicação dos valores dos últimos dez anos e avaliando a eficiência e a eficácia dos programas de governo por eles assistidos".

A solicitação desta auditoria operacional foi autorizada por meio do Acórdão 2708/2012-TCU-Plenário, em sessão de 03 de outubro de 2012. Tal auditoria conduzida pela SecexAmbiental, abrangeu o MMA, o Ibama, o ICMBio e a Caixa Econômica Federal (Caixa), instituição responsável pela gestão financeira dos recursos oriundos da compensação ambiental, depositados pelos empreendedores em contas escriturais.

Sendo assim, na sessão ordinária do TCU do dia 17 de julho de 2013, foi analisado o Processo TC 014.293/2012-9, no qual foi apresentado o resultado da mencionada auditoria, e proferido o Acórdão 1853/2013-TCUPlenário $^{164}$.

Impende ressaltar que não cabe analisar neste trabalho todo o conteúdo do Processo TC 014.293/2012-9 e da auditoria operacional realizada, mas tão somente seu resultado, com o intuito de averiguar como ocorreu a aplicação e fiscalização dos recursos da compensação ambiental em âmbito federal, levando em consideração sua evolução normativa e os processos judiciais ora em tramitação relativos ao tema.

Inicialmente, nos objetivos e escopo da auditoria foi constatado que:

As análises desenvolvidas durante a fase de planejamento dos trabalhos indicaram que os principais problemas que têm afetado a efetividade na aplicação dos recursos da compensação ambiental, no intuito de conservação da biodiversidade e de fortalecimento do Snuc, dizem respeito à normatização do instituto da $\mathrm{CA}$, que tem sofrido alterações desde a sua criação, bem assim à paralisação no cálculo e na arrecadação desses recursos, compreendendo os anos de 2007 a 2009, em face dessas alterações e da impetração da Ação Direta de Inconstitucionalidade (ADI) 3378/2008, por parte da Confederação Nacional da Indústria (CNI).

Ademais a ausência de controle (auditoria e monitoramento) quanto à aplicação dos recursos de CA, previsto no art. 3o, VI, da Portaria conjunta

\footnotetext{
164 Acórdão 1853/2013-TCU-Plenário, disponível em: http://portal2.tcu.gov.br/portal/page/portal/TCU/imprensa/noticias/noticias arquivos/014.2932012-9\%20(Compensacao\%20Ambiental).pdf. Acesso em 25.10.2013.
} 
MMA/Ibama/ICMBio 225, de 30/6/2011, quer no nível federal quer nos níveis estaduais e municipais tem contribuído para que a baixa na condicionante da CA não seja efetuada. ${ }^{165}$

O problema ficou então formulado da seguinte forma:

Problema: descontinuidade na valoração, destinação, arrecadação e aplicação dos recursos da compensação ambiental, em razão das constantes alterações nos normativos ao longo do período analisado, assim como a precariedade das ações de controle (fiscalizações e monitoramento), podem comprometer o instituto da CA como instrumento de implementação do Snuc.

1a questão: em que medida a sistemática de valoração e destinação dos recursos da CA (últimos 10 anos) tem contribuído para a implantação e a manutenção de unidades de conservação do Grupo de Proteção Integral?

2a questão: em que medida a sistemática de arrecadação e aplicação/execução dos recursos da CA (últimos 10 anos) tem contribuído para a implantação e a manutenção de unidades de conservação do Grupo de Proteção Integral?

3a questão: em que medida os controles instituídos para a verificação da aplicação dos recursos da CA tem contribuído para a efetiva implantação e manutenção das unidades de conservação do Grupo de Proteção Integral? ${ }^{166}$

Os estudos foram realizados nos estados de Minas Gerais, Rio de Janeiro, São Paulo e Piauí, no período de 18 de fevereiro a $1^{\circ}$ de março de 2013, sendo certo que a equipe de auditoria analisou cerca de $12 \%$ do total de 429 processos existentes passíveis de gerar a compensação ambiental, de acordo com levantamento realizado pelo Ibama em 2011, conforme tabela ${ }^{167}$ a seguir:

Tabela 1 - $\mathbf{N}^{0}$ Processos analis ados e valores

\begin{tabular}{|l|c|c|c|}
\cline { 2 - 4 } & $\begin{array}{c}\mathbf{N}^{\circ} \text { processos } \\
\text { analisados }\end{array}$ & VR & CA \\
\hline ICMBio & 29 & $\mathrm{R} \$ 20.317 .172 .114,35$ & $\mathrm{R} \$ 109.582 .626,24$ \\
\hline Ibama & 23 & $\mathrm{R} \$ 61.114 .233 .398,90$ & $\mathrm{R} \$ 305.255 .586,82$ \\
\hline TOTAIS & 52 & $\mathrm{R} \$ 81.431 .405 .513,25$ & $\mathrm{R} \$ 414.838 .213,06$ \\
\hline
\end{tabular}

Fonte: processos analisados. Quadro elaborado pela equipe

Primeiramente, merecem atenção os procedimentos e modalidades de execução da compensação ambiental analisados pela auditoria. ${ }^{168} \mathrm{~A}$ aplicação dos recursos inicia-se após a homologação pelo CCAF da

\footnotetext{
${ }^{165}$ Ibid, p.3.

${ }^{166}$ Ibid. p. 3-4.

${ }^{167}$ Ibid. p.4.

${ }^{168}$ Ibid. p. 10.
} 
destinação da compensação ambiental em caráter definitivo, quando são especificadas as ações em que serão empregados os recursos da mesma em cada unidade de conservação beneficiária. Posteriormente, os órgãos gestores estabelecem as ações a serem financiadas com os recursos da compensação ambiental, seu valores e o cronograma de desembolso. Este documento é necessário para o termo de compromisso que deverá ser firmado entre os empreendedores e os órgãos ambientais gestores responsáveis pela unidade de conservação beneficiária, podendo ser federal, estadual e/ou municipal.

Houve uma importante mudança nos últimos anos no que se refere às unidades de conservação federais. Até agosto de 2007, o Ibama acumulava as atribuições de órgão licenciador e gestor das unidades de conservação federais, sendo responsável por todas as etapas da compensação ambiental.

Entre os anos 2000 e 2007, a mesma era executada somente de forma direta, ou seja, os empreendedores realizavam as ações eles próprios ou com a ajuda de terceiros mediante orientações do Ibama. Todavia, tal modalidade se mostrou ineficaz. Os empreendedores não tinham o conhecimento necessário da área ambiental e a necessidade de contratação de recursos para o desempenho de tais atribuições gerava custos indiretos relevantes desviando o foco de suas atividades-fim. Para as unidades de conversação esta modalidade também era prejudicial devido à aquisição de produtos de qualidade baixa e pela morosidade no cumprimento da compensação ambiental pelos empreendedores. A vantagem, contudo, constava no fato de que havia menor burocracia na gestão destes recursos e maior segurança jurídica no entendimento de que o art. 36 da Lei do SNUC consistia em obrigação de fazer, devendo, portanto, ser executada diretamente pelo empreendedor.

Visando dirimir estes problemas, o Ibama contratou a Caixa Econômica Federal para realizar a gestão financeira dos recursos da compensação ambiental, instituindo o Fundo de Investimento de Compensações Ambientais (FICA), fundo este utilizado exclusivamente 
para o gerenciamento dos recursos da compensação ambiental devidos pelos empreendedores, que figuravam como cotistas. Eram firmados termos de compromisso, permitindo que o Ibama movimentasse os recursos depositados, criando então a modalidade de execução indireta. Neste momento, os empreendedores podiam optar pela modalidade direta ou indireta.

O FICA, contudo, também foi alvo de críticas, já que os empreendedores não recebiam quitação das obrigações após o depósito, muitos não concordavam em conceder mandato a um ente público para movimentar recursos em seu nome e pela cobrança de tributos em virtude dos ganhos decorrentes das aplicações que eram contabilizados como lucro em seus balanços, entre outros.

Em agosto de 2007, foi criado o ICMBio, que passou a ser o órgão gestor das unidades de conservação federais, tendo o Ibama continuado com a responsabilidade pelo licenciamento federal. Devido a todos os questionamentos em relação ao FICA, decidiu-se por sua extinção, e o ICMBio firmou com a Caixa o Contrato de Prestação de Serviços 71/2008, para que os recursos da compensação ambiental fossem gerenciados por meio de contas estruturais. Houve a migração do saldo integral dos recursos depositados no FICA para as contas escriturais abertas. Ressalte-se que não houve qualquer aplicação dos recursos depositados no FICA. ${ }^{169}$

Assim, o ICMBio passou a firmar os termos de compromisso com os empreendedores. Uma vez comprovado o depósito dos recursos, por opção do empreendedor, a autarquia emite uma certidão de cumprimento da compensação ambiental relativa às obrigações firmadas no termo de compromisso. A partir desse momento, as decisões sobre aplicação dos recursos são assumidas inteiramente pelo ICMBio, sem ingerência do empreendedor. Esta solução se revelou solução amplamente adotada pelos

\footnotetext{
${ }^{169}$ Segundo consta no relatório de Auditoria, quando este fundo foi extinto, em julho de 2009, o mesmo contava com disponibilidade de $\mathrm{R} \$ 42.122 .463,02$, de recursos que não tinham sido executados, e rendas a receber de R \$272.499,75. (Acórdão 1853/2013-TCU-Plenário, Op. Cit., p. 8).
} 
empreendedores devido às suas vantagens, tais como: maior agilidade na captação dos recursos e procedimentos; maior conhecimento por parte do ICMBio das necessidades das unidades de conservação; disponibilidade imediata dos recursos; maior eficiência dos gastos com os recursos da compensação ambiental, entre outros.

Atualmente, o ICMBio tem 313 unidades de conservação federais sob sua gestão, espalhadas em todos os biomas brasileiros: Amazônia, caatinga, cerrado, mata atlântica, pampa pantanal e marinho. ${ }^{170}$

No que tange os resultados da referida auditoria, destacam-se algumas conclusões principais.

Em relação às deficiências no cálculo da compensação ambiental, foram apresentadas as seguintes deficiências: (i) interrupção da valoração e destinação da compensação ambiental entre 2006 e 2011, em função da indefinição quanto à competência e procedimentos orientadores; (ii) não utilização, de forma sistematizada e prevista em normativos, de critérios de validação do valor de referência (VR) do empreendimento; (iii) inexistência de critérios específicos para o cálculo do grau de impacto considerando as distintas tipologias de empreendimentos, objeto do licenciamento ambiental federal e (iv) pequena amplitude do grau de impacto, que varia de 0 a $0,5 \%$, em função do teto estabelecido pelo Decreto 6.848/2009. ${ }^{171}$ Estes dois últimos fatores não permitem que haja uma diferenciação relevante entre empreendimentos que causam impactos distintos ao meio ambiente a depender da forma de sua implementação. ${ }^{172}$

Sobre o primeiro ponto, ou seja, em relação à interrupção da valoração e destinação da compensação ambiental entre 2006 e 2011, foi informado pelo Ibama que o cálculo do grau de impacto não ficou totalmente paralisado durante este período, já que a partir de 2009 foi editada a metodologia do Decreto 6.848/2009. Naquele momento, não havia

\footnotetext{
170 Disponível em: $\quad$ http://www.icmbio.gov.br/portal/biodiversidade/unidades-deconservacao/biomas-brasileiros.html. Acesso em 22.10. 2013.

${ }^{171}$ Acórdão 1853/2013-TCU-Plenário, Op. Cit., p. 16.

${ }^{172}$ Ibid. p. 67.
} 
setor responsável pelas destinações que estivesse apto a receber os dados do órgão licenciador porque embora a Câmara de Compensação tenha sido recriada no âmbito do MMA, a propositura da ADI 3378-6 fez com que fossem paralisadas as atividades concernentes à compensação ambiental. A auditoria apurou que a paralisação dessas atividades foi ocasionada, em grande parte, pelas incertezas e indefinições normativas, derivadas do questionamento da constitucionalidade do art. 36 da Lei do SNUC no STF. $^{173}$

Destaca-se, neste sentido, parte da conclusão mencionada no acórdão:

Conclui-se que as constantes alterações nos normativos ou ausência de procedimentos definidos para a implementação do instituto da CA, criaram uma série de questões pendentes e que se arrastam até o presente exercício. Em alguns dos processos analisados pela equipe de auditoria, observou-se que a compensação ambiental gerada pelos empreendimentos embora fixada, calculada e destinada, ainda não havia sido efetivamente arrecadada, em flagrante prejuízo às unidades de conservação que seriam potenciais beneficiárias desses recursos destinados à época. Da mesma forma, tal situação contribui para que não se alcance o espírito para o qual a CA foi criada, ou seja, compensar a biodiversidade e demais recursos naturais degradados, em decorrência da implantação de empreendimento de significativo impacto ambiental. Em alguns casos, inclusive, os empreendimentos obtiveram LO e já estão operando. ${ }^{174}$

Verificou-se também que houve uma evolução no procedimento de destinação de recursos da compensação ambiental, como, por exemplo, no estabelecimento de critérios mais específicos, a partir do disposto na Lei do SNUC e nos Decretos 4.340/2002 e 4.868/2009. Ademais, observou-se a criação do CCAF e da formação de equipe de apoio na estrutura da DILIC que proporcionou uma alavancagem da compensação ambiental, que se encontrava descontinuada em virtude da ausência de procedimentos e sucessivas alterações nas normas. Por fim, percebeu-se uma maior qualidade e agilidade à destinação dos recursos, sendo a maior parte deles

\footnotetext{
${ }^{173}$ Ibid. p. 77.

${ }^{174}$ Ibid. p. 24.
} 
destinada às ações de regularização fundiária $(46,8 \%)$, o que demonstra o atendimento ao Decreto 4.340/2002. ${ }^{175}$

Foram encontrados os seguintes entraves no cumprimento da obrigação da compensação ambiental, fazendo com que as demandas das unidades de conservação não fossem atendidas conforme esperado: (i) existência de passivo de processos de licenciamento ambiental de empreendimentos com significativo impacto ao meio ambiente, capazes de gerar compensação ambiental, que ainda não tiveram a compensação ambiental valorada e/ou destinada; (ii) morosidade nos procedimentos adotados entre a destinação da compensação ambiental e a celebração dos termos de compromisso; (iii) questionamentos e impetração de recursos administrativos por parte de empreendedores e judicializações pelo Ministério Público, arguindo, por exemplo, o cálculo, a destinação ou a atualização monetária da compensação ambiental; e (iv) não pagamento de compensação ambiental por parte de empreendedores, em especial algumas entidades públicas. ${ }^{176}$

Sobre este aspecto, foram identificados no Ibama, a partir de grupo de trabalho constituído em abril de 2011, um total de 429 processos passíveis de gerar a compensação ambiental, sendo que em apenas 82 destes processos foram realizados os cálculos devidos relativos à compensação ambiental. Em alguns destes, os recursos já tinham sido executados, restando, assim, 347 processos sem cálculo. Contudo, o próprio Ibama não atribui confiabilidade a essa apuração, alegando que foi realizada por estagiários com pouca familiaridade na temática. ${ }^{177}$

Foram constatadas ainda impropriedades na forma de recolhimento dos recursos da compensação ambiental atualmente adotadas pelo ICMBio, que infringe dispositivos legais e regulamentares e estão em desacordo com julgamentos do TCU em matérias parecidas. ${ }^{178}$ Isto porque a auditoria

\footnotetext{
${ }^{175}$ Ibid. p. 28-29.

${ }^{176}$ Ibid. p. 29

${ }^{177}$ Ibid. p. 79

${ }^{178}$ Alguns dos dispositivos apontados foram os seguintes dispositivos da Lei 4.320/1964:

Art. $3^{\circ}$ A Lei de Orçamentos compreenderá todas as receitas, inclusive as de operações de crédito
} 
verificou que a mesma está ocorrendo de forma indireta, ou seja, através de depósitos dos recursos da compensação ambiental em contras escriturais na Caixa para sua posterior aplicação na unidade de conservação pelo ICMBio, sem a inclusão desses recursos no Orçamento Geral da União (OGU), nem recolhimento via conta única do Tesouro Nacional. ${ }^{179}$ Isto representa um prejuízo da transparência que deveria ser assegurada nas fases de elaboração e discussão dos planos e orçamentos no âmbito da administração pública. ${ }^{180}$

Este modelo de compensação indireta, traz ainda outra consequência danosa, qual seja: a impossibilidade do CCAF de expedir atestado de pleno cumprimento da obrigação para os empreendimentos após o depósito efetuado. Isto traz à tona uma situação anômala, na qual o empreendedor deposita o valor da compensação ambiental em conta escritural da Caixa, aparentemente cumprindo sua obrigação, mas a mesma só é considerada cumprida para fins de licenciamento ambiental, quando os gestores públicos responsáveis por sua aplicação comprovam sua boa e regular aplicação na respectiva unidade de conservação. Ou seja, o cumprimento da obrigação do empreendedor passa a depender de gestores públicos, sobre os quais ele não exerce qualquer poder de direção. ${ }^{181}$

Outro achado da auditoria foi a inadequação da contabilização dos recursos da compensação ambiental, conforme a análise exposta abaixo:

Na fase de execução da auditoria constatou-se que os registros contábeis dos recursos da CA nas rubricas de compensação do ICMBio junto ao Siafi são feitos de forma inadequada, visto que os lançamentos diários informam como histórico 'ajustes' feitos com base em planilhas produzidas pela Caixa. Como consequência, o balancete daquele Instituto não permite uma visualização dos

autorizadas em lei.

(...)

Art. $6^{\circ}$ Todas as receitas e despesas constarão da Lei de Orçamento pelos seus totais, vedadas quaisquer deduções.

(...)

Art. 93. Todas as operações de que resultem débitos e créditos de natureza financeira, não compreendidas na execução orçamentária, serão também objeto de registro, individuação e controle contábil.

${ }^{179}$ Acórdão 1853/2013-TCU-Plenário, Op. Cit., p. 67.

${ }^{180}$ Ibid. p. 46.

${ }^{181}$ Ibid. p. 88. 
valores depositados, dos rendimentos financeiros auferidos e das aplicações da $\mathrm{CA}$, a menos que sejam pesquisados e analisados todos os dias úteis do período examinado. Outra impropriedade refere-se à existência de várias notas de lançamento como estorno.

Além destas ocorrências, verificou-se também que as aquisições de bens móveis e imóveis com recursos da CA não são registrados na contabilidade do ICMBio junto ao Siafi, uma vez que o mecanismos de contas escriturais controladas pela Caixa não sensibiliza as contas contábeis daquele sistema, configurando infringência aos normativos vigentes, em especial a Lei 4.320/1964 e a Lei Complementar 101/2000. ${ }^{182}$

Ademais, foi constatada precariedade nas ações de controle da compensação ambiental atualmente existentes no âmbito do Ibama e do ICMBio, que apresentaram a seguintes deficiências: (i) inexistência de sistema informatizado de controle da compensação ambiental que contenha as seguintes informações, entre outras: quantitativo de processos, status, VR, GU, valor da compensação ambiental, unidade de conservação beneficiária, data de celebração do termo de compromisso; (ii) inexistência de processo sistematizado de prestação de contas dos recursos de compensação ambiental provenientes do licenciamento ambiental federal, estadual e municipal; e (iii) inexistência de ações de fiscalização e monitoramento instituídas pelo Ibama ou pelo MMA sobre a aplicação dos recursos da compensação ambiental federal, com o intuito de verificar a regularidade das contratações e aquisições realizadas pelos órgãos gestores federal, estadual e municipal. ${ }^{183}$

Por fim, mas de forma não menos importante, foi verificada a eficiência, eficácia e efetividade dos gastos pelo ICMBio com recursos da compensação ambiental nas unidades de conservação federais visitadas pela equipe de auditoria, a seguir elencadas: Parque Nacional de Brasília/DF, Parque Nacional Serra do Caparaó/MG, Parque Nacional Serra dos Órgãos/RJ, Reserva Biológica União/RJ, Estação Ecológica Tupinambás/SP e Parque Nacional Sete Cidades/PI.

Em tais unidades, foram observados os resultados dos serviços contratados e os bens adquiridos com os recursos provenientes da

\footnotetext{
182 Ibid. p. 47.

${ }^{183}$ Ibid. p. 51.
} 
compensação ambiental, que estavam em conformidade com o plano de trabalho constante do termo de compromisso firmado. Estes serviços e bens têm contribuído para a missão das unidades de conservação de conservar a biodiversidade e demais recursos naturais. ${ }^{184}$ Além disso, foi constatado que a efetividade dos gastos financiados pela compensação ambiental também tem como causa a eficiência no processo de destinação destes recursos para as unidades de conservação a partir da criação do CCAF.

Ainda sobre este aspecto foi evidenciado o nexo causal entre os serviços contratados e/ou bens adquiridos e a melhoria da capacidade operacional das unidades de conservação, como no exemplo descrito abaixo:

Parque Nacional de Brasília foi implementada sinalização da área da unidade, facilitando a visitação da área pela população e promovendo ação de educação ambiental; também com os recursos da $\mathrm{CA}$ foi adquirido sistema de rádio, possibilitando a comunicação entre os fiscais do parque e a sede durante suas ações de fiscalização, com vistas a reportar incidentes detectados na área do parque, como pessoas perdidas e/ou feridas, focos de incêndio, invasões e desmatamento, e facilitando a coordenação e o monitoramento das ações para combater os problemas. ${ }^{185}$

Por todo o exposto, ao final concluiu-se que:

O instrumento da CA, por ser relativamente recente e por conta de todas as falhas e impropriedades relatadas, ainda não está totalmente implementado, a maturidade demanda tempo. O volume de recursos de CA também aumentará, considerando-se projetos relacionados ao pré-sal e outros empreendimentos constantes da carteira de obras acenadas pelo Governo Federal, que integram a política de aceleração do crescimento do País. A combinação desses fatores exige que os órgãos gestores estejam capacitados operacionalmente para aplicar os recursos da compensação ambiental. Além disso, os órgãos também devem possuir maior controle, consubstanciados em sistemas informatizados e rotinas de fiscalização da aplicação desses recursos.

Tendo em vista as constatações realizadas, conclui-se que há falhas e impropriedades na execução do instituto da compensação ambiental, não obstante o zelo e o comprometimento com que a reduzida equipe diretamente ligada à CA, tanto no Ibama (sete servidores), quanto no ICMBio (14 funcionários), conduzem todas as etapas dos procedimentos. ${ }^{186}$

Assim, apesar da eficiência, eficácia e efetividade verificada pela

\footnotetext{
${ }^{184}$ Ibid. p. 58 .

185 Ibid. p. 61.

${ }^{186}$ Ibid. p. 67-68.
} 
auditoria dos gastos pelo ICMBio dos recursos advindos da compensação ambiental, restou claro como as inúmeras alterações na normatização deste instituto, bem como o ajuizamento da ADI 3378, dentre outros fatores como a precariedade nas ações de controle, incluindo a fiscalização e monitoramento, e a morosidade na valoração e destinação destes recursos têm comprometido a efetiva e justa aplicação da compensação ambiental nas unidades de conservação.

\subsubsection{Esfera estadual}

\subsubsection{Principais polêmicas estaduais}

Em âmbito estadual também foram verificadas polêmicas relativas à compensação ambiental.

Inicialmente, deve ser considerado que não há uma unanimidade nos Estados-membros da Federação quanto à base de cálculo da compensação ambiental, já que alguns observam partes da decisão do STF ou do Decreto Federal 6.848/2009, enquanto outros seguem a redação original do art. 36 da Lei do SNUC.

No Estado do Rio de Janeiro, não há posicionamento definido do órgão ambiental estadual sobre o montante da compensação ambiental a ser aplicada, sendo determinado caso a caso, havendo apenas a Deliberação CECA $4.888 / 2007^{187}$, que segue a regra do $0,5 \%$ como piso, mas estipula um teto de $1,1 \%$.

\footnotetext{
187 Deliberação CECA 4.888/2007, art. $3^{\circ}$ : O percentual a ser aplicado sobre os custos totais previstos para implantação de empreendimentos de significativo impacto ambiental, para fins de compensação ambiental (Lei no 9.985/2000), será obtido pelo produto do Grau de Impacto, do Percentual Máximo para Compensação Ambiental e do Fator de Vulnerabilidade do Bioma Mata Atlântica no Estado do Rio de Janeiro, conforme definição nos termos do art. 2o da Lei da Mata Atlântica (Lei 11.428/2006), de acordo com a fórmula a seguir:

(...)

$\S 5^{\circ}$ - O Percentual Máximo para Compensação Ambiental será de 1,1\% (um vírgula um por cento).

$\S 6^{\circ}$ - Nos casos em que o percentual calculado, obtido através do disposto no caput, for inferior a $0,5 \%$ (zero vírgula cinco por cento), será considerado o percentual de $0,5 \%$ (zero vírgula cinco por cento).

$\S 7^{\circ}$ - Nos casos em que o percentual calculado, obtido através do disposto no caput, for superior a $1,1 \%$ (um vírgula um por cento), será considerado o percentual de $1,1 \%$ (um vírgula um por cento).
} 
Recentemente, no entanto, em $1^{\circ}$ de novembro do presente ano, foi publicada a Lei 6.572/2013, que dispõe sobre a compensação devida pelo empreendedor responsável por atividade de significativo impacto ambiental no Estado do Rio de Janeiro e institui a contribuição por serviços ecossistêmicos nos termos da Lei Federal 9.985/2000.

Segundo a referida lei, o montante de recursos a ser destinado pelo empreendedor, bem como a forma de execução, será fixado pelo órgão licenciador de acordo com o grau de impacto ambiental causado pelo empreendimento. ${ }^{188}$ Deixou-se para o Conselho Estadual de Meio Ambiente (CONEMA) aprovar metodologia para o cálculo da compensação ${ }^{189}$, restando estabelecido que não serão incluídos neste cálculo os investimentos em planos, projetos e programas exigidos no procedimento de licenciamento para mitigação de impactos, bem como os encargos e custos incidentes sobre o financiamento do empreendimento, incluindo as garantias e custos com apólices e prêmios de seguros pessoais e reais. ${ }^{190}$

O Estado do Paraná, por sua vez, definiu, por meio da Resolução Conjunta SEMA/IAP 001/2010, metodologia de cálculo do percentual de compensação ambiental com base nos custos do empreendimento, em contrariedade ao entendimento do STF.

Já o Estado de Minas Gerais optou por adotar a legislação federal no que diz respeito à compensação ambiental, tendo editado o Decreto 45.175/2009 mediante o qual estabeleceu: (i) o valor da compensação calculado a partir do grau de impacto ambiental; (ii) a dedução dos investimentos que possibilitem alcançar níveis de qualidade que superem as exigências estabelecidas pela legislação; e (iii) o percentual de $0,5 \%$ como valor máximo. No entanto, no que tange este último ponto, o referido Decreto não observou a decisão do STF, que determinou que não houvesse fixação de limite percentual para a compensação como visto.

\footnotetext{
${ }^{188}$ Art. $1^{\mathrm{o}}, \S 1^{\mathrm{o}}$ da Lei Estadual 6.572/2013 - RJ.

${ }^{189}$ Art. $1^{\circ}, \S 3^{\circ}$ da Lei Estadual 6.572/2013 - RJ.

${ }^{190}$ Art. $1^{\mathrm{o}}, \S 2^{\mathrm{o}}$ da Lei Estadual 6.572/2013 - RJ.
} 
Situação semelhante ocorreu com o Estado do Espírito Santo, que editou a Resolução CONSEMA 2/2010, que também observou o teto de 0,5\% como Decreto Federal, mas não a determinação do STF ao estabelecer tal percentual.

Já o Estado de Santa Catarina continuou estabelecendo a compensação no percentual mínimo de $0,5 \%$ dos custos totais da implantação do empreendimento, por meio da Portaria FATMA 02/2010.

Por outro lado, também vem sendo observada a edição de inúmeras normas estaduais tratando do tema em descompasso com as normas federais e criando novas regras acerca deste instituto. É justamente para este ponto que chama atenção Édis Milaré, ${ }^{191}$ baseando-se na tese de doutorado de Priscila Santos Artigas, na nova edição de sua obra.

Como explica o referido autor, é importante lembrar, primeiramente, que as disposições do Decreto 6.848/2009, por se tratar de ato normativo federal, devem ser aplicadas em todo o país, tendo em vista a competência legislativa concorrente dos Estados-membros (art. 24, I, VI, VIII, da CRFB/1988). Sendo assim, há uma primazia da União, que edita normas de caráter geral sobre essas matérias e o Estados-membros, em sua competência suplementar, devem apenas "preencher os vazios da lei federal, a fỉm de afeiçoá-la às peculiaridades locais". Tal ressalva é importante, pois segundo relatos de Priscila Santos Artigas, tem se evidenciado que:

Por todo o lado proliferam a edição de normas estaduais para impor medidas compensatórias a incidir no processo de licenciamento ambiental. Não deixa de chamar a atenção a subjetividade das regras e, com isso, transparece o intuito meramente arrecadatório das obrigações, absolutamente desvinculado da intenção de proteção ambiental. ${ }^{192}$

\footnotetext{
${ }^{191}$ MILARÉ, Édis. Op. Cit., p. 1242.

192 ARTIGAS, Priscila Santos. Contribuição ao estudo das medidas compensatórias em Direito Ambiental. Tese de Doutorado. Universidade de São Paulo - USP, 2012, p. 282. Apud. MILARÉ, Édis. Op. Cit., p. 1242.
} 
Assim, segundo Édis Milaré ${ }^{193}$, percebem-se inconstitucionalidades em certas normas estaduais, que acabaram por criar novas regras de compensação ambiental. Seriam inconstitucionais, pois tendo a União estabelecido previamente a regra geral, os Estados não poderiam sair deste escopo normativo e ampliar o que disse a lei federal. Desta forma, os Estados-membros estariam sujeitos a norma federal, podendo apenas legislar dentro de seus limites e de forma mais restritiva. ${ }^{194}$

Como exemplo de Estados-membros que atuaram em desconformidade com a norma federal tem-se o Estado do Mato Grosso do Sul, que contempla duas formas de medidas compensatórias: a primeira delas incidindo sobre empreendimentos que possam causar significativo impacto ambiental e a segunda, aplicando-se a todos os demais empreendimentos que possam causar qualquer tipo de impacto ambiental, sem ser necessariamente significativo. Veja-se, abaixo, dispositivos que elucidam o exemplo tratado aqui retirados da Lei Estadual 3.709/2009:

Art. $1^{\circ}$ Nos casos em que durante o licenciamento ambiental sejam identificados impactos ambientais negativos não mitigáveis, estes deverão ser, obrigatoriamente, objeto de compensação pelo empreendedor de acordo com metodologia para gradação de impacto a ser definida em regulamento.

\footnotetext{
${ }^{193}$ MILARÉ, Édis. Op. Cit., p. 1243.

${ }^{194}$ Ressalte-se, contudo, que há quem entenda em sentido diverso, como, por exemplo, Paulo Bessa Antunes, segundo o qual: "Do ponto de vista puramente ambiental, nem sempre a intervenção mais suave sobre o meio ambiente é a melhor ou a mais necessária. Muitas vezes, em função de intervenções muito pequenas sobre o meio ambiente, surgem situações de profundo desequilíbrio ambiental. Não há qualquer base legal ou constitucional para que se aplique a norma mais restritiva. A ordem jurídica, como se sabe organiza-se em uma escala hierárquica, encimada pela Constituição Federal, que dentre outras coisas, dispõe sobre a competência dos diversos organismos políticos e administrativos que formam o Estado. Pouco importa que uma lei seja mais restritiva e, apenas para argumentar, seja mais benéfica para o meio ambiente, se o ente político que a produziu não é dotado de competência para produzi-la. A questão central que deve ser enfrentada é a que se refere à competência legal do órgão que elaborou a norma. Naturalmente, espera-se que os diferentes entes políticos produzam boas leis, na esfera de suas competências (...). A restrição que o Estado está autorizado legitimamente a opor a uma atividade submetida à competência concorrente não pode ir ao ponto de descaracterizar as normas federais. Trocando em miúdos, um Estado não pode, por exemplo, proibir em seu território um produto que esteja autorizado pela União, ainda que sob o pretexto de estar exercendo a sua competência concorrente em matéria de proteção ao meio ambiente. (ANTUNES, Paulo de Bessa. Direito Ambiental. $15^{\text {a }}$ Edição. São Paulo: Atlas, 2013. p. 172-173).
} 
$(\ldots)$

$\S 3^{\circ}$ As compensações, com fundamento em Estudo de Impacto Ambiental e Relatório de Impacto Ambiental - EIA/RIMA, serão destinadas integralmente, a apoiar a implantação e a manutenção de unidades de conservação do grupo de proteção integral.

$\S 4^{\circ}$ As compensações, com fundamento em outros estudos ambientais que não o EIA/RIMA, serão destinadas ao custeio de atividades de gestão ambiental a cargo do órgão licenciador. (grifos meus)

Vê-se, assim, que especificamente neste Estado-membro a compensação poderá ser derivada do EIA/RIMA, ou seja, de atividades que possam gerar impacto negativo significativo e, nestes casos, os recursos serão atribuídos integralmente às unidades de conservação, mas poderá também ser derivada de outros estudos, caso em que será destinada à atividades de gestão ambiental, tais como: "a aquisição de bens, a execução de obras e serviços, os dispêndios com pessoal e outras exigências pertinentes à execução da política ambiental no âmbito do Estado de Mato Grosso do Sul". 195

Um segundo ponto controvertido acerca da compensação ambiental em âmbito estadual é referente a chamada compensação ambiental social. Verifica-se uma crescente exigência nos licenciamentos ambientais realizados por alguns Estados brasileiros de impor aos empreendedores medidas compensatórias de natureza socioambiental, em razão da verificação de impactos do empreendimento na infraestrutura urbana da região.

É o que ocorre atualmente, por exemplo, no Estado do Rio de Janeiro, que têm exigido a chamada compensação socioambiental. Esta consiste na imposição de medidas compensatórias pelo empreendedor, em geral consubstanciadas em investimentos na infraestrutura pública, como contrapartida do licenciamento ambiental de seus projetos. ${ }^{196}$

A questão principal acerca desta modalidade de cobrança reside no fato de que não há previsão legal para a compensação social como requisito

\footnotetext{
${ }^{195}$ Art. $8^{\circ}, \S 1^{\circ}$ do Decreto Estadual 12.909/2009 - MS.

${ }^{196}$ Disponível em: http://oglobo.globo.com/blogs/blogverde/posts/2011/05/19/em-lisboa-minc-dizque-brasil-esta-de-portas-abertas-investimentos-381383.asp. Acesso em 27.10.2013.
} 
no processo de licenciamento, como há no caso da compensação ambiental.

Neste sentido, vale mencionar que a PNMA, mesmo tendo previsto conceito amplo de poluidor ${ }^{197}$, não previu expressamente o que pode ser definido como impacto ambiental. Entretanto, a Resolução CONAMA 01/1986, em seu art. $1^{\circ}$ esclareceu que impacto ambiental é:

(...) qualquer alteração das propriedades físicas, químicas e biológicas do meio ambiente, causada por qualquer forma de matéria ou energia resultante das atividades humanas que, direta ou indiretamente, afetam: I - a saúde, a segurança e o bem-estar da população; II - as atividades sociais e econômicas; III - a biota; IV - as condições estéticas e sanitárias do meio ambiente; V - a qualidade dos recursos ambientais." (grifos meus)

Assim, seria possível que o órgão ambiental exigisse do empreendedor medidas compensatórias sociais quando este venha a causar impactos no meio social da região onde será instalada sua atividade a despeito da inexistência de regulamentação específica. Segundo Erika Bechara, ${ }^{198}$ as compensações sociais, caso necessárias, são devidas independentemente do pagamento da compensação ambiental, posto possuírem objetivos distintos, como se verifica a seguir:

(...) Devemos esclarecer que a vedação de cobrança simultânea da compensação ambiental antecipada e medidas compensatórias se aplica apenas quando ambas se referirem ao mesmo dano ambiental.

É sabido que a compensação ambiental regrada pelo art. 36 da Lei 9.985/2000 diz respeito apenas aos danos inevitáveis causados ao meio ambiente, não a todo e qualquer bem jurídico. Consequentemente, os impactos sociais e econômicos do empreendimento, conquanto devam ser contemplados nos estudos ambientais e também levados em conta pelo órgão licenciador na análise do projeto, não serão compensados antecipadamente na forma prescrita pela Lei do SNUC.

Por isso, os impactos sociais e econômicos, negativos e inafastáveis, poderão ser compensados previamente por meio de medidas compensatórias específicas - não mais de cunho ambiental, mas de cunho econômico e social - inclusive ao lado e sem prejuízo da compensação ambiental ex ante.

\footnotetext{
${ }^{197}$ Lei $6.938 / 1981$, art $3^{\circ}$ - Para os fins previstos nesta Lei, entende-se por:

(...)

III - poluição, a degradação da qualidade ambiental resultante de atividades que direta ou indiretamente:

a) prejudiquem a saúde, a segurança e o bem-estar da população;

b) criem condições adversas às atividades sociais e econômicas;

c) afetem desfavoravelmente a biota;

d) afetem as condições estéticas ou sanitárias do meio ambiente;

e) lancem matérias ou energia em desacordo com os padrões ambientais estabelecidos;

${ }^{198}$ BECHARA, Erika. Op. Cit., p. 241.
} 
Contudo, poderia ser arguida a configuração de bis in idem, quanto ao pagamento da compensação ambiental prevista no art. 36 da Lei do SNUC, que é calculada com base no somatório de todos os impactos, inclusive os impactos socioambientais. Assim, parece certo que para calcular a compensação social, o órgão ambiental deverá desconsiderar os impactos no meio ambiente natural, tais como fauna, flora, água, ar, solo, ambiente marinho, e apreciar somente os impactos no meio social previstos no EIA/RIMA. Da mesma forma, deverá desconsiderar os impactos sociais para calcular a compensação ambiental do art. 36 da Lei do SNUC. Ademais, o órgão ambiental também deverá levar em conta que o empreendedor não pode substituir o Poder Público e assumir a administração e gestão das questões sociais e urbanas que lhe competem, como a organização da infraestrutura, saneamento básico, limpeza urbana, etc. Ou seja, deverá atentar-se sempre para os parâmetros de razoabilidade. ${ }^{199}$

Somente assim ambas as formas de compensação poderão ser cobradas simultaneamente, com base na instalação de um mesmo empreendimento, sem que ocorra bis in idem e sem que seja imposta ao empreendedor encargos excessivos que vão além de sua obrigação.

\subsubsection{O caso do FUNBIO}

O Estado do Rio de Janeiro vive atualmente situação peculiar no que concerne à aplicação dos recursos da compensação ambiental paga pelos empreendedores, situação esta que culminou no recente ajuizamento da Ação Civil Pública que será abordada a seguir.

Em período anterior a 2009, por meio da Secretaria de Estado do Ambiente (SEA), resolveu-se terceirizar os serviços de gestão dos recursos

\footnotetext{
199 “(...) desejamos frisar que o princípio da razoabilidade tem que ser observado pela Administração à medida que sua conduta se apresente dentro dos padrões normais de aceitabilidade. Se atuar fora desses padrões, algum vício estará sem dúvida, contaminando o comportamento estatal". (FILHO, José dos Santos Carvalho. Manual de Direito Administrativo. $22^{\mathrm{a}}$ ed. Rio de Janeiro: Editora Lumen Juris, 2009. p. 37).
} 
advindos da compensação ambiental dos empreendimentos sujeitos ao EIA/RIMA. Para tanto, foi solicitado parecer à Procuradoria-Geral do Estado, o qual foi apresentado em 29 de outubro de 2009, firmado pelo Subprocurador-Geral do Estado, Rodrigo Tostes de Alencar Mascarenhas.

Foi então apresentado o Parecer 04/09-RTAM-PG-2 que concluiu, em síntese que: (i) a compensação ambiental é uma obrigação direcionada à prevenção ou reparação dos danos a serem causados por empreendimentos de significativo impacto ambiental, a ser cumprida por meio de uma ou mais prestações à escolha do órgão licenciador com base no EIA/RIMA, podendo inclusive ser obrigação cumulativa (prestações de fato e de coisas); (ii) os recursos necessários ao cumprimento desta obrigação não são considerados verba pública, facultando-se ao Poder Público admitir que a prestação seja dada em dinheiro, que só passará a ter natureza pública ao ingressar nos cofres públicos na hipótese de ser pago ao estado; (iii) sua execução pode ser feita pelo empreendedor diretamente ou indiretamente por meio de entidade escolhida e contratada pelo mesmo ou, ainda, indiretamente por meio de entidade indicada ou credenciada pelo Poder Público; (iv) independente da forma de execução, os recursos continuam a ser privados, ainda que vocacionados a uma finalidade pública, devendo o Poder Público fiscalizar sua execução e (v) caso a SEA opte por firmar ajustes com entidades sem fins lucrativos para credenciá-las a executar projetos com recursos privados, é juridicamente possível utilizar parte destes recursos para ressarcir os custos operacionais que as entidades do terceiro setor comprovadamente tenham com a execução das medidas compensatórias, o que deverá ser demonstrado por meio de planilhas detalhadas, vedada a adoção de taxas de administração. ${ }^{200}$

Com fulcro no referido parecer, o Estado do Rio de Janeiro, por meio da SEA, celebrou o Convênio 003/09 com a associação civil Fundo Brasileiro para a Biodiversidade (FUNBIO). O objeto deste convênio seria a operação, manutenção e controle do Mecanismo para a Conservação da

${ }^{200}$ Parecer 04/09-RTAM-PG-2, p. 20. 
Biodiversidade do Estado do Rio de Janeiro (FMA), que é um "Instrumento Financeiro de Compensação Ambiental”, ou seja, um mecanismo destinado à aplicação dos recursos da compensação ambiental do art. 36 da Lei do SNUC, em que o empreendedor, após anuência do INEA, deposita os recursos em conta bancária do FUNBIO e este executa os projetos aprovados pela Câmara de Compensação Ambiental (CCA). Em 2010, contudo, o mencionado convênio foi substituído pelo ora vigente, sem número, de igual natureza, entre o FUNBIO e o INEA.

Alegando que os referidos convênios são nulos, por ausência de licitação, assim como dispêndio pelo FUNBIO, sem licitação, de recursos oriundos da obrigação legal do art. 36 da Lei do SNUC, o Ministério Público do Estado do Rio de Janeiro (MPERJ) ajuizou recentemente, em 24 de junho de 2013, Ação Civil Pública em face do Estado do Rio de Janeiro, do INEA e do FUNBIO, com base no Inquérito Civil 28/2013. ${ }^{201}$

Em que pese a questão processual da referida ação não ser objeto do presente trabalho, o ajuizamento da mesma é de extrema relevância, visto que aponta os problemas e possíveis irregularidades na prática desenvolvida pelo INEA, SEA e FUNBIO, e, consequentemente, na eficiência da aplicação dos recursos oriundos da compensação ambiental podendo gerar verdadeiro prejuízo ambiental ao Estado do Rio de Janeiro.

Ressalte-se que esta ACP foi ajuizada na Comarca de São Pedro da Aldeia, tendo como foco principal o Parque Estadual da Costa do Sol (PECS) e as demais unidades de conservação abrangidas pela $2^{\mathrm{a}}$ Promotoria de Justiça de Tutela Coletiva do Núcleo de Araruama (Araruama, Silva Jardim, Iguaba Grande, Saquarema e São Pedro da Aldeia).

O primeiro ponto abordado na inicial é a alegada irregularidade dos convênios firmados entre o Estado, INEA e FUNBIO. Isto porque, primeiramente, a celebração de convênios ou termos de parceria com uma OSCIP, como é classificado o FUNBIO, deveria seguir, segundo o MPERJ,

\footnotetext{
${ }^{201}$ Petição inicial da ACP, p. 4. Disponível em: http://issuu.com/mp_araruama/docs/acp_funbio_2. Acesso em 27.10.2013.
} 
os princípios e procedimentos de licitação, conforme Decreto 7.568/2011, de forma a garantir uma igualdade de oportunidades quanto às OSCIP interessadas e a garantia das melhores condições financeiras e de eficiência para o Poder Público. Como isto não ocorreu na hipótese apresentada, alega-se que seria ilegal a transferência a uma OSCIP, por convênio, da gestão de recursos públicos mediante remuneração variável, sem licitação ou procedimento com as garantias formais e materiais do processo licitatório, que garantem a isonomia e a economicidade. Seria então nulo o convênio firmado, por violar as regras da Lei 8.666/1993 e do Decreto $6.170 / 2007 .^{202}$

Ademais, foi permitido ao FUNBIO, por força dos convênios, ${ }^{203}$ descontar os valores relativos a uma suposta "recuperação de custos" do valor da compensação por ele recebido. Segundo o MPERJ, isto é uma remuneração pelos serviços prestados de gerenciamento dos recursos da compensação ambiental, como uma espécie de comissão de gerência. Isto é vedado pela Lei Estadual 5.501/2009 ${ }^{204}$, que estabelece o regime das OSCIP, pois havendo esses elementos no convênio, estar-se-ia, na realidade, diante de um contrato. ${ }^{205}$ Veja-se, abaixo, a explanação do MPERJ:

Em outras palavras, a ONG FUNBIO opera como uma consultoria privada que, embora não distribua lucros, aufere rendimentos pelos serviços prestados como um particular ou empresa com fins lucrativos, que cobra seus serviços por horas de trabalho. Isso sem falar nos ocultos "custos variáveis" e nos "consultores

\footnotetext{
${ }^{202}$ Ibid. p. 6-8.

${ }^{203}$ Cláusula Quinta:

Parágrafo Primeiro - Os repasses financeiros previstos no Instrumento Financeiro de Compensação Ambiental serão realizados diretamente pelo empreendedor, que se obriga ao pagamento da compensação ambiental, ao FUNBIO, para execução de projetos ou aplicação Instrumento Financeiro Fiduciário, conforme indicado pela SEA.

Parágrafo Segundo - Ao FUNBIO será permitido, semestralmente deduzir dos recursos de compensação ambiental sob sua gestão, os custos relativos à gestão e execução dos mesmos, em conformidade com a planilha de custos demonstrativa anexa a este convênio (ANEXO 2) e, somente após autorização expressa da SEA.

${ }^{204}$ Lei 5.501/2009, Art. 14: É vedada a inclusão, tolerância ou admissão, nos termos de parceria, sob pena de nulidade do ato e responsabilidade do agente, de cláusulas ou condições que prevejam ou permitam:

I - realização de despesas a título de taxa ou comissão de administração, de gerência ou similar. (...) ${ }^{205}$ Petição inicial da ACP, Op. Cit., p. 8-9.
} 
externos" que o Convênio prevê, sem definir. Por isso, o que é chamado de convênio tem, na verdade, natureza jurídica de contrato, para o qual haveria e há concorrência de mercado (quem não quer prestar serviços de gerenciamento de recursos por $\mathrm{R} \$ 838.741,45$ semestrais?), sendo possível e devida a prévia licitação, que nunca existiu.

Sim, o serviço contratado (a gestão de recursos para a criação e manutenção de unidades de conservação) tem uma aplicação de interesse público, como toda contratação pela Administração. Mas, antes de uma finalidade pública primária e convergente, há o interesse pecuniário da FUNBIO em receber os valores que remuneram seu quadro de empregadores, diretores etc. Basta ver que, não fosse a remuneração paga ao FUNBIO, a chamada "recuperação de custos", o FUNBIO não cumpriria as obrigações que lhe cabem por conta do Convênio. Ou seja, o FUNBIO não celebrou o Convênio por um interesse convergente com o do Estado, mas antes disso, pelo interesse de ser remunerado pelas próprias verbas a ele repassadas para gerenciar. ${ }^{206}$

Afirma o MPERJ, neste sentido, que o FUNBIO teria perdido sua característica de OSCIP e o convênio sua natureza de convênio, e que estarse-ia então diante de um contrato de prestação de serviços, o qual deveria ter prévia licitação e controle de contas pelo Tribunal de Contas do Estado. Contudo, levando em conta o parecer jurídico que deu origem ao Convênio, por ter considerado a verba recebida como privada, não está havendo o controle oficial de contas. ${ }^{207}$

Outro ponto trazido na inicial foi o de que nunca houve fundamento legal para a dispensa de licitação com relação às contratações feitas pelo FUNBIO, para o dispêndio dos recursos recebidos por força do convênio.

Sobre este aspecto, deve ser notado primeiramente que os valores repassados ao FUNBIO pelos empreendedores envolvem cifras milionárias. $^{208}$ Segundo o balanço patrimonial anual ${ }^{209}$ relativo ao ano de 2012, divulgado pelo site do FUNBIO, o mesmo tinha como saldo o valor de $\mathrm{R} \$ 325.705 .000,00$. No que tange o campo das receitas operacionais sob

\footnotetext{
${ }^{206}$ Ibid. p. 11

${ }^{207}$ Ibid. p. 12-13.

${ }^{208}$ Com base no Relatório de Cumprimento do Convênio 003/2009, o MPERJ demonstra que os valores recebido até 30 de setembro de 2012 chegam a $\mathrm{R} \$ 126.897 .475,25$, além do rendimento financeiro de $\mathrm{R} \$ 9.665 .638,39$ relativos às aplicações financeiras daquele valor, enquanto o montante recebido para a manutenção de unidades de conservação foi de $\mathrm{R} \$ 19.099 .464,85$. 209

Disponível

em:

https://docs.google.com/file/d/0B155ih66QdFPM0UtQ0NjUDVZMms/edit?usp=sharing+https://d ocs.google.com/file/d/0B155ih66QdFPd0ZaZ2h6RXNIUWM/edit?usp\%3Dsharing\&pli=1. Acesso em 27.10.2013.
} 
o nome de "reembolso de projetos" o valor chegou a $\mathrm{R} \$ \mathbf{6 . 7 2 9 . 0 0 0 , 0 0 \text { , as }}$ “taxas de administração" a 1.849.000,00 e os "serviços prestados" a R\$ 649.000,00. Do valor auferido, R\$ 202.195.000,00 são aplicações financeiras no país, enquanto R \$ 109.209.000,00 estão aplicados no exterior e apenas do Estado do Rio de Janeiro, até o final do ano de 2012, o FUNBIO recebeu por meio dos termos de compromisso de compensação ambiental a quantia de $\mathrm{R} \$ 229.000 .000,00$.

O exemplo trazido pela inicial da ACP de uma das recentes contratações do FUNBIO diz respeito ao Parque Estadual Costa do Sol, que estaria anunciado na própria página da internet desta ONG a contratação de consultoria para a elaboração do plano de manejo desta unidade de conservação por R $\$ 1.372 .800,00$. Sendo que, para participar do processo de seleção, bastaria enviar manifestação de interesse e "material que demonstre sua qualificação para desempenhar os serviços, comprovação de capacidade técnica, portfólio ou outros documentos que julguem importantes na apresentação de suas empresas". ${ }^{210}$ Ou seja, procedimento relativamente simples e bem diferente do processo licitatório.

$\mathrm{Na}$ prática, o INEA calcula o valor que deve ser pago pelo empreendedor à título de compensação ambiental. Em seguida, é assinado "termo de compromisso de compensação ambiental" entre o INEA e o empreendedor, no qual este se compromete a depositar o valor delimitado em conta bancária do FUNBIO. Posteriormente, o FUNBIO contrata livremente, sem licitação, quem quiser para a execução dos projetos voltados para as unidades de conservação do Estado. O mais estranho, segundo o MPERJ, é o fato de que o próprio FUNBIO, o INEA e a SEA aparecem como responsáveis pela maior parte dos projetos. ${ }^{211}$

Outra estranheza apontada foi a de que na primeira versão do Convênio firmado entre as partes havia a previsão em realizar "licitações", mas a nova versão, assinada em $1^{\circ}$ de abril de 2010, deixou de fazer

\footnotetext{
${ }^{210}$ Petição Inicial da ACP, Op. Cit. p. 14-15.

${ }^{211}$ Ibid. p. 17.
} 
menção a este termo, substituindo-o por um dever genérico de condução de processo seletivo. De qualquer forma, alega o MPERJ, que permanecem ilegais todas as contratações transferidas a este fundo, já que a licitação não permite o uso de "genéricos".

Além disso, a Lei 9.790/1999 212 determina que para a dedicação das atividades nele previstas configura-se mediante a execução direta de projetos ou pela prestação de serviços intermediários de apoio a outras organizações sem fins lucrativos.

No entanto, a execução dos projetos pelo FUNBIO não é direta como exige a lei, nem indireta, pela contratação de outras organizações sem fins lucrativos, mas por empresas, desvirtuando, mais uma vez, a ideia de um convênio celebrado com uma OSCIP, como se vê através da explanação transcrita a seguir:

Tanto a ideia de convênio ou termo de parceria com uma OSCIP foram absolutamente desvirtuadas: o FUNBIO funciona, desde a celebração de seu Convênio, como um instrumento para que as contratações realizadas para a execução dos projetos com recursos da compensação ambiental do art. 36 do LSNUC sejam realizadas com dispensa indevida de licitação. Ao invés do rígido controle procedimental da Lei n. 8.666/93, com o controle externo do Tribunal de Contas e com os deveres/poderes de agentes públicos que conduzem licitações, contratações milionárias, como a do Plano de Manejo do Parque Estadual da Costa do Sol, se dão sem qualquer controle, comunicação de critérios ou publicidade adequada. Basta ver a fragilidade do "processo de licitação" indicado no site do Funbio quanto a plano de manejo do PECS e compará-lo com as diretrizes descritas no art. $3^{\circ}$ da Lei de Licitações e no inciso XXI, do art. 37, da Constituição. O distanciamento é inequívoco. ${ }^{213}$

\footnotetext{
${ }^{212}$ Art. $3^{\circ}$ : A qualificação instituída por esta Lei, observado em qualquer caso, o princípio da universalização dos serviços, no respectivo âmbito de atuação das Organizações, somente será conferida às pessoas jurídicas de direito privado, sem fins lucrativos, cujos objetivos sociais tenham pelo menos uma das seguintes finalidades:

(...)

VI - defesa, preservação e conservação do meio ambiente e promoção do desenvolvimento sustentável;

(...)

Parágrafo único. Para os fins deste artigo, a dedicação às atividades nele previstas configura-se mediante a execução direta de projetos, programas, planos de ações correlatas, por meio da doação de recursos físicos, humanos e financeiros, ou ainda pela prestação de serviços intermediários de apoio a outras organizações sem fins lucrativos e a órgãos do setor público que atuem em áreas afins.

${ }^{213}$ Petição Inicial da ACP, Op. Cit., p. 18.
} 
Por estes motivos, ou seja, justamente pelo FUNBIO ter sido escolhido para gerenciar todos os recursos das compensações ambientais sem a devida licitação e por ele próprio contratar também sem licitação, relata o MPERJ ser inquestionável a ilegalidade das contratações realizadas com a aplicação das verbas da compensação ambiental.

O terceiro e último ponto arguido na inicial é o de que sempre será necessária prévia licitação para a execução dos projetos para atingir as finalidades previstas no art. 36 da Lei do SNUC, independente da discussão acerca da natureza jurídica da verba.

Neste sentido, o mencionado Parecer 04/09-RTAM-PG-2 da PGE concluiu pela natureza privada destes recursos. Os argumentos podem ser resumidos da seguinte forma: (i) apenas faria sentido se falar em "verba pública" se a obrigação em questão for uma obrigação pecuniária, mas, na realidade, serão fixadas pelo órgão licenciador ações ou medidas concretas para evitar ou compensar o impacto do empreendimento e tais medidas serão, em regra, obrigações de fazer, podendo eventualmente ser uma obrigação de dar (não pecuniária); (iii) o objetivo do instituto é a reparação do dano ambiental, portanto a prestação in natura é o meio mais adequado e esta constitui em uma obrigação de fazer; (iv) mesmo se o empreendedor se desincumbir desta obrigação mediante o pagamento de um valor ao ente licenciador, a obrigação continuará sendo de fazer ou, eventualmente, de dar, mas não pecuniáriaa ${ }^{214}$; (iv) seria de extrema dificuldade enquadrar como receita pública um "crédito" incerto como a compensação ambiental (não se sabe quantos pedidos serão protocolados, nem quantos serão deferidos, o montante de cada obrigação, etc); (v) mesmo se for considerada uma obrigação de pagar, não será afastada a necessidade de que os recursos

\footnotetext{
${ }^{214}$ Sobre este ponto, veja-se explanação exposta no parecer: "De todo modo, não se nega que o empreendedor pode preferir cumprir sua obrigação mediante simples pagamento e que - sob a condição acima exposta - o poder público pode concordar com esta opção. Esta possibilidade pode levar à falsa impressão de que a obrigação em questão é, essencialmente, de pagar ao ente licenciador um determinado valor que, então, seria uma verba pública. Também é verdade que a confusão entre a ação de apoiar e o seu custo pode, em parte, ter algum suporte no acórdão do STF que fala na competência do órgão licenciador para "fixar o quantum da compensação" (Parecer 04/09-RTAM-PG-2, p. 13).
} 
recebidos sejam aplicados exclusivamente na finalidade da lei, contudo tal vinculação não seria possível, já que esta receita não está prevista no orçamento para atender a esta despesa, nem configura uma das exceções (vinculações constitucionais ou decorrentes da criação de fundos orçamentários especiais); (vi) não seria possível admitir uma despesa que não está prevista na Lei Orçamentária, mas no curso de um procedimento de licenciamento. ${ }^{215}$

Ademais, o parecer concluiu pela possibilidade de repasse a terceiros que o implementariam, podendo o devedor escolher cumprir a obrigação in natura, contratar terceiro para fazê-lo, ou pagar em dinheiro aos órgãos licenciados, sendo que apenas na última hipótese estar-se-ia diante de verba pública. Por fim, ressaltou:

\begin{abstract}
No entanto, nada impede que o poder público indique ao empreendedor entidades que - a seu juízo - são reconhecidas como aptas a executar a ação em questão, ou que, como parece ter feito à União, indique fundos específicos nos quais o valor correspondente ao custo da medida deva ser depositado. Com efeito, se o particular pode executá-las de forma direta, se pode contratar alguém para executá-las em seu nome, não há nenhuma razão para que não possa contratar tal execução com entidade que seja indicada, mediante certificação, credenciamento ou outro instrumento, pelo poder público. Registre-se que esta forma de execução não nos parece possa ser compulsória. Ou seja, não se pode obrigar o particular a repassar dinheiro para entidade específica (mesmo que reconhecida pelo poder público), para a execução da medida, mas é possível facultar ao empreendedor esta opção. ${ }^{216}$
\end{abstract}

O MPERJ rebateu tais argumentos, arguindo, primeiramente, em contraposição à possibilidade de cumprimento da obrigação in natura, que tal forma de compensação seria inviável enquanto a atividade que lhe deu origem ali perdurar. Primeiro porque uma vez licenciada a instalação de determinada atividade, seria impossível replantar, por exemplo, no mesmo

\footnotetext{
${ }^{215}$ Em suma: "Ainda que a obrigação em questão possa ser cumprida mediante um pagamento, e que este pagamento possa ser feito à administração, isto não torna a obrigação em questão um crédito pecuniário da administração pública. $\mathrm{Na}$ verdade, como já adiantado, a compensação ambiental em questão se constitui em uma obrigação ex lege, direcionada à prevenção ou reparação dos danos a serem causados pelo empreendimento sujeito ao licenciamento, a ser cumprida por meio de uma ou mais prestações à escolha do órgão licenciador, na forma das conclusões decorrentes do procedimento de licenciamento ambiental, em especial de seu EIA/RIMA". (Parecer 04/09-RTAM-PG-2, p. 16).

${ }^{216}$ Parecer 04/09-RTAM-PG-2, p. 18.
} 
local vegetação que foi suprimida em virtude de sua instalação, já que o empreendimento está e continuará justamente naquele exato local. As únicas opções seriam então de pagamento em dinheiro ou de compensação em espécie para criar em outra área os mesmos serviços ambientais suprimidos. A opção do legislador brasileiro, contudo, foi a da compensação ambiental da Lei do SNUC.

Ademais, a Resolução CONAMA 371/2006 utiliza as expressões "desembolso", "gestão de recursos" e "aplicação de recursos" que remetem ao pagamento em dinheiro pelo empreendedor. E é justamente esta a forma pela qual a obrigação da compensação ambiental vem ocorrendo, ao contrário das possibilidades trazidas no parecer da PGE. Tendo em vista a dupla dispensa de licitação alegada pelo MPERJ em relação ao FUNBIO, afirma o mesmo que a única forma legal de cumprimento da obrigação do art. 36 da Lei do SNUC é o pagamento em dinheiro pelo empreendedor ao órgão licenciador da quantia calculada.

Ainda nesta seara argumentativa, o Parecer da PGE tentou fazer crer que na expressão "[o]s órgãos ambientais responsáveis pela gestão dos recursos de compensação", constante da Resolução CONAMA 371/2006, seria possível a ideia de que essa gestão poderia ser uma permissão de contratação direta pelo empreendedor com aqueles recursos. Segundo o MPERJ, contudo, trata-se de distorção de linguagem, uma vez que somente a licitação garante as melhores condições financeiras para a finalidade pública da contratação dos projeto com os recursos da compensação ambiental e a igualdade de condições dos concorrentes, conforme art. 37, XXI da CRFB/1988. Assim, pelo imperativo normativo de máxima efetividade das normas constitucionais, não seria possível concluir, em contrariedade ao parecer, pela dispensa de licitação no caso em tela.

Por todos os fatos e argumentos trazidos na inicial da ACP ajuizada pelo MPERJ e aqui expostos, concluiu-se que: (i) o FUNBIO não pode ser considerado OSCIP porque seu interesse primeiro é a contraprestação pecuniária pelos serviços que presta ao INEA e porque aplica os recursos 
públicos que recebe de forma indireta, pela contratação de empresas com finalidades lucrativas; (ii) os convênios firmados entre o INEA e o FUNBIO são ilegais porque não foram precedidos de processo seletivo com as garantias e princípios da licitação, não possuem natureza de convênio, mas de contrato de prestação de serviços, permitem o ato ilegal de dispensa de licitação dos recursos públicos que recebe ao autorizar o FUNBIO a contratar terceiros para a execução indireta da obrigação; e (iii) todas as contratações realizadas pelo FUNBIO, inclusive a elaboração de plano de manejo do PECS, com o uso dos recursos da compensação ambiental são ilegais porque é indispensável prévia licitação e que tal obrigação é cumprida mediante o pagamento em dinheiro pelo empreendedor ao órgão licenciador e nenhum procedimento seletivo adotado por interposta pessoa ou entidade, como o FUNBIO, substitui a legitimidade e os demais requisitos legais da licitação. ${ }^{217}$

Em 02 de julho de 2013, menos de um mês após o ajuizamento da $\mathrm{ACP}$, o juiz da $2^{\mathrm{a}}$ Vara de São Pedro da Aldeia proferiu decisão ${ }^{218}$ concedendo em parte a tutela antecipada requerida ao considerar que:

Percebo verossimilhança na alegação de que a relação existente entre os Demandados seria de natureza contratual dissimulada sob a forma de convênio, ainda mais quando os mesmos não demonstraram ao Ministério Público a realização das providências contidas no artigo 116 , $\S \S 2^{\circ}, 4^{\circ}$ e $5^{\circ}$, da Lei 8.666/93. Com efeito, diante do que foi trazido pelo Ministério Público, entendo que há densa plausibilidade jurídica no pedido antecipatório, eis que presente a verossimilhança quanto ao desvirtuamento da FUNBIO como Organização da Sociedade Civil de Interesse Público na execução do convênio celebrado com o INEA e o Estado do Rio de Janeiro, bem como indícios de violação ao artigo 37 da CR/88, às Leis Federais $n^{\circ} \mathrm{s}$ 8.666/93, 9.790/99 e 9.985/00, à Lei Estadual $n^{\circ}$ 5501/2009 e ainda à Resolução CONAMA nº 371/2006.

O perigo na demora advém da própria tramitação natural da demanda e, nesse interregno, a FUNBIO continuará executando o convênio, administrando diretamente milhões de reais advindos de repasses de compensações ambientais sem qualquer tipo de controle estatal e sem licitação, sendo inquestionável que irá

\footnotetext{
${ }^{217}$ Petição Inicial da ACP, Op. Cit., p. 25.

${ }^{218}$ Disponível em:

https://docs.google.com/file/d/0B155ih66QdFPUUtMeHI1ZXJ1VUU/edit?usp=sharing\&pli=1. Acesso em 27 de outubro de 2013.
} 
delegar a execução do convênio à sociedades empresárias subcontratadas, sem qualquer tipo de clareza quanto aos processos seletivos empregados, principalmente em relação aos valores pagos, e ainda descontará das compensações ambientais seu 'reembolso' pelos custo da gestão, quadro esse que coloca flagrantemente em risco a preservação ambiental do Parque da Costa do Sol.

\section{A decisão ${ }^{219}$ que deferiu no mérito a antecipação dos efeitos da tutela} pelo referido magistrado foi, contudo, suspensa pela Presidente do TJRJ em sede de Suspensão dos efeitos da liminar (Processo 004006581.2013.8.19.0000) em 22 de julho de 2013 ao considerar que:

A medida implica na suspensão imediata e integral dos projetos e atividades de reparação ambiental em curso naquelas localidades, em especial do Parque

\footnotetext{
${ }^{219}$ Veja-se o teor da decisão: 1) DECLARAR suspensos, no âmbito da competência territorial funcional deste juízo, os efeitos de reconhecimento da FUNBIO como OSCIP, o que faço com fulcro no artigo $7^{\circ}$ da Lei Federal $n^{\circ} 9.790 / 99$ e artigo $9^{\circ}$ da Lei Estadual $n^{\circ} 5.501 / 2009 ; 2$ ) PROIBIR o INEA e o Estado do Rio de Janeiro de repassar, e ao FUNBIO de gerenciar, os recursos provenientes do artigo 36 da Lei Federal $\mathrm{n}^{\circ}$ 9.985/00, advindos de todos os empreendimentos localizados nos Municípios abrangidos pelo Parque Estadual da Costa do Sol (São Pedro da Aldeia, Saquarema, Araruama, Cabo Frio, Arraial do Cabo e Armação de Búzios), ou destinados a qualquer outra unidade de preservação ambiental localizada nos mesmos Municípios. Contudo, ficam o Estado do Rio de Janeiro e o INEA autorizados a contratar, mediante prévia licitação, os serviços e obras descritos no Decreto $\mathrm{n}^{\circ} 4.340$, de 22 de agosto de 2002 , observando-se as prioridades contidas no seu artigo 33, sob pena de multa de $\mathrm{R} \$ 50.000,00$ por cada ato em desacordo com esta decisão, nos moldes do artigo 461 , $\S \S 4^{\circ}$ e $5^{\circ}$, do CPC, sem prejuízo da multa prevista no artigo $14, \mathrm{~V}$, da CPC; 3) DETERMINAR que o Réu FUNBIO deposite junto aos cofres públicos, no prazo de 10 (dez) dias, a contar da intimação, em conta a ser indicada pelo INEA e/ou Estado do Rio de Janeiro, todos os valores que estejam em seu poder, desde o ajuizamento da presente demanda, referentes aos recursos provenientes do artigo 36 da Lei 9.985/00 destinados ao Parque Estadual da Costa do Sol, sob pena de multa diária de R \$ $50.000,00$, nos moldes do artigo $461, \S \S 4^{\circ}$ e $5^{\circ}$, do CPC, sem prejuízo da multa prevista no artigo 14 , V, da CPC, enquanto não houver comprovação do cumprimento da obrigação, e, para tanto, deverá apresentar nos autos demonstrativo contábil dos valores recebidos e prova da transferência bancária; 4) DETERMINAR que os Réus, por meio de seus representantes legais, tragam aos autos, no prazo de 05 (cinco) dias, a contar da intimação, demonstrativo de todos os recursos indicados no item 02 repassados para entidades privadas nos últimos 12 (doze) meses, sob pena de multa diária $\mathrm{R} \$ 20.000,00$, nos moldes do artigo 461 , $\S \S 4^{\circ}$ e $5^{\circ}$, do CPC, sem prejuízo da multa prevista no artigo 14, V, da CPC; 5) DETERMINAR que o Estado do Rio de Janeiro e o INEA se abstenham de promover contratação sem prévia licitação, direta ou indiretamente, ou por meio da FUNBIO, de quaisquer empresas ou entidades privadas para execução das atividades de proteção ao meio ambiente nos Municípios indicados no item 02 ou com recursos da compensação ambiental, sob pena de multa de $\mathrm{R} \$ 100.000,00$ por cada ato praticado em desacordo com esta decisão, nos moldes do artigo 461 , $\S 4^{\circ}$ e $5^{\circ}$, do CPC, sem prejuízo da multa prevista no artigo 14 , $\mathrm{V}$, da CPC; 6) DETERMINAR que o Estado do Rio de Janeiro, o INEA e o FUNBIO submetam ao Tribunal de Contas do Estado, no prazo de 10 (dez) dias, a contar da intimação, o detalhamento de todas as contratações já realizadas pela FUNBIO ou qualquer outra entidade, para a finalidade descrita no artigo 36 da Lei Federal $n^{\circ}$ 9.985/00, nas condições indicas no item 02, desde a assinatura dos respectivos convênios, devendo no prazo em questão juntar aos autos o protocolo junto ao com a relação de documentos entregues àquela Corte, sob pena de multa diária de $\mathrm{R} \$$ $50.000,00$, nos moldes do artigo $461, \S \S 4^{\circ}$ e $5^{\circ}$, do CPC, sem prejuízo da multa prevista no artigo 14 , V, da CPC.
} 
Estadual da Costa do Sol, sem uma alternativa efetiva a curto ou médio prazo, já que a decisão condiciona ainda a realização de tais atividades à realização prévia de procedimentos licitatório, diretamente pelo Estado e o INEA, para a contratação de empresas ou entidades para a execução de atividades de proteção ambiental.

Diante deste quadro, constata-se vulneração ao interesse e à ordem pública o que autoriza, na forma do art. $4^{\circ}$ da Lei 8.437/92, o deferimento da suspensão dos efeitos da liminar concedida pelo juízo de primeiro grau. ${ }^{220}$

De fato, parece sensato o argumento trazido para suspender os efeitos da liminar previamente concedida de que de nada adianta suspender os projetos e atividades do FUNBIO sem uma proposta plausível e eficiente de como gerir os recursos advindos da compensação ambiental. Arguir que o FUNBIO atua duplamente sem licitação e que a forma correta seria seguindo o procedimento licitatório para garantir as melhores condições financeiras na contratação dos projetos, a igualdade de condições entre os concorrentes e um sistema eficiente de gestão dos recursos parece óbvio, mas na prática, qual seria a solução? Suspender suas atividades e contratos celebrados, ou seja, paralisar a gestão e aplicação desses recursos, que como viu-se, é de extrema importância para a manutenção do SNUC e, consequentemente, para proteção da biodiversidade e promoção do meio ambiente ecologicamente equilibrado? A gestão desses recursos seria repassada para o INEA, órgão ambiental que tem outras inúmeras atribuições e obrigações?

Ademais, entre os argumentos apresentados por ambas as partes, a obrigação da compensação ambiental parece de fato consistir em uma obrigação de fazer e não em uma obrigação pecuniária, visto que a obrigação é em sua essência de "apoiar" a implantação ou manutenção de uma unidade de conservação. O empreendedor poderá, se assim entender, pagar o valor correspondente a tal obrigação depositando o mesmo na conta do FUNBIO, contudo ele não está obrigado a proceder desta forma. Assim, entendendo que, neste ponto, assiste razão a PGE. Inclusive porque se for considerada como obrigação de pagar, isto pode levar a ideia equivocada, já \begin{tabular}{l}
$\begin{array}{c}\text { Disponível } \\
220\end{array}$ \\
http://www1.tjrj.jus.br/gedcacheweb/default.aspx?UZIP=1\&GEDID=00046C16ED98A770FBBF0 \\
\hline 46088CF21E1916EC50235174658. Acesso em 27.10.2013.
\end{tabular} 
abordada no presente trabalho, de que a compensação é um direito de pagar para poluir. Parece mais razoável, portanto, considerar que é uma obrigação de fazer que poderá, eventualmente e por opção do empreendedor, se converter em pagamento de determinada quantia.

No entanto, deve ser considerado ainda que independente da verba ser privada ou pública, retirar esta atividade do FUNBIO e repassá-la ao INEA, como pretende o MPERJ, pode acabar trazendo mais prejuízos do que benefícios na aplicação destes recursos. Esta preocupação é inclusive observada no mencionado parecer da PGE, ao relatar que "uma série de inconvenientes inerentes aos custos e despesas do aparato estatal fariam com que houvesse perda de eficiência na aplicação de recursos provenientes da compensação ambiental". ${ }^{221}$ E é este o ponto central que deve-se ter em mente e a pergunta que deve ser formulada pelos magistrados envolvidos neste processo: o que, na prática, será mais benéfico para as unidades de conservação?

Por outro lado, não parece razoável permitir que o FUNBIO continue contratando livremente, como ocorreu no exemplo do Parque Estadual da Costa do Sol, sem haver transparência neste processo e sem que população seja informada de como estas contratações estão ocorrendo e como os recursos vêm sendo aplicados. Mesmo que se permita a continuidade do FUNBIO como órgão gestor da compensação ambiental, pelo receio de que a alteração desta situação possa representar verdadeiro prejuízo ambiental, isto não impede que sua forma de atuação possa ser modificada para atender o interesse maior de proteção ao meio ambiente. Certas alterações podem ser simples e significar relevante melhora, como, por exemplo, um processo mais rigoroso e transparente de contratação de empresas pelo FUNBIO, mesmo que não seja por licitação, e a disponibilização de suas contas para que a população tenha conhecimento de como estão sendo geridas as unidades de conservação e os empreendedores saibam como os recursos dispendidos por eles estão sendo aplicados. Assim, quem quiser

${ }^{221}$ Parecer 04/09-RTAM-PG-2, p. 2. 
(não só os órgãos públicos, mas também os cidadãos e os empreendedores), poderá contestar tais contas administrativa e judicialmente caso verifiquem qualquer irregularidade, mesmo que isto não seja como o controle de contas pelo Tribunal de Contas do Estado pretendido pelo MPERJ.

Outro ponto que não parecer prosperar é a utilização das "taxas de administração" pelo FUNBIO, visto que tanto a PGE como o MPERJ concordam no sentido de sua vedação expressa pela Lei Estadual das OSCIPS, mencionada previamente.

Enfim, esta questão está atualmente nas mãos do judiciário e teremos que aguardar as próximas cenas para verificar qual será a tão esperada solução encontrada.

Por fim, merece destaque, o que a recém publicada Lei 6572/2013 do Estado do Rio de Janeiro, mencionada no item 3.2.2.1, estabeleceu sobre este ponto em específico:

Art. $2^{\mathbf{0}}$ - A critério do empreendedor, a execução das medidas de apoio à implantação e manutenção de unidade de conservação poderá ser feita:

I - diretamente pelo empreendedor; $\square$

II - por pessoa física ou jurídica por ele contratada e de sua responsabilidade.

Art. 3o - O empreendedor poderá alternativamente à execução das medidas de apoio à implantação e manutenção de unidade de conservação do Grupo de Proteção Integral, que trata do artigo 2o, depositar o montante de recurso, fixado pelo órgão estadual competente para o licenciamento, à disposição de mecanismos operacionais e financeiros implementados pela Secretaria de Estado do Ambiente para viabilizar e centralizar a execução conjunta de obrigações de diversos empreendedores, objetivando ganho de escala, de sinergia e de eficiência na proteção do meio ambiente.

\$10 - O depósito integral dos recursos a que se refere o caput deste artigo desonera o empreendedor das obrigações de que trata o artigo 1o desta lei e autoriza a quitação.

\$20 - O mecanismo de que trata o caput poderá ser gerido por entidade conveniada com a Secretaria de Estado do Ambiente, devidamente identificada com os objetivos do projeto a ser executado; com capacidade de cumprir os objetivos específicos do projeto com equipe especializada e obrigatoriedade de publicação anual de síntese do relatório de gestão e do balanço no Diário Oficial do Estado, podendo incluir outros recursos além daqueles destinados à compensação ambiental. 
Art. $7^{\circ}$ - O órgão competente deverá, semestralmente, divulgar em site e no Diário Oficial do Estado do Rio de Janeiro, o balanço dos recursos arrecadados e dos gastos já realizados. (grifos meus).

Assim, vê-se que a referida lei previu, primeiramente, a possibilidade do empreendedor de executar as medidas de apoio às unidades de conservação diretamente ou pela contratação de pessoa física ou jurídica. Além disso, previu também a possibilidade da compensação ambiental ser gerida por uma entidade conveniada com a SEA, como é o caso do FUNBIO, contanto que seja identificada com os objetivos do projeto, tenha capacidade de cumpri-los com equipe especializada e publique anual seu relatório de gestão.

Percebe-se, portanto, que a nova lei trata justamente de alguns dos pontos abordados pela PGE em seu parecer e questionados pelo MPERJ, tais como: a possibilidade do empreendedor executar diretamente ou indiretamente esta obrigação e a legalidade de repasse desta obrigação a entidade conveniada com a SEA. Além disso, trouxe novidades de forma a promover maior transparência, como a obrigatoriedade de publicação anual do relatório de gestão e do balanço, bem como a divulgação em seu website do balanço dos recursos arrecadados e dos gastos já realizados. Contudo, deixou de abordar pontos centrais como, por exemplo, a possibilidade da entidade conveniada contratar outras empresas, utilizar parte destas verbas para ressarcir seus custos operacionais e a adoção das "taxas de administração".

\section{Conclusão}

O presente trabalho teve como objetivo estudar a compensação ambiental, iniciando-se pela análise dos fundamentos deste instituto, passando por sua evolução normativa para finalmente chegar aos questionamentos e polêmicas relativos à mesma. Tentou-se averiguar como estas questões têm interferido em sua aplicação prática de forma efetiva. Ressalte-se que este estudo não pretendeu esgotar e esmiuçar todas as 
questões controvertidas relacionadas à compensação ambiental, visto que seria tarefa quase impossível. O objetivo foi então apontar e analisar controvérsias consideradas atuais e relevantes com a esperança de contribuir para uma melhor e mais clara compreensão do tema nada simples em mãos, servindo como alerta do problema que enfrentamos atualmente e, principalmente, da urgência de que se chegue a uma solução definitiva e uniforme para que a compensação ambiental possa finalmente cumprir seu papel primordial de fortalecimento das unidades de conservação e, consequentemente, de promoção de um meio ambiente ecologicamente equilibrado. Neste sentido, veja-se abaixo, as considerações finais que podem ser extraídas do presente estudo:

1. O princípio da defesa do meio ambiente impõe que a ordem econômica brasileira deve buscar o equilíbrio entre a proteção ambiental e o desenvolvimento econômico. Para que se atinja a justiça social colimada pela ordem econômica constitucional é preciso pensar em desenvolvimento econômico com o uso adequado e racional dos recursos naturais. A compensação ambiental surge neste contexto representando uma busca pelo equilíbrio para restabelecer a ordem pública ambiental, evitando a socialização dos danos e impondo ao agente poluidor a obrigação de compensá-los.

2. O princípio do poluidor-pagador determina a internalização das externalidades ambientais negativas para que não ocorra a chamada privatização de lucros e socialização de perdas. Impõe-se, assim ao empreendedor todos os custos ambientais decorrentes do funcionamento de sua atividade, fazendo com que aquele que usufrua do bônus arque também com o ônus. $\mathrm{O}$ mesmo se apoia na teoria da compensação, já que aquele que utiliza para seu próprio proveito e se beneficia dos recursos ambientais, dado seu caráter difuso e esgotável, deverá arcar com o déficit imposto à coletividade.

3. A obrigação da compensação ambiental se efetiva no processo de licenciamento ambiental, sujeito à elaboração de EIA/RIMA, 
podendo causar danos juridicamente relevantes, porém toleráveis social e ecologicamente.

4. Nas situações em que a lei determinar forma específica de compensação poderá haver sua cumulação com medidas compensatórias específicas, desde que o impacto que for objeto destas não seja computado no cálculo da compensação ambiental, sob pena de ocorrência de bis in idem.

5. A ADI 3378-6, que teve por objeto o art. 36 da Lei do SNUC, não aprofundou o debate relacionado à sua natureza jurídica, tendo o Ministro Relator determinado que a compensação ambiental é uma "forma de compartilhamento de despesas com as medidas oficias de específica prevenção ante empreendimentos de significativo impacto ambiental", denominada "compartilhamento-compensação".

6. Restou decidido que a compensação ambiental é constitucional, mas a expressão "não pode ser inferior a meio por cento dos custos totais previstos para a implantação do empreendimento", constante do parágrafo $1^{\circ}$ do art. 36 da Lei do SNUC, é inconstitucional e que o valor a ser pago deve ser fixado proporcionalmente ao impacto ambiental.

7. Foram opostos Embargos de Declaração, visando esclarecer, principalmente, se o termo "percentual" foi ou não excluído do texto da lei e se a decisão se aplica ex nunc. Os referidos embargos, contudo, ainda esperam julgamento pelo STF.

8. Posteriormente ao julgamento da referida ADI, foi publicado o Decreto Federal 6.848/2009, determinando que se aplica o percentual máximo de $0,5 \%$ do valor do empreendimento para atingir o valor a ser pago. Isto implicou no ajuizamento da Reclamação 8465, alegando-se que o referido Decreto teria contrariado entendimento manifestado pelo STF na ADI 3376-8.

9. Foi travada discussão acerca da aplicabilidade da decisão da ADI e se a mesma já estaria operando efeitos jurídicos, visto que a mesma 
ainda não transitou em julgado. A questão principal que deve ser atentada, no entanto, não é a fixação de um limite, mas a possibilidade de se chegar a um valor zero, já que apenas estaria previsto um teto e não um piso. $\mathrm{O}$ perigo está em não se promover internalização alguma dos impactos não mitigáveis à biodiversidade.

10. Sobre a aplicação dos recursos da compensação ambiental na esfera federal, verificou-se através da auditoria operacional apresentada no Acórdão 1853/2013-TCU-Plenário, que os principais problemas que têm interferido na efetividade da aplicação destes recursos são justamente devidos às inúmeras alterações em sua normatização, bem como o ajuizamento da ADI 3378, dentre outros fatores como a precariedade nas ações de controle, incluindo a fiscalização e monitoramento, e a morosidade em sua valoração e destinação.

11. $\mathrm{Na}$ esfera estadual verificou-se, primeiramente, a falta de unanimidade nos Estados-membros em estabelecer uma base de cálculo uniforme da compensação ambiental, podendo implicar na inconstitucionalidade das normas estaduais que ampliam o escopo das normas federais, e a possível verificação de bis in idem em sua cobrança cumulada com a compensação ambiental social. Para que possa haver a cobrança cumulativa o órgão ambiental deverá desconsiderar os impactos no meio ambiente natural para proceder ao cálculo da compensação ambiental social e descontar os impactos sociais no cálculo da compensação ambiental.

12. Por fim, foi analisada a ACP recentemente ajuizada pelo MPERJ em face do FUNBIO, na qual foi alegada dupla dispensa de licitação, defendendo que a única forma legal de cumprimento da obrigação seria o pagamento em dinheiro pelo empreendedor ao órgão licenciador da quantidade calculada, em contrariedade ao Parecer 04/09-RTAM-PG-2 da PGE. Contudo, como foi visto, a questão principal que deve ser ventilada é qual é o melhor mecanismo, na prática, para que se garanta a máxima efetividade na aplicação dos 
recursos e, consequentemente, na manutenção das unidades de conservação, mesmo se isto significar dispensa de licitação e controle de contas pelo Tribunal de Contas do Estado. Os magistrados devem se atentar para o fato de que a suspensão das atividades do FUNBIO e o repasse desta gestão para o órgão ambiental pode não ser a melhor estratégia. De qualquer forma, deve-se aguardar o julgamento definitivo do processo para que seja analisada e averiguada a solução atingida.

13. A recém publicada Lei 6572/2013 do Estado do Rio de Janeiro dirimiu algumas das questões abordadas ao prever que o empreendedor pode executar diretamente ou indiretamente esta obrigação e que é legal o repasse da mesma para entidade conveniada com a SEA, como ocorre com o FUNBIO, além de promover maior transparência a gestão destes recursos.

14. Diante do exposto, resta inquestionável que o tema da compensação ambiental, apesar de prevista no ordenamento jurídico brasileiro há um tempo considerável, permanece atual e não está operando de forma satisfatória. A confusão normativa que se deu em relação a este instituto, bem como o ajuizamento das ações analisadas no STF, que já se prolongam há anos sem julgamento definitivo, fizeram com que o espírito da compensação ambiental não fosse atingido. Como se viu, estes acontecimentos, pelas dúvidas que geraram aos empreendedores e aos órgãos ambientais, acabaram gerando diversos entraves à sua aplicação prática de forma efetiva em âmbito federal e estadual.

15. O desafio atual é encontrar solução definitiva e uniforme para que se proceda ao cálculo da compensação ambiental. Apenas assim haverá segurança jurídica em relação ao funcionamento deste instituto, levando a uma aplicação mais rápida e eficiente destes recursos, fortalecendo de uma vez por todas as unidades de conservação em prol de um meio ambiente ecologicamente equilibrado. 


\section{Bibliografia}

ANTUNES, Paulo de Bessa. Direito Ambiental. 15 $5^{\mathrm{a}}$ Edição. São Paulo: Atlas, 2013. 1433p.

BECHARA, Erika. Licenciamento e Compensação Ambiental na Lei do

Sistema Nacional das Unidades de Conservação (SNUC). São Paulo: Editora Atlas, 2009. 295p.

BENJAMIN, Antonio Herman. O Princípio Poluidor-Pagador e a Reparação do Dano Ambiental. Disponível em: http://bdjur.stj.gov.br.

CAPPELLI, Silvia. Compensação Ambiental do Sistema Nacional de Unidades de Conservação: Considerações Pós-Decisção do STF na ADIn 3.378. In: MARQUES, Claudia; MEDAUAR, Odete; SILVA; Solange (Org.) O novo direito administrativo, ambiental e urbanístico: estudos em homenagem à Jacqueline Morand-Deviller. São Paulo: Editora Revista dos Tribunais, 2010

DERANI, Cristiane. Direito Ambiental Econômico. $3^{\mathrm{a}}$ Edição. Cidade: Editora Saraiva, 2008. 290p.

FERREIRA, Gabriel; SILVA, Solange. Análise dos Fundamentos da Compensação Ambiental: A Responsabilidade Civil Ex Ante no Direito Brasileiro: Revista de Informação Legislativa. Brasília, n. 175, p. 125 136, jul./set. 2007., n. 175, p. 125 - 136, jul./set. 2007.

FILHO, José dos Santos Carvalho. Manual de Direito Administrativo. $22^{\mathrm{a}}$ Ed. Rio de Janeiro: Editora Lumen Juris, 2009. 1181p.

FREITAS, Vladimir Passos de. Direito Administrativo e Meio Ambiente. $4^{\mathrm{a}}$ Edição. Curitiba: Juruá, 2010. 263p. 
MACIEL, Marcela Albuquerque. Compensação Ambiental. Instrumento para a implementação do Sistema Nacional de Unidades de Conservação. São Paulo: Letras Jurídicas, 2012. 237p.

MACHADO, Paulo Affonso Leme. Direito Ambiental Brasileiro. 21a Edição. São Paulo: Malheiros, 2013. 1311p.

MARCHESAN, Ana Maria Moreira; SEGURA, Sandra Santos; STEIGLEDER, Annelise Monteiro; PAGANELLA, Caros Roberto de Lima. Ação Civil Pública para Cumprimento da Compensação Ambiental. Revista de Direito Ambiental. São Paulo: Revista dos Tribunais, n. 57: p. $315,2010$.

MILARÉ, Édis; ARTIGAS, Priscila Santos. Compensação Ambiental: questões controvertidas. Revista de Direito Ambiental. São Paulo: Revista dos Tribunais, n. 43: 101-114, 2006.

MILARÉ Édis. Direito do Ambiente. $8^{\mathrm{a}}$ Edição. São Paulo: Revista dos Tribunais, 2013. 1614p.

MIRRA, Álvaro Luiz Valery. Impacto Ambiental. $4^{a}$ Edição. São Paulo: Editora Juarez de Oliveira, 2008. 182p.

MOREIRA, Danielle de Andrade. Princípio do Poluidor Pagador: Origens, Evolução e Alcance. In: SAMPAIO, Rômulo; LEAL, Guilherme; REIS, Antonio (Org.). Tópicos de Direito Ambiental: 30 anos da Política Nacional do Meio Ambiente. Rio de Janeiro: Editora Lumen Juris, 2011. p. 29-52.

MOREIRA, Danielle de Andrade. Responsabilidade Civil Por Danos Ambientais no Direito Brasileiro. Rio de Janeiro: Editora Lumen Juris, 2012. 
MOREIRA, Danielle de Andrade. Responsabilidade Ambiental PósConsumo: Prevenção e Reparação de Danos à Luz dos Princípio do Poluidor-Pagador. No prelo.

RODRIGUES, Marcelo Abelha. Aspectos Jurídicos da Compensação Ambiental. Revista de Direito Ambiental. São Paulo: Revista dos Tribunais, n. 46: 2007. 130-145, Disponível em: http://www.marceloabelha.com.br/site/publicacoes.php

RODRIGUES, Marcelo Abelha. Elementos do Direito Ambiental. $2^{\mathrm{a}}$ Edição. São Paulo: Revista dos Tribunais, 2005. 364p.

SILVA, José Afonso da. Direito Ambiental Constitucional. $8^{\mathrm{a}}$ ed. São Paulo: Malheiros, 2010. 351p.

SOARES, Sinara. As Inovações da Base de Cálculo da Compensação Ambiental da Lei do Sistema Nacional das Unidades de Conservação Decreto 6.848/2009. Revista de Direito Ambiental. São Paulo: Revista dos Tribunais, n. 69: p. 299, 2013.

\section{Websites:}

Acórdão n 1853/2013-TCU-Plenário:

Disponível em:

http://portal2.tcu.gov.br/portal/page/portal/TCU/imprensa/noticias/noticias arquivos/014.293-2012-9\%20(Compensacao\%20Ambiental).pdf. Acesso em 25.10.2013.

Demonstrações Financeiras 2012 FUNBIO:

Disponível em:

https://docs.google.com/file/d/0B155ih66QdFPM0UtQ0NjUDVZMms/edit 
?usp=sharing+https://docs.google.com/file/d/0B155ih66QdFPd0ZaZ2h6RX

NIUWM/edit?usp\%3Dsharing\&pli=1. Acesso em 27.10.2013.

Matéria jornalística O Globo:

Disponível em:

http://oglobo.globo.com/blogs/blogverde/posts/2011/05/19/em-lisboa-

minc-diz-que-brasil-esta-de-portas-abertas-investimentos-381383.asp.

Acesso em 27.10.2013.

Petição Inicial da ACP:

Disponível em: http://issuu.com/mp_araruama/docs/acp_funbio_2. Acesso em 27.10.2013.

Decisão da ACP:

Disponível em:

https://docs.google.com/file/d/0B155ih66QdFPUUtMeHI1ZXJ1VUU/edit? $\underline{\mathrm{usp}}=$ sharing \&pli=1. Acesso em 27 de outubro de 2013.

Recommendation of the Council on the Implementation of the Polluter-Pays Principle:

Disponível em:

http://acts.oecd.org/Instruments/ShowInstrumentView.aspx?InstrumentID= 11. Acesso em 15.08.2013.

Recommendation of the Council on a Comprehensive Waste Management Policy.

Disponível em:

http://acts.oecd.org/Instruments/ShowInstrumentView.aspx?InstrumentID= 14\&Lang=en\&Book=False. Acesso em 15.08.2013. 
Recommendation of the Council concerning the Application of the PolluterPays Principle to Accidental Pollution.

Disponível em:

http://acts.oecd.org/Instruments/ShowInstrumentView.aspx?InstrumentID=

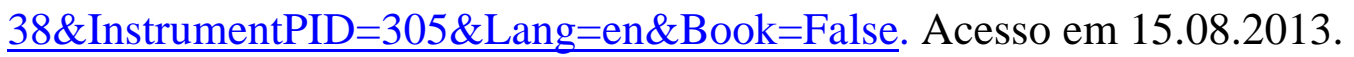

Recommendation of the Council on the Use of Economic Instruments in Environmental Policy. Disponível em:

http://acts.oecd.org/Instruments/ShowInstrumentView.aspx?InstrumentID= 41\&InstrumentPID=38\&Lang=en \&Book=False. Acesso em 15.08.2013.

Recommendation of the Council on the Use of Economic Instruments in Promoting the Conservation and Sustainable Use of Biodiversity.

Disponível em:

http://acts.oecd.org/Instruments/ShowInstrumentView.aspx?InstrumentID= 50\&Lang=en \&Book=False. Acesso em 15.08.2013.

Unidades de Conservação - ICMBio:

Disponível em:

http://www.icmbio.gov.br/portal/biodiversidade/unidades-de conservacao/biomas-brasileiros.html. Acesso em 22.10. 2013. 